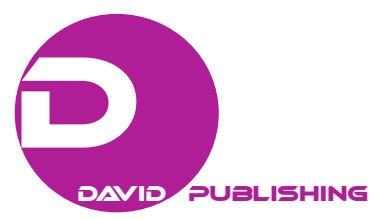

\title{
Giorgio Vasari's Last Supper: A Thanksgiving Celebration
}

\author{
Liana De Girolami Cheney \\ SIEALE, University of Coruna, Spain
}

For my parents Ettore Mosé Lombroso De Girolami, MD (1920-2005)

and Pina Gabriella Benedetta Quarta De Girolami (1920-2008)

\begin{abstract}
Among the numerous themes on the suppers cited in the Bible, the Last Supper of Christ with His twelve apostles is the most poignant and rewarding for Christianity. Florentine Renaissance depictions of the theme are numerous and varied, traditionally represented as a predella (step) panel and as an altarpiece in dining halls or sacristies of churches and convents. Vasari's Last Supper for the Refectory of Le Murate (The Walled) in Florence is an unusual depiction of Christ's thanksgiving. This imposing religious structure was painted for a poor Benedictine nunnery's cenacolo (refectory) in Florence. Vasari completed two drawings for the commission in 1546. The drawings and painting reveal how Vasari drew upon the work of his predecessors to create an innovative expression of thanksgiving, betrayal, and departure. This large masterpiece was severely damaged, almost irreparably, by several mishaps and floods in 1583 and 1718 and, more recently, by the major Florentine alluvione (flood) of 1966. In commemoration of the 50th year anniversary of this last catastrophic event, Vasari's Le Murate Last Supper was carefully and magically restored by a group of masterful technicians, artists, and scientists. Their collaboration and support from the private sector demonstrate the successful bond among art, technology, science, and patronage.
\end{abstract}

Keywords: cenacolo, Last Supper, convent, Christian symbolism, betrayal, thanksgiving, Giorgio Vasari, Florentine refectories, Le Murate

\section{Introduction}

\section{Hoc facite in mean commemorationen [Do this in remembrance of me]. ${ }^{1}$}

These words of Christ, proclaimed at the last meal with His apostles, impart and grant divine and human love to humankind. Giorgio Vasari (1511-46) visualized this historic moment in the Last Supper of 1546-47 for the refectory in the monastery of Le Murate (The Walled) in Florence (Figs. 1-3). ${ }^{2}$

Liana De Girolami Cheney, Ph.D., Visiting Scholar in Art History, SIEALE, University of Coruna, Spain.

Correspondence concerning this article should be addressed to Liana De Girolami Cheney.

${ }^{1}$ Rev. David Bauscher, The Original Aramaic New Testament in Plain English with Psalms \& Proverbs (8th ed. with notes) (Lulu.com: Glenn David Bauscher, 2013), hereafter cited as Aramaic Bible; and 1 Cor. 11:24.

${ }^{2}$ See Paola Deitz, "50 Years After the Flood," in The New York Times, Sunday, 6 November 2016, 18-21, an interview with Marco Grassi, Art Conservator in New York, about the restoration by the Florentine group led by Marco Ciatti, Director of the Opificio delle Pietre Dure (O.P.D.), a most modern restoration laboratory located in an old military warehouse. See Liana De Girolami Cheney, "Vasari and Naples: The Monteoliveto Order," in Papers in Art History, The Pennsylvania State University 5 (1994): 48-126. Roberto Bellucci, Marco Ciatti, and Cecilia Frosinini, Dall'alluvione alla rinascita: il restauro dell 'Ultima Cena di Giorgio Vasari (Florence: Edifir, forthcoming), on the masterful restoration of this 1966 alluvionato art work, will provide new archival documentation and new theories about Vasari's artistic composition as well information about the new techniques in restoration. My present essay went to print before this publication was published and available to me. 


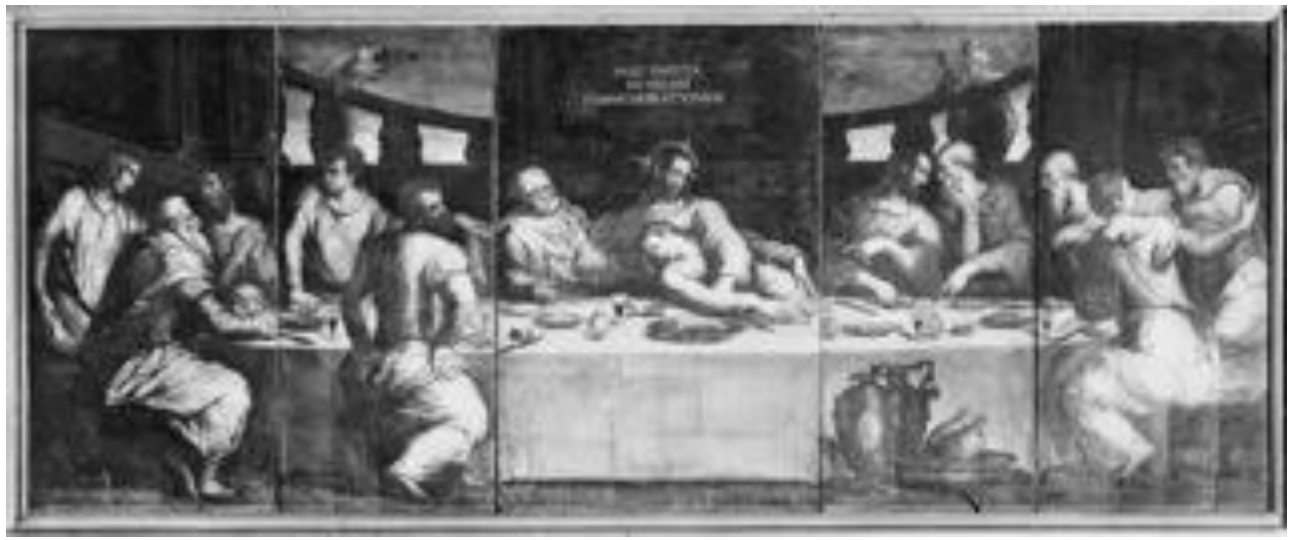

Figure 1a. Giorgio Vasari, Le Murate Last Supper, 1546-47. Santa Croce, Florence (before restoration). Photo credit: Brogi, c. 1920-30 -Alinari/Art Resource, NY.

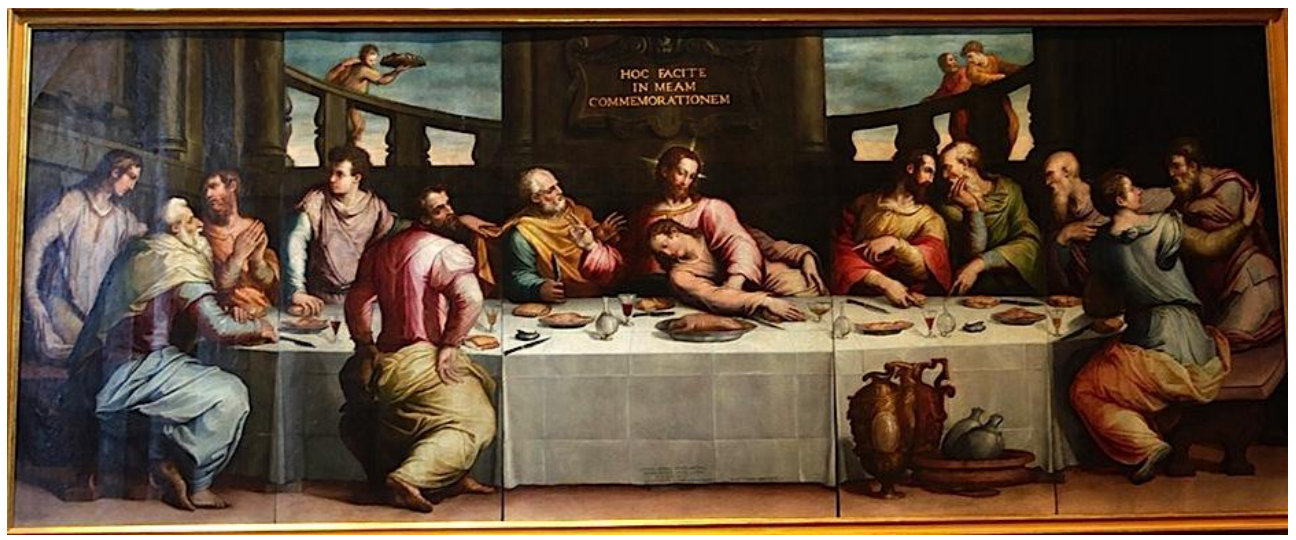

Figure 1b. Giorgio Vasari, Le Murate Last Supper, 1546-47. Santa Croce, Florence (after restoration). Photo credit: Prof. Yael Even.

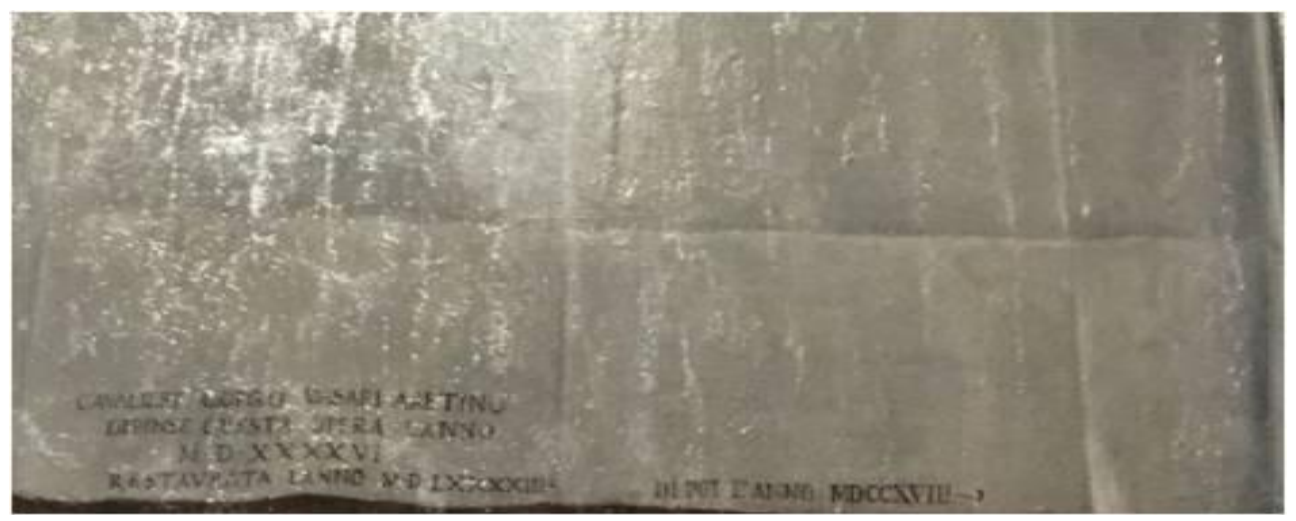

Figure 1c. Restorer's inscriptions in Giorgio Vasari, Le Murate Last Supper, 1546-47, Santa Croce, Florence. Photo credit: Prof. Yael Even. 


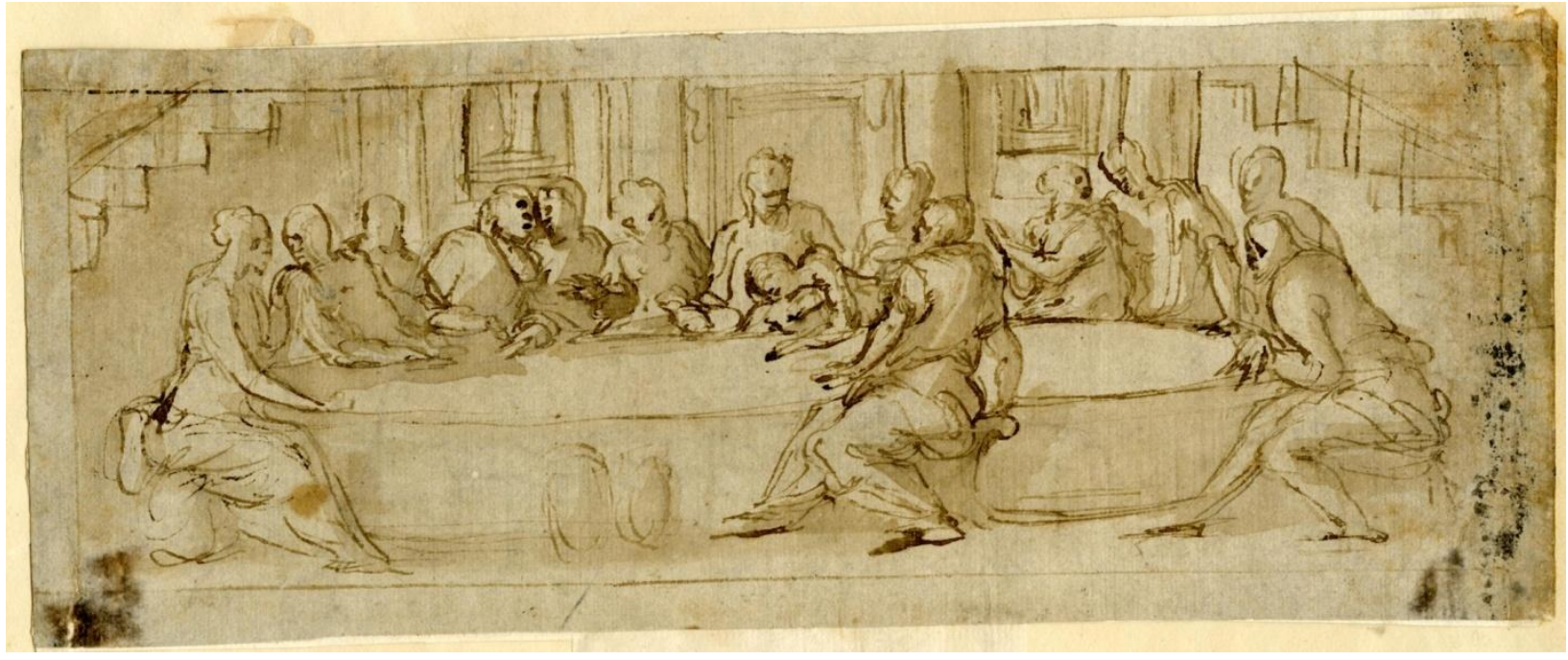

Figure 2. Giorgio Vasari, Last Supper, drawing, 1546, Inv. Sloane 5236-134. British Museum, London, England. Photo credit: British Museum, London, England.

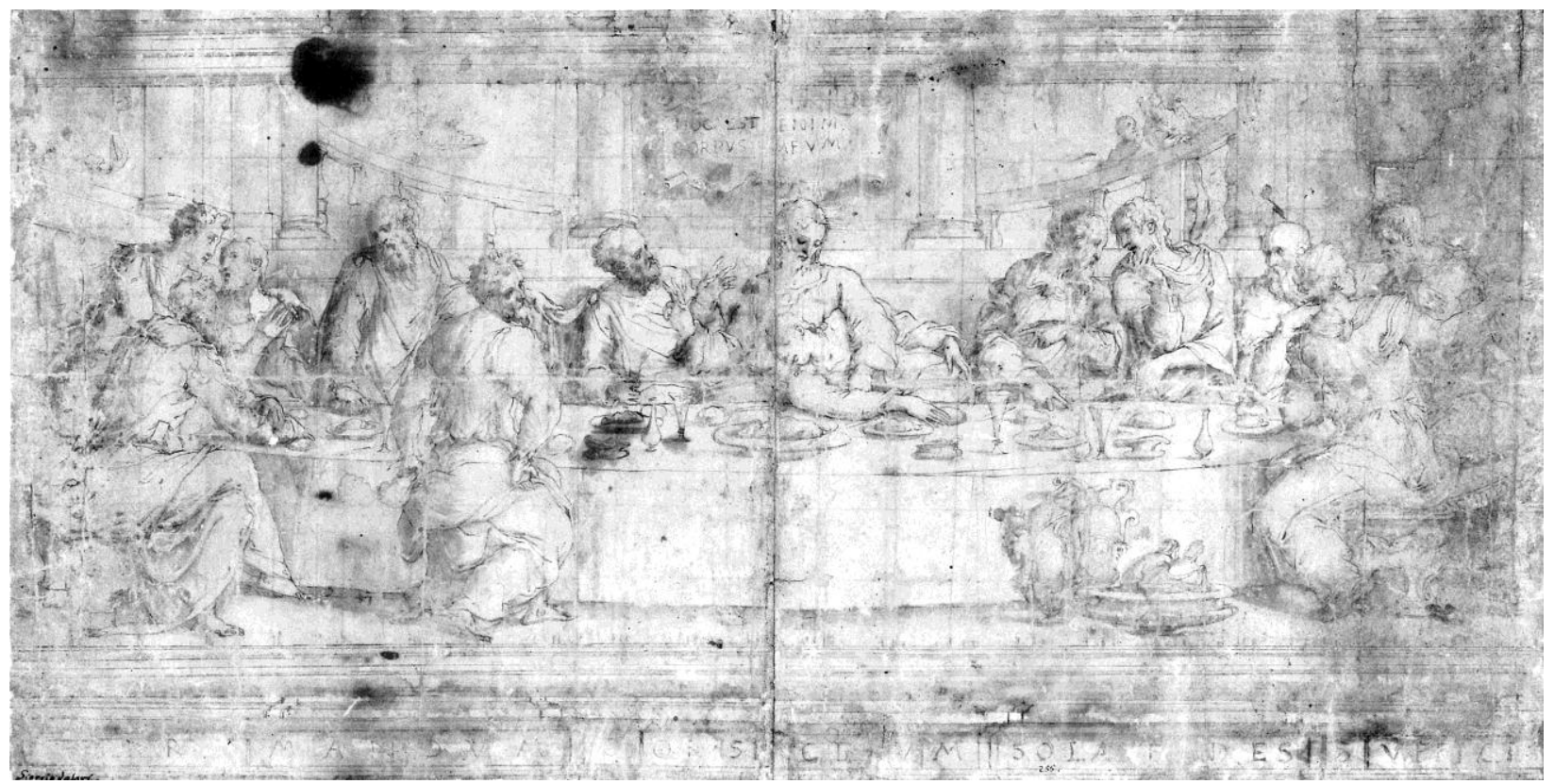

Figure 3. Giorgio Vasari, Last Supper, drawing, 1546, Inv. 2271. Staatliche Graphische Sammlung, Munich, Germany. Photo credit: Staatliche Graphische Sammlung, Munich, Germany.

In his Le Murate Last Supper, Vasari opened the religious drama with Hoc facite in mean commemorationen [Do this in remembrance of me], a Latin inscription in a large architectural cartouche-a tablet with an ornate scroll frame-located in the wall behind Christ and above His head. In a disegno [drawing] for the composition, located in the Staatliche Graphische Sammlung in Munich, Vasari opted for another version of Christ's words: Hoc est enim corpus meum [For this is my body]. The inscription reveals to the Christian viewer the meaning of the unfolding human and spiritual drama. According to the New Testament, these words were spoken after Christ had blessed and broken [the bread], saying, "Take eat; this is my body, 
which is broken for your persons; thus you shall do for my memorial." 3 To augment the historical and spiritual event, Vasari added in the Munich drawing another Latin thanksgiving inscription at the bottom of the scene or on rim of the frame: [AD] Firmandum cor sincerum sola fides svfficit [Faith alone is sufficient to fortify a sincere heart]. This inscription is no longer visible in the painting ${ }^{4}$ but only in the drawing. It derives from Thomas Aquinas's Eucharistic hymn Pange lingua gloriosi corporis mysterium [Sing, my tongue, on the mystery of the glorious Body]. ${ }^{5}$ Inventively, Vasari combined in these inscriptions, in both the drawing and the painting, references to two religious events: thanksgiving and departure. In addition, he visualized the event of the betrayal at the supper through the portrayal of the apostles' reactions after Christ's announcement: "Amen, I say to you, one of you will betray me" (Luke 22:21), ${ }^{6}$ which will cause his departure from His beloved

\footnotetext{
${ }^{3}$ From the Aramaic Bible (public domain). Roman Catholics refer to this event as a Last Supper; Protestants refer to it as the Lord's Supper; both traditions view the religious moment as a Passover, a Holy Communion, a Thanksgiving, and a Eucharistic celebration. The Last Supper, a final communion of Christ with His apostles in Jerusalem, is described in all four canonical Gospels (Matt. 26:17-30; Mark 14:12-26; Luke 22:739; and John 13:1-17). All citations from the Bible are taken from the American Standard Version (ASV) (public domain).

Mark 14:22-24: "And as they were eating, he took bread, and when he had blessed, he broke it, and gave to them, and said, 'Take ye: this is my body.' And he took a cup, and when he had given thanks, he gave to them: and they all drank of it. And he said unto them, "This is my blood of the covenant, which is poured out for many.",

Matt. 26:26-24: "And as they were eating, Jesus took bread, and blessed, and brake it; and he gave to the disciples, and said, 'Take, eat; this is my body.' And he took a cup, and gave thanks, and gave to them, saying, 'Drink ye all of it; for this is my blood of the covenant, which is poured out for many unto remission of sins."

Luke 22:19-20: "And he took bread, and when he had given thanks, he brake it, and gave to them, saying, 'This is my body which is given for you: this do in remembrance of me.' And the cup in like manner after supper, saying, 'This cup is the new covenant in my blood, even that which is poured out for you."'

Paul the Apostle followed Luke's testimony, hence noting:

1 Cor. 11:23-25: "For I received of the Lord that which also I delivered unto you, that the Lord Jesus in the night in which he was betrayed took bread; and when he had given thanks, he brake it, and said, 'This is my body, which is for you: this do in remembrance of me.' In like manner also the cup, after supper, saying, 'This cup is the new covenant in my blood: this do, as often as ye drink it, in remembrance of me."”

The Gospel of John does not include the bread and wine ritual. but scholars agree that John 6:58-59 alludes to the Eucharistic celebration and institutional wording (Aramaic Bible, public domain):

"This is the bread that came down from Heaven. It is not as your forefathers who ate manna and have died; whoever eats this bread shall live for eternity."

${ }^{4}$ See Richard Harpraph, "L'Ultima Cena," in Giorgio Vasari. Principi, letterati e artisti nelle carte di Giorgio Vasari. Pittura vasariana dal 1532 al 1554, ed. Laura Corti et al. (Florence: Edam, 1981), 63-64, for an interpretation on the removal of the lower inscriptions. He noted that after the last restoration of the painting in 1718, the convent was suppressed and Vasari's Last Supper was moved to the Cappella del Sacramento in Santa Croce. Perhaps then the lower Latin inscription was included in the frame of the painting or placed on the rim of the painting as seen in the Munich drawing. Two possible reasons may explain the disappearance of the inscription in the painting: a natural cause due to the flood of 1966; or dogmatic issues connected with beginning of the Reformation and the Council of Trent. This second inscription further focused on Christ's Eucharistic teaching being a probable cause of religious tension between the Florentines and Lutheran reformers.

5 This hymn was chanted during the processions of Maundy Thursday as well as during the Feast of Corpus Christi. Pange lingua translates into "Sing, my tongue on mystery of the glorious Body" or "Tell, my tongue on the mystery of the glorious Body." In the Gregorian chant, the hymn commences with
}

Of the glorious Body telling,

Oh my tongue, its mysteries sing,

and the Blood, all price excelling,

Which the world's eternal King,

In a noble womb once dwelling

Shed for the world's ransoming.

See Richard Harpraph, Italianische Zeichnungen des 16. Jahrhunderdts aus eigenem Besitz. (Munich: Staatliche Graphische Sammlung, 1977), 159-60. Harpraph was the first scholar to note the source for this Latin passage. See also Florian Härb, The Drawings of Giorgio Vasari (1511-1574) (Rome: Ugo Bozzi, 2015), 284-85, for recent literature on the Vasari's Le Murate Last Supper.

${ }^{6}$ From the Aramaic Bible (public domain): John 13:21; Matt. 26:21; Mark 14:17: “Amen, I say to you, one of you will betray me." 
apostles. $^{7}$

For the Munich drawing, Vasari designed this religious episode in two phases: one meditative and the other interactive. The meditative aspect is evoked by the inscribed Latin words reminding the devotees- the female members of the monastery - to contemplate Christ's thanksgiving; the interactive aspect engages the viewer in the historical moment during the supper when Christ announces that He will be betrayed and thereby provokes diverse reactions among His apostles. Vasari masterfully staged the event for the nuns of the convent so that they could ponder the human condition and Christ's message of forgiveness and love.

Before discussing the iconographical and iconological significations in Vasari's Le Murate Last Supper, the purpose of this study, I will briefly comment on the Christian components of the Last Supper and then consider the major Florentine representations of this event depicted during the Quattrocento (fourteenth century) and Cinquecento (fifteenth century). These accounts will demonstrate Vasari's artistic and cultural assimilation of the historical and religious traditions as well as his innovations in the creation of Le Murate Last Supper for the nunnery.

\section{Christian and Florentine Last Suppers}

The theme of the last supper derives from the classical tradition of sharing a festive banquet with family, friends, and important dignitaries. Biblical meals also take place among family and friends, and at times guests are invited. These meals take place in different settings and at different times of the day. The Christian supper, specifically, the Last Supper, follows in part the Old Testament rituals of the Passover Seder. ${ }^{8}$ It represents Christ's last meal with His twelve apostles. The meal of bread, wine, and pieces of lamb is offered at a table in an interior setting at dusk. ${ }^{9}$ These ingredients have specific Christian iconographical meanings: the bread is associated with Christ's body; the wine with Christ's blood; and the lamb symbolizes a sacrifice, Christ (Lamb of God) being crucified for human sins. ${ }^{10}$ After the gathering, Christ is taken by Roman soldiers to be interrogated, tried, judged, and killed. The twelve apostles who shared the meal with Christ are: Peter (Simon), Andrew (Peter's brother), Philip, Thaddeus, Simon, Bartholomew, James Minor, Thomas, Matthew (the tax collector), James Major (brother of John), John (the youngest apostles), and Judas Iscariot (Matthew 10:2).

Three levels of meanings are present in the Christian event. First is the announcement of the betrayal, which alludes to human limitations and weakness. For example, the apostle Judas Iscariot will identify Christ to the Roman soldiers after the supper so that the authorities can apprehend Christ and will receive compensation of 30 silver coins. Traditionally, Judas is depicted at the meal holding a moneybag. His behavior alludes to one of the seven deadly sins, greed, ${ }^{11}$ as well as his lack of faith in Christ as the Messiah, ${ }^{12}$ which violates God's

\footnotetext{
${ }^{7}$ See James Hall, Dictionary of Subjects and Symbols in Art (New York: Harper and Row, 1974), 188-92, for an art historical description of the Last Supper's episodes.

${ }^{8}$ See Brant Pitre, Jesus and the Last Supper (Grand Rapids, MI: William B. Eerdmans, 2015), 374-403, for a thorough discussion of the Last Supper as the New Passover.

9 See Pitre, Jesus and the Last Supper, 251-331, on the dating of the Last Supper and its historical background.

10 See Pitre, Jesus and the Last Supper, on bread, 406-411; on wine, 104-105, 108-109, 412-413; and on the lamb, 283-284, 290-292, 316-320. See also Gertrud Schiller, Iconography of Christian Art, 2 vols. (Greenwich, CT: New York Graphic Society, 1971), 2:117-121.

11 The seven deadly sins, capital vices or cardinal sins, are pride, greed, lust, gluttony, envy, sloth, and wrath; the virtues are humility, charity, chastity, temperance, kindness, diligence, and patience. See Shawn Tucker, The Virtues and Vices in the Arts: A Sourcebook, (Eugene, OR: Cascade, 2015); and Jennifer O'Reilly, Studies in The Iconography of The Virtues and Vices in the Middle Ages (New York: Garland, 1988).

12 See John 6:68, 11:16; Matt. 10:2-4; Mark 3:16-19; and Luke 6:14-16.
} 
first commandment: "You shall love the Lord your God with all your heart, and with all your soul, and with all your mind, and with all your strength" (Mark 12:28-31). ${ }^{13}$ The other type of betrayal is based not on lack of faith or greed but on fear and weakness, as in the case of the apostle Peter, who, after the supper and out of fear of incarceration and execution, will three times deny to the Roman authorities his association with Christ. ${ }^{14}$ Peter too failed to love God, but unlike Judas ${ }^{15}$ he immediately repented "after hearing the rooster crows," sadly remembering Christ's words, "you will deny me three times," hence, he "bitterly wept" (Luke 22:60-62). In the biblical story, the betrayal is a message of human despair.

The second level in the Last Supper is one of a thanksgiving celebration or a blessing of the meal, which includes offerings of bread and wine. This type of offering has a biblical prototype, whose earliest occurrence is in the Old Testament when Abel and Cain make sacrificial offerings to God (Gen. 4:3-5). ${ }^{16}$ In contrast to the meaning of the first level involving human betrayal, this second level, a mystical event, alludes to holy blessings, divine love, and forgiveness; it is a message of hope for humanity. The blessing of the meal institutes a tradition for Eucharist performances, which will be perpetuated and repeated at each offering of the mass. This is a beautiful message for humanity about redemption, resurrection, and eternal love.

The third theme alludes to Christ's dramatic departure from His beloved disciplines as well as from earth as the result of His Crucifixion. In the bleak moment of the Last Supper, Christ provided for His apostles hope and an eternal bond by reminding them to continue performing the Eucharist ritual: Hoc facite in mean commemorationen [Do this in remembrance of me], ${ }^{17}$ as depicted in Vasari's Le Murate Last Supper.

Numerous studies have discussed the importance of depictions of the Last Supper in cenacoli (dining halls or refectories) in Italian Renaissance art. This fascination is likely due to the expansion of religious orders and their patronage as well as the patronage of their devotees from families and members of municipalities residing in neighboring churches and convents. These investigations addressed in particular the historical subject of Christ's communion with His apostles, with the cenacolo functioning as a secular structure, a dining area, as well as a spiritual center for contemplation and prayers. ${ }^{18}$ The Italian word cenacolo combines two locus meanings: the eating of a meal at a traditional round table; and the place where the meal is served, such as a dining hall or refectory in a convent. Members of a religious order meet at certain times of the day to share their

\footnotetext{
13 A Jewish scribe asked Christ, "Which commandment is the first of all?" and Christ answered, "The first is, Hear, O Israel: the Lord our God, the Lord is one; you shall love the Lord your God with all your heart, and with all your soul, and with all your mind, and with all your strength." See Bible, New Revised Standard Version (NRSV, 1989) (public domain), Mark 12:28-31.

14 See Matt. 26:69-74; Mark 14:66-72; Luke 22:55-62; and John 18:15-18, 25-27.

15 The Scriptures have not revealed whether or not Judas repented and asked God's forgiveness before killing himself. Hence, historically, there is an assumption that he did not.

${ }^{16}$ See Bible, New International Version (NIV) (public domain), Gen. 4:3-5: "So it came about in the course of time that Cain brought an offering to the Lord of the fruit of the ground. Abel on his part also brought of the firstlings of his flock of the fat portions. And the Lord had regard for Abel and for his offerings, but for Cain and for his offering He had no regard. So Cain became very angry and his countenance fell."

17 See Aramaic Bible, 1 Cor. 11:24.

18 See G. Gilbert, "Last Suppers and their Refectories," in Charles Trinkaus, ed., The Pursuit of Holiness in Late Medieval and Renaissance Religion (Leiden: Brill, 1974), 371-402; C. Colds, "Queries on Last Suppers and their Refectories," in Trinkaus, The Pursuit of Holiness, 403-407; Luisa Vertova, I Cenacoli Fiorentini (Turin: Edizione Radiotelevisione Italiana, 1965); Philip Fehl, "Veronese's Decorum: Notes on The Marriage at Cana," in Mosche Barash et al., Art the Ape of Nature (New York: Harry H. Abrams, 1981), 341-365; Philipp Fehl, "Veronese and Inquisition: A Study on the Subject Matter of the So-Called Feast in the House of Levi, Files," in Gazette des Beaux-Arts 6, no. 158 (1961): 348-354; Federico Zeri, Ultima Cena of Leonardo da Vinci (Milan: Rizzoli, 1998); Lauretta Colonelli, trans. Michael Sullivan, The Table of the Lord: The Last Supper. What did Jesus and the Apostles Eat and What Have Painters Over the Centuries Given Them to Eat. Pictures, Recipes, Heaven and Hell (Florence: Edition Clichy, 2015); and Pitre, Jesus and the Last Supper, 121-147.
} 
meals. The conventional round table depicted in art will be transformed into the representations of an oval, $\mathrm{u}$-shape, and a rectangular format from the fourth century until the sixteenth. An analysis of the historical changes for these types of table formats is beyond the scope of this essay.

A few examples of Florentine representations of the Last Supper are briefly examined to illustrate the historical background against which Vasari's Last Suppers were conceived and to demonstrate the innovations in his Le Murate Last Supper. In the early Renaissance, many dining halls were graced with representations of the Last Supper, accompanied by other narrative scenes associated with the life of Christ or the patron saint of the religious order. For example, in the Franciscan refectory in the Basilica of Santa Croce in Florence, Taddeo Gaddi (1290-1366) painted the Tree of Jesse al fresco on the main wall, framing each side with episodes from the life of Saint Francis, while below them a large predella represents a Last Supper. This imposing fresco was completed between 1340 and 1345 (Fig. 4). ${ }^{19}$

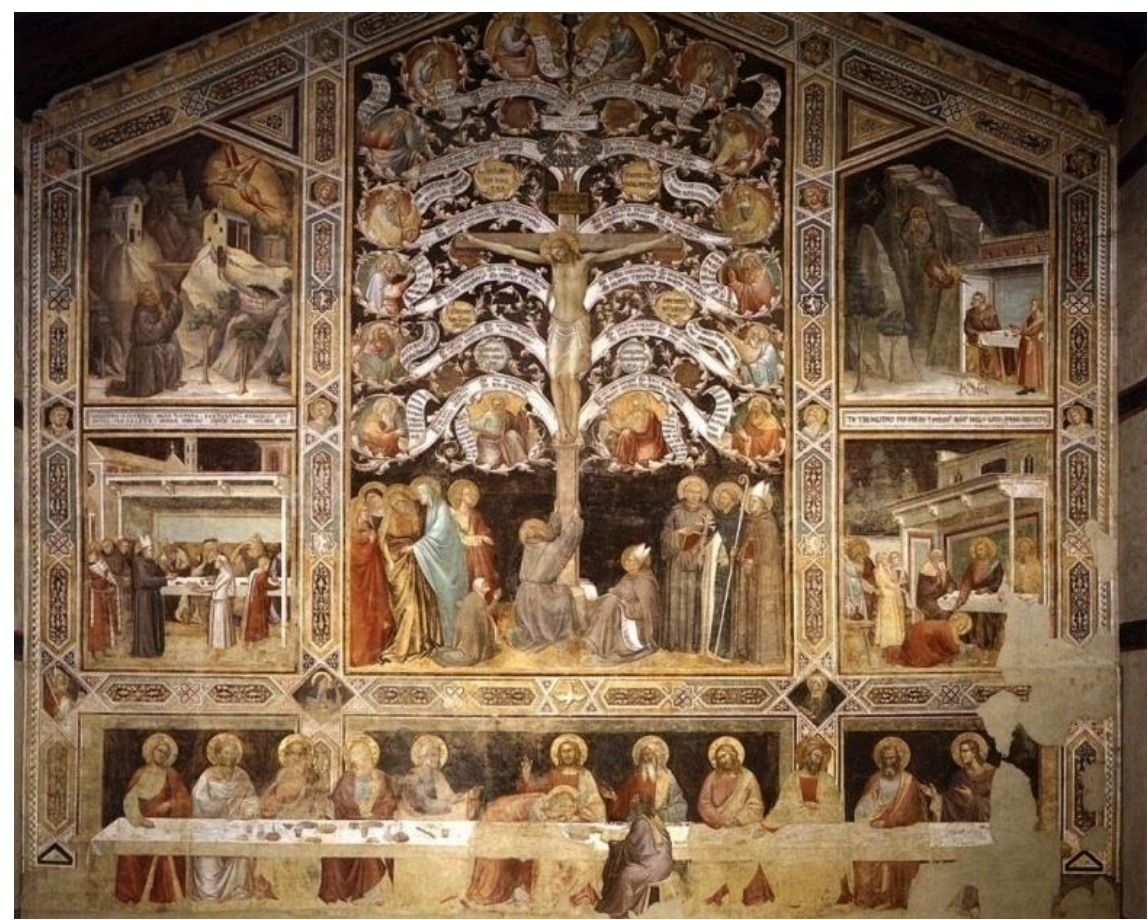

Figure 4. Taddeo Gaddi, Tree of Life, Four Miracle Scenes and Last Supper, 1340-45. Santa Croce, Florence. Photo credit: Public domain. Wikimedia.org.

In the Benedictine refectory of Sant'Apollonia, Andrea del Castagno (1423-57) depicted above his Last Supper different narrative scenes relating to the Passion of Christ, such as the Deposition, Resurrection, and Crucifixion. Castagno's Last Supper of 1447 takes place on an elaborate stage, where a perspectival interior is decorated with eccentric ornaments (Fig. 5). Pilasters with fish-scale motifs on the shafts and floral capitals frame the scene, while the bench upon which the apostles sit is composed of two lateral armchairs decorated with simulated statues of sphinxes resting on classical dadi. The dadi or cubical forms are decorated with a simulated relief containing a vessel or an urn. The Christian meanings of these elements are associated with Christ's human nature and divinity. The fish scales allude to the Christian symbolism of the fish as a reference

19 See Andrew Ladis, Taddeo Gaddi: Critical Reappraisal and Catalogue Raisonne (Saint Louis: University of Missouri Press, 1983), for a careful study on Gaddi's art. 
to the zodiac sign of Pisces, Christ's birth sign, and to the Christian meaning of the letters that compose Christ's name. In Greek, ichthus is a word for fish, which acrostically contains the name of Christ: (I) Christ (ch) God (th) Son (u) Savior (s). ${ }^{20}$ The sphinx not only guards the holy event but also, as an oracle, predicts Christ's life events, because she represents the beginning and the end of the zodiac cycle. ${ }^{21}$ Here the presence of the sphinx parallels Christ's announcement: "[I am] the Alpha and Omega, that is the Beginning and the End, the First and the Last" (Rev. 22:1.14). ${ }^{22}$ The urn is an ancient symbol of death in which the ashes of a deceased were preserved; and the vessel or vase carried wine, an offering ingredient in several portrayals of suppers, in particular the Last Supper. ${ }^{23}$

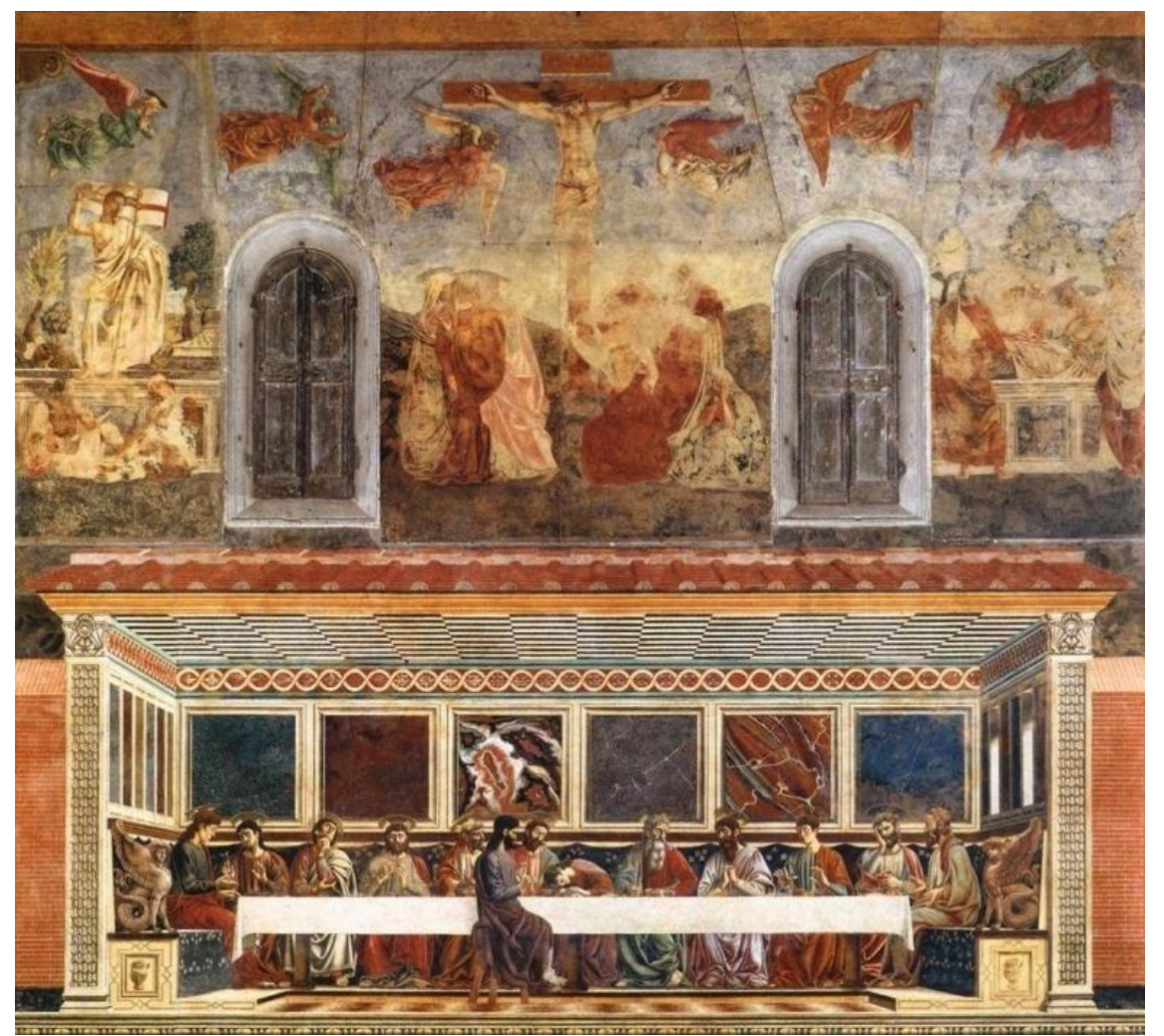

Figure 5. Andrea del Castagno, Last Supper, 1447. Santa Apollonia, Florence. Photo credit: Public domain. Wikipedia.org.

\footnotetext{
${ }^{20}$ See Matt. 4:19: "I will make you fishers of men." See also George Ferguson, Signs and Symbols in Christian Art (London: Oxford University Press, 1961), 18; Schiller, Iconography of Christian Art, 1:131 and 2:120, 122; Ralph F. Wilson, "Early Christian Symbols in the Catacombs," http://www.jesuswalk.com/christian-symbols/early-christian-symbols.htm (2006, accessed 2 January 2016); and A. Dunlop, Andrea del Castagno and the Limits of Painting (New York: Harvey Miller, 2015), for a recent study on Castagno.

${ }^{21}$ See A. Grabar, "Thrônes épiscopaux du XI et XIIe siècle en Italie méridionale," in Wallraf-Richartz Jahrbuch.16 (1954): 8-10; and Ann Wharton Epstein, "The Date and Significance of the Cathedral of Canosa in Apulia, South Italy," in Dumbarton Oaks Papers 37 (1983): 79-90, for a discussion about the throne at Canosa of 1080 as one of the first Italian sculptural monuments to represent sphinxes as guardians. This ancient motif is appropriated from heraldic sphinxes flanking the tree of life in Mesopotamian art, a variation on the lion as symbol of fortitude and guardianship. I am grateful to Prof. Liesbeth Grotenhius of Hanze University, Groningen (Netherlands), for these citations and suggestions. See also Helena Lehman, The Language of God in Prophecy (Elmwood Park, IL: Pillar of Enoch Ministry, 2006), chap. 6, 1-13, citation in 1, on the symbolism of the sphinx.

${ }^{22}$ For a complete citation, see Bible, King James Version (KJV, public domain), Rev. 22:1.14: “'And behold, I am coming quickly, and My reward is with Me, to give to every one according to his work. I am the Alpha and the Omega, the Beginning and the End, the First and the Last.' Blessed are those who do His commandments, that they may have the right to the tree of life."

${ }^{23}$ See Ferguson, Signs and Symbols in Christian Art, 167-178.
} 
Unlike Gaddi's placement of Judas across from Christ, facing him from right to left, Castagno switches Judas to face Christ from left to right. He further switches the placement of the young apostle John from Christ's right side to His left side. In Italian Renaissance Last Supper paintings, the placement of John and Judas varies through the centuries and from painter to painter: sometimes John is seated on the left or right side of Christ; while Judas most of the time is separated from the other apostles by being placed on the other side of the table; sometime he is facing Christ from His left or on right side. Discussions about the historical changes in the apostles' seating arrangements due to religious reforms and theological creeds are excluded from this essay.

Domenico Tommaso di Bigordi called Ghirlandaio (1449-94) painted al fresco several Last Suppers: in 1480 for the refectory of the Church of Ognissanti (Fig. 6); ${ }^{24}$ and in 1482 for the refectory of the Church of San Marco (Fig. 7). ${ }^{25}$

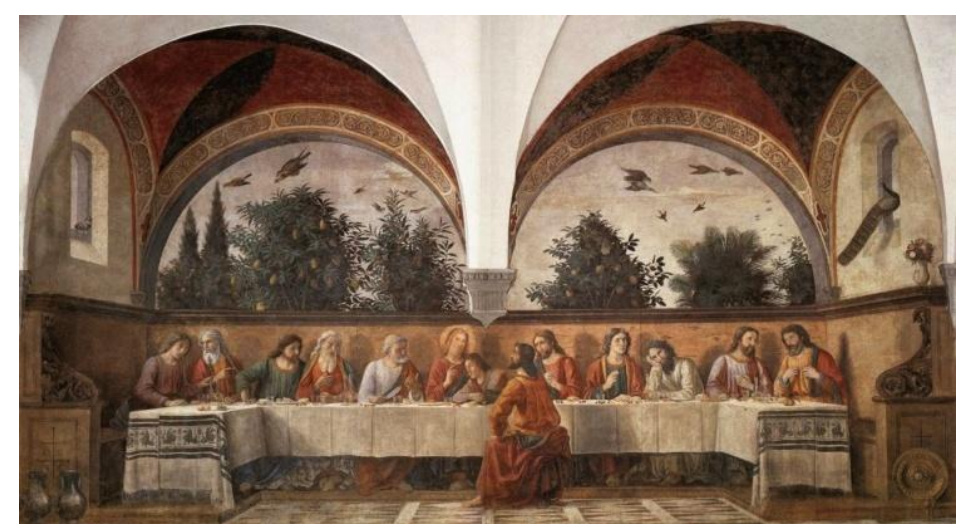

Figure 6. Domenico Ghirlandaio, Last Supper, 1480. Church of Ognissanti, Florence. Photo credit: Public domain. Wikipedia.org.

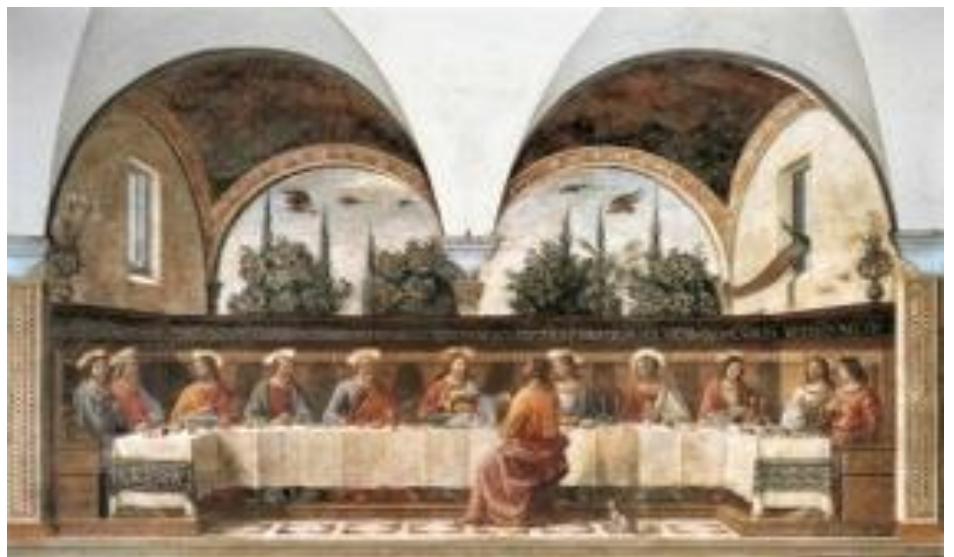

Figure 7. Domenico Ghirlandaio, Last Supper, 1482. Church of San Marco, Florence. Photo credit: Liana De Girolami Cheney.

\footnotetext{
${ }^{24}$ The Church of Ognissanti was founded by the Umiliati order in 1251. Later the Cistercians joined this order. Families residing around the church's area commissioned works of art for the convent; for example, the Vespucci family sponsored the sinopia and fresco painting of Ghirlandaio's Last Supper. Domenico Ghirlandaio and his brother David (1452-1525) also painted a Madonna della Misericordia fresco in Ognissanti's Vespucci chapel. See Jean K. Cadogan, Domenico Ghirlandaio (New Haven: Yale University Press, 2001), for a comprehensive study on this painter.

${ }^{25}$ In the twelfth century, a religious complex of church and convent of the Vallombrosan order was founded. Later the convent became a Benedictine monastery. In 1435 it was affiliated with the Dominican order under the patronage of Cosimo I de' Medici the Elder. Today it is part of the Convent of San Marco in Florence.
} 
Unlike Castagno, Ghirlandaio referred to the religious drama of the Passion and Redemption of Christ by employing decorative motifs such as evergreen plants, quails in flight, fruits (oranges and cherries), the dove, and the peacock. ${ }^{26}$ Both of Ghirlandaio's scenes focus solely on the meal celebration within an interior setting where open arcades show the Tuscan countryside. The apostles' grouping and their reactions are similar in both versions, with minimal differences in their composition and decoration. Variants include the type of landscape scenes viewed through the arcades, the number and selection of birds and domestic objects, and the table settings. In the Ognissanti Last Supper, Ghirlandaio assimilated Castagno's sphinx design, decorating the edge of each side of the tablecloth with a band motif of sphinxes facing each other. Each end of the banquette is decorated with a type of Lorraine cross with Christ's principle of Alpha and Omega inserted. In such ways, Ghirlandaio discreetly appropriated Castagno's symbolism about beginning and end. In Ghirlandaio's San Marco fresco, the Latin inscription in the lintel area above the apostles' head recalls one glorious moment of the Last Supper: Ego dispono vobis diseposuit mihi pater meus regnum ut edatis et bibatis super mensa meam in regno meo [I bestow on you a kingdom, just as My Father bestowed one on Me] (Luke 22:29-30). Also in the San Marco fresco, the symbolism of Judas as evil is reinforced by the inclusion of a cat behind him. ${ }^{27}$

The Gaddi and Ghirlandaio Last Suppers depict the banquet taking place in a dining hall at a u-shaped table around which the twelve apostles sit. Christ is always seated at the center of the table in a place of honor, and Judas is usually seated across, facing Him from the right or from the left and separated from the other apostles, while John is usually seated on the right side of Christ. But Castagno changes this formula: Judas sits across from Christ, facing from the right, and John is seated at Christ's left side. This seating arrangement indicates to the viewer that Castagno wanted to portray Judas as outcast from the group.

In 1498, the Florentine Leonardo da Vinci (1452-1510) painted the most inventive Last Supper of the Renaissance for the Dominican refectory of Church of Santa Maria delle Grazie in Milan (Fig. 8). ${ }^{28}$

\footnotetext{
${ }^{26}$ See Ferguson, Signs and Symbols in Christian Art, for the symbolism of virtues, such as immortality, seen in the evergreen plants, 24-33, and peacock, 23; for the symbolism of love, seen in quails, 23; for the symbolism of peace, seen in doves, 15; for the symbolism of generosity, seen in fruits, oranges, 35, and for the symbolism of kindness, seen in cherries, 15. In the Bible, New International Version (NIV, public domain), the quails are associated with the Old Testament story of The Fall of Manna when Moses, following God's instructions, noted that in the evening "quails came and covered the [Israelite] camp with layers of dew" and in the morning the dew became bread (Exod. 16:15).

27 See Ferguson, Signs and Symbols in Christian Art, 14.

28 "Leonardo imagined, and has succeeded in expressing, the desire that has entered the minds of the apostles to know who is betraying their Master. So in the face of each one may be seen love, fear, indignation, or grief at not being able to understand the meaning of Christ; and this excites no less astonishment than the obstinate hatred and treachery to be seen in Judas." See Rosanna Bettarini and Paola Barocchi, Giorgio Vasari, Le vite de più eccellenti pittori, scultori e architettori: nelle redazioni del 1550 e 1568, 6 vols. (Florence: Sansoni, 1996-1998) (hereafter cited as Bettarini-Barocchi, Vite), 4:26; and Leo Steinberg, Leonardo's Incessant Last Supper (New York: Zone, 2001), originally printed in The Art Quarterly 36, no. 4 (1973): 297-410, for a perceptive interpretation about this painting.
} 


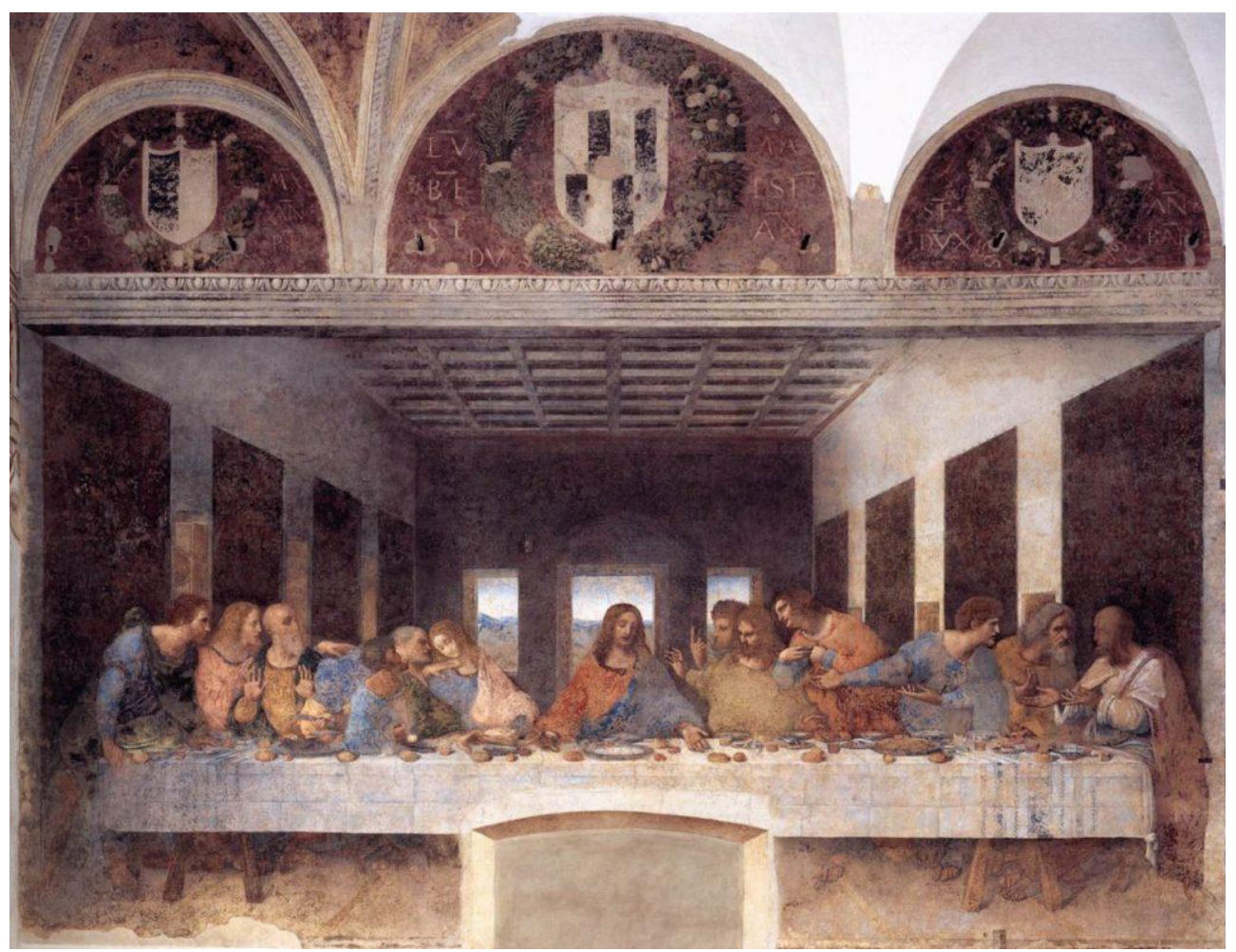

Figure 8. Leonardo da Vinci, Last Supper, 1498. Refectory, Santa Maria delle Grazie, Milan. Photo credit: Public domain. Wikimedia Commons.

He depicted this religious event with a remarkable composition framed with a classical decoration and containing in the lintel an Ionic architrave and egg-dart motifs. Masterfully, the classical frame creates a perspectival illusion of moving the faithful or viewer from an exterior secular space (the wall of the hall) into an interior religious space (the painting), hence transferring the experience of the religious theme from the external natural world into an internal spiritual world. The painting design is composed by geometrical forms and arithmetic variances: the twelve apostles are arranged in four groups of clusters of three apostles, echoing the geometrical number three of the three open windows in the background. These types of geometrical and numerical forms are associated with Christian symbolism. ${ }^{29}$ Christ in the center of the composition, for example, fits into an isosceles triangle, a perfect form from the union of three lines, a Trinitarian symbol. Although the iconography follows the traditional Passover Seder, a thanksgiving meal, ${ }^{30}$ Leonardo monumentalized the drama in depicting a beautiful decorated room with hanging embroidered tapestries, four of them on each side of the walls; and three windows opening into a celestial landscape. However, in the interpretation of the religious story, through the apostles, Leonardo unveils human failures, frailties, fears, and incapacity for love. Historically, Leonardo depicted the moment in which Christ uttered the words, "One of you

\footnotetext{
${ }^{29}$ See Robert D. Johnston, Numbers in the Bible: God's Unique Design in Biblical Numbers (Grand Rapids, MI: Kregel, 1999); E.W. Bullinger, Numbers in Scripture: Its Supernatural Design and Spiritual Significance (Grand Rapids, MI: Kregel, 2011, repr. of 1894 and 1921); and Michael Hunt, The Significance of Numbers in Scripture (May 2012), http://www.agapebiblestudy.com/documents/the\%20-significance\%20of\%20numbers\%20in\%20scripture.htm (accessed 2 January 2016). In the application of numerical and geometrical configurations to artistic forms, Leonardo may have applied Dante's Pythagorean symbolism and numerical method employed in the poema sacro (Divine Comedy). On this topic, see P. Vinassa De Regny, Dante e il simbolismo pitagorico (Genoa: Fratelli Melita, 1988).

30 See Pitre, Jesus and the Last Supper, 340-345, on the feast of the Passover; 438-443, on the difference between Eucharist and Passover.
} 
will betray me" (Matt. 26). In a spontaneous state of shock, His apostles abruptly react. One in particular, Judas of Iscariot, backs away from the table and clutches onto his moneybag, a pitiful reward for identifying Christ to the Roman authorities after the thanksgiving meal. In the painting, Judas daringly looks at Christ, wondering how the Master is aware of the betrayal. Judas's ill-fated action is contrasted with Peter's proud and bellicose act of defiance as he raises a knife from the table. Although this is an act of defiance and defense, eventually he too will betray Christ after this meal. Ingeniously, Leonardo, unlike his artistic predecessors, did not separate Judas from the other apostles. He elaborated on their reactions as seen in Judas holding with his right hand a pouch, symbol of his greed and betrayal, while John does not faint in the arms of Christ, as in previous Florentine compositions, but buffers Peter's aggressive reaction and Judas's cowardly gesture by calmingly clasping his hands. ${ }^{31}$ It is through John's peaceful action, a symbol of fides simulacrum [an image of faith] ${ }^{32}$ that Leonardo conveys the affirmation (fides) of Christ's message of forgiveness and love, hence restoring in the Last Supper a message of faith and hope for Christian faithful viewers.

For the Tertiary Franciscan order of Sant'Onofrio of Fuligno in Florence, Pietro Vannucci Perugino (1446-1523) painted in the refectory a Last Supper in 1493-96 (Fig. 9). Since 1419, the convent of Fuligno housed the Clarissian nuns (Poor Clares order or Order of Saint Claire). Later this nunnery became a convent and school for noble and poor Florentine girls, receiving patronage from Lorenzo de' Medici when his daughter attended the school.

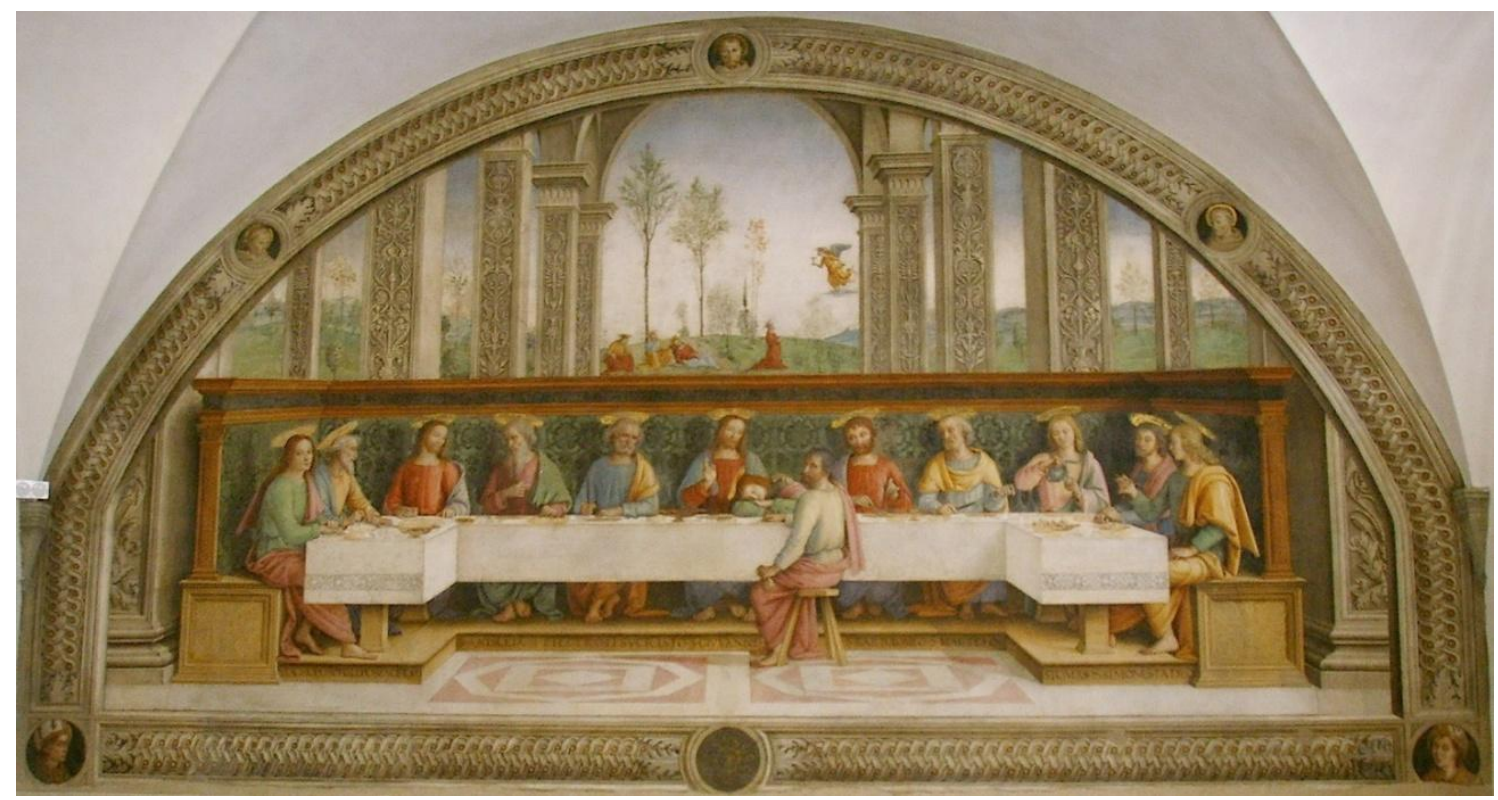

Figure 9. Perugino, Last Supper, 1493. Sant'Onofrio of Fuligno, Florence. Photo credit: Public domain. Wikipedia.org.

Perugino's Last Supper is similar in composition to the second version of Ghirlandaio's Last Supper. The main difference is the background with an elaborate architecture constructed of classical pillars forming a

\footnotetext{
31 See Steinberg, Leonardo's Incessant Last Supper, 297-410.

32 See Guy de Tervarent, Attributs et Symboles dans L'Art Profane (Geneva: Droz, 1997), 307, on the joining of hands as alluding to faith and trust to the given word; and Roberto Weiss, "A Note on the so-called 'Fides Simulacrum," Journal of the Warburg and Courtauld Institutes 24 (1961), 128. In emblematic literature, the clasped hands symbolize Concordia (harmony with one heart) and Peace. See Andrea Alciato, Emblematun liber (Augsburg: Heinrich Steyner, 1531), emblem on Concordia.
} 
fictive nave of a church in an open Tuscan or Umbrian landscape. The extensive landscape contains a central scene representing Christ praying in the Garden of Olives or Gethsemane, referring to Christ's Agony in the Garden (Luke 22:43-44). During this painful episode an angel appears from heaven to comfort Him by bringing Him a chalice as a remembrance of His purpose on earth: instituting thanksgiving (Eucharist), forgiveness, and salvation through His spilled blood in the Crucifixion (Matt. 26:42). A small vignette in the painting shows three apostles-Peter, John, and James-who have fallen asleep during Christ's hour of agony; they are unaware of the miraculous apparition of the angel with a chalice to console Christ. In his Last Supper, to clarify the identity of the apostles, Perugino inscribed their names on the wooden edge of the dining platform. The elaborate round arch, composed of fictive interlaced cosmati tresses, frames the religious scene. Six medallions with five portraits of members of Franciscan order are inserted in the arch while the sixth one, located in a direct axis to Christ, contains a monograph with the initials of Christ, IHS, surrounded by a flaming sun; this is the insignia of the Franciscans, whose order is being honored. ${ }^{33}$

In the Florentine Cinquecento, representations of the Last Supper appear, but less frequently. One example is that of Francesco di Cristofano called Franciabigio (Francia Bigio, 1482-1525), commissioned by the Abbess Antonia de' Medici in $1514 .{ }^{34}$ She was the superior of the Dames of Malta, the female branch of the Sovereign Military Hospitalet Order of Saint John of Jerusalem and of Malta. ${ }^{35}$

Franciabigio's refectory was located in the Church Hospital of Saint John the Baptist (Fig. 10). The interior setting he depicted is similar to that in Ghirlandaio's San Marco Last Supper, although he limits the visibility of the outside world by including three windows with large shutters. Visible through the central window is the old Florentine city wall with the now-destroyed gate of San Pier Gattolino. Through the left window, the area of the Boboli Gardens and Poggio Imperiale can be recognized. The third open window shows a cityscape and two doves placed on the edge of the window, augmenting the perspectival illusion.

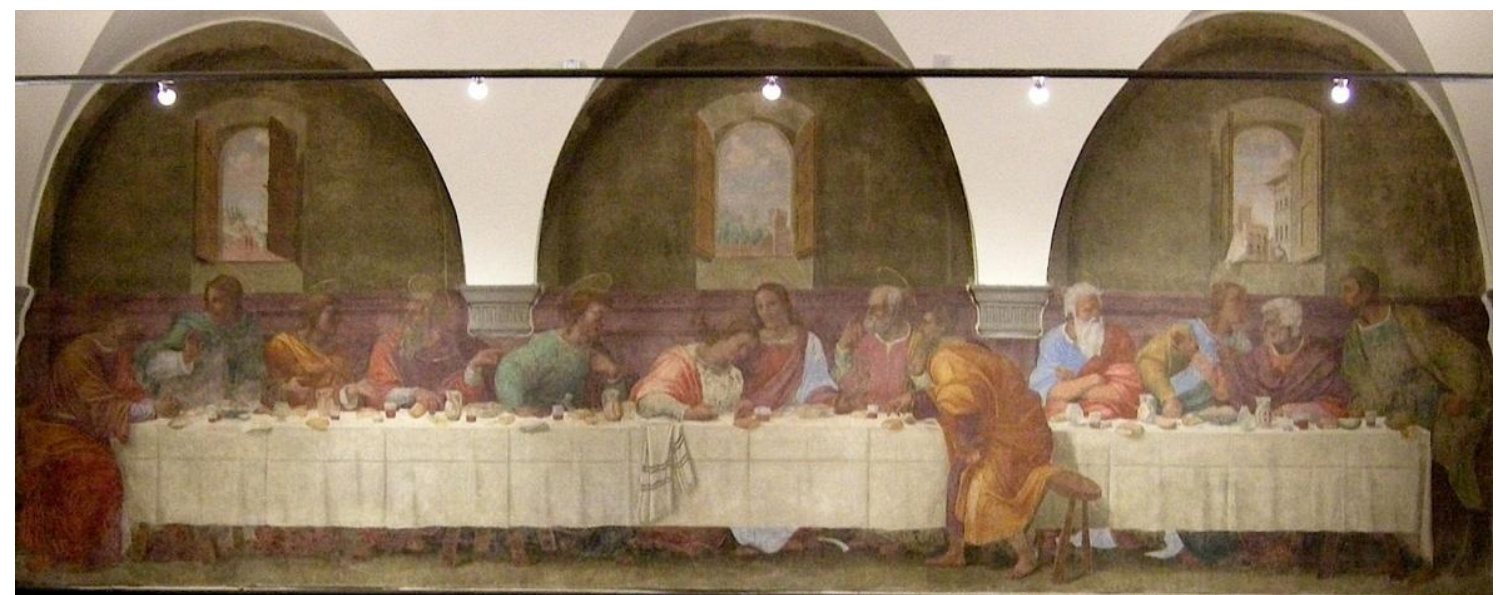

Figure 10. Franciabigio, Last Supper, 1517. Cenacolo della Calza, Florence. Photo credit: Public domain. Wikipedia.org. Photographer Saiko.

\footnotetext{
${ }^{33}$ See A. Tartuferi, and F. D'Arelli, L'Arte di Francesco: Capolavori d'arte italiana e terre d'Asia, dal XIII al XV secolo (Milan: Giunti, 2014).

${ }^{34}$ Giorgio Vasari described in the vita of Francia Bigio (Franciabigio) that "he was very keen on studies of perspective and human anatomy, as you can tell by the accurate position of the wooden shutters painted along the wall." Bettarini-Barocchi, Vite, 4:506.

${ }^{35}$ Later owned by Convitto della Calza (Convent of the Sock).
} 
Following artistic tradition, the names of the apostles are painted along the lintel that runs above their head. But Judas is additionally noted by his outburst in reaction to Christ's words about the betrayal. Jumping up from his stool, which is tilting, and launching his body toward Christ, Judas is hauntingly identified, while the other apostles sit agitated at the table. Franciabigio distinguished himself from other Florentine painters of Last Suppers by including different items at the table, e.g., the food displayed in the meal includes such things as cantaloupes and other exotic fruits not commonly included in traditional paintings of the subject. ${ }^{36}$ Perhaps the cantaloupes are an allusion to the Middle Eastern travels of the Cavalieri of Malta, since this fruit was popular in that area. Furthermore, some pitchers of wine are designed with the Medici coat of arms, while others are decorated with the insignia of the Maltese Cross, a white cross on a red background, alluding to Order of the Knights of Malta. Both decorations connect with the family and role of the Abbess Antonia de' Medici, whose family of origin were the Medici, as well as her governance as a mother superior of the Order of the Dames of Malta. To honor the abbess's commission, Franciabigio painted her initials SVORA AN, referring to Superior Antonia, in the left side of the floor between the second and third apostles. He also dated and signed the fresco painting as A(nno) S(alutis) MDXIIII [1514] with his initials (FRANC) in a twisted monograph, on the legs of the table, underneath the seated apostle Philip.

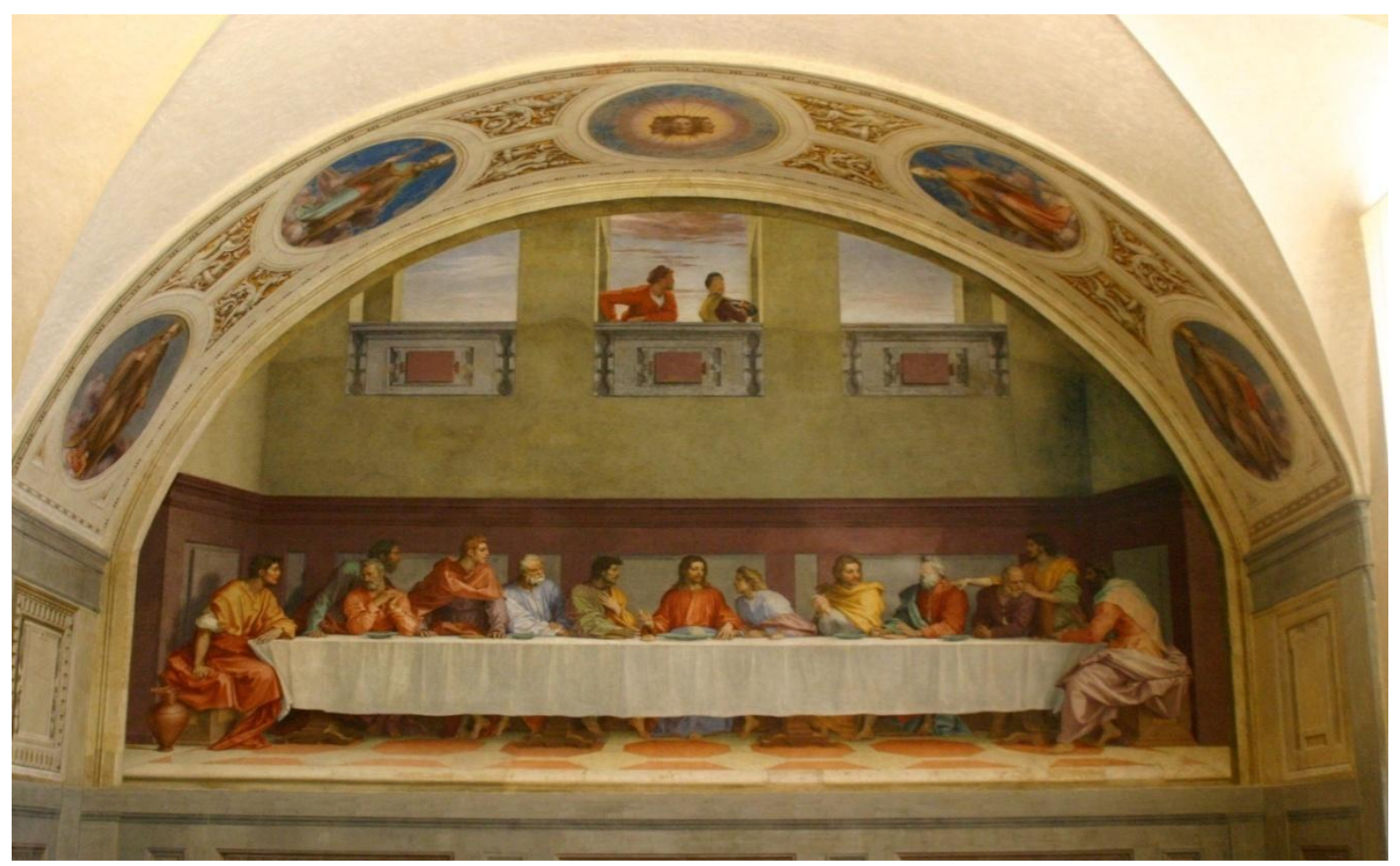

Figure 11. Andrea del Sarto, Last Supper, 1525-27. Convent, San Michele at San Salvi, Florence. Photo credit: Public domain. Wikipedia Commons.

${ }^{36}$ See Colonelli and Sullivan, The Table of the Lord, passim. 
Between 1525 and 1527, Andrea d'Agnolo di Luca di Paolo del Migliore, known as Andrea del Sarto (1485-1530), painted a most moving interpretation of the Last Supper for the monastery dedicated to Saint Michael in San Salvi from the order of the Vallombrosan (Fig. 11). ${ }^{37}$

Under the influence of Leonardo and Raphael (compare Figs. 13-16), ${ }^{38}$ del Sarto adroitly aggrandized the moment of the betrayal by depicting Judas seated on the right side of Christ, raising his hand to his chest in response to Christ having just uttered: “'Verily I say unto you, that one of you shall betray me,' and [Judas] the traitor [inquired] and he asked, 'It is I, Rabbi?' [Jesus] responded to him, 'You have said.",39 Judas is further perturbed by Christ's further action in offering him a piece of the blessed bread. Understanding human suffering and wishing to convey this sentiment in the painting, del Sarto depicted Christ's human nature. In the painting, at the same time He acknowledges Judas's betrayal, Christ turns toward His favorite apostle John for human comfort and reaches out to caress his hand. This is perhaps one of the most human, loving, and tender gestures of Christ depicted in any Florentine Last Supper. Del Sarto focused mostly on the offering of the bread; no chalice or wine glasses are visible on the table. As Matthew recorded (26:22-24): "And as they were eating, Jesus took bread, and blessed, and broke it; and he gave to the apostles, and said, 'Take, eat; this is my body.",40 The simplicity of the architectural decoration of the dining hall is contrasted with the majestic representation of Christ's loving behavior. Three open arches are depicted above the dining area, the center one depicting an alcove with two figures attending to the meal. One figure wears a painter's outfit and beret, suggesting a self-portrait of the artist. Above them, in the sky, a splash of pink color alludes to the time of day: sunset. With this celestial imaging, del Sarto continued to portray Christ's message of hope, imparted during the thanksgiving meal.

\footnotetext{
37 In 1534, the convent became a nunnery in clausura until the nineteenth century. In the archway of the refectory above the Last Supper, del Sarto painted large medallions with depictions of the Vallombrosan monks: SS Giovanni, Gualberto, Salvi, Bernard Uberti, and Benedict. The central medallion above the Head of Christ depicts three heads symbolic of the Trinity (Trifrons).

38 Before residing in Rome, Raphael lived in Florence from 1504 to 1508. In Rome between 1510 and 1516, Raphael completed two compositions on the Last Supper, which were popularized through Marcantonio Raimondi's engravings (Figs. 12 and 13). See Marcantonio Raimondi, drawing after Raphael's Last Supper of 1515-1516, at the Victoria and Albert Museum, London (Bequeathed by Rev. Alexander Dyce, DYCE. 1007, Fig. 14). Raphael's Last Supper composition of 1516 derives from Leonardo's painting, and both were influential for Andrea del Sarto in terms of composition design of a Renaissance setting with a rectangular table and the treatment of the apostles such as the placement of Judas next to Christ. Raphael's earlier Last Supper of 1510 for the Loggia Vaticana of the Palazzi Pontifici at the Vatican derives from another Dürer's Last Supper, a woodcut of 1510 at the Albertina Museum in Vienna (compare Figs. 13 and 16). Interestingly, Raimondi had also composed an engraving after Dürer's woodcut in 1512 (Metropolitan Museum of Art, NY, Gift of Henry Walters, 1917 Accession Number 17.37.243; compare Figs. 14 and 15). See Bettarini-Barocchi, Vite, 4:189-190, for a description of the relationship between Raphael and Dürer as well as Raphael's collaboration with the printmaker Marcantonio Raimondi. See also Bettarini-Barocchi, Vite, 5:6-7, on Raimondi and Dürer; and Robert H. Getscher, An Annotated and Illustrated Version of Giorgio Vasari's History of Italian and Northern Prints from His Lives of the Artists (1550 and 1568) (New York: Mellen, 2003), 151-161, for a thorough study on the relationship between Dürer and Raimondi; and 161-183, for an examination of Raimondi's prints after Raphael.

39 On Betrayal, see Matt. 26:47-50; Mark 14:43-46; Luke 22:47-48; and John 13:21-30.

${ }^{40}$ See Pitre, Jesus and the Last Supper, 406-411, on Christ body as bread; and 228-230, as the bread of life.
} 


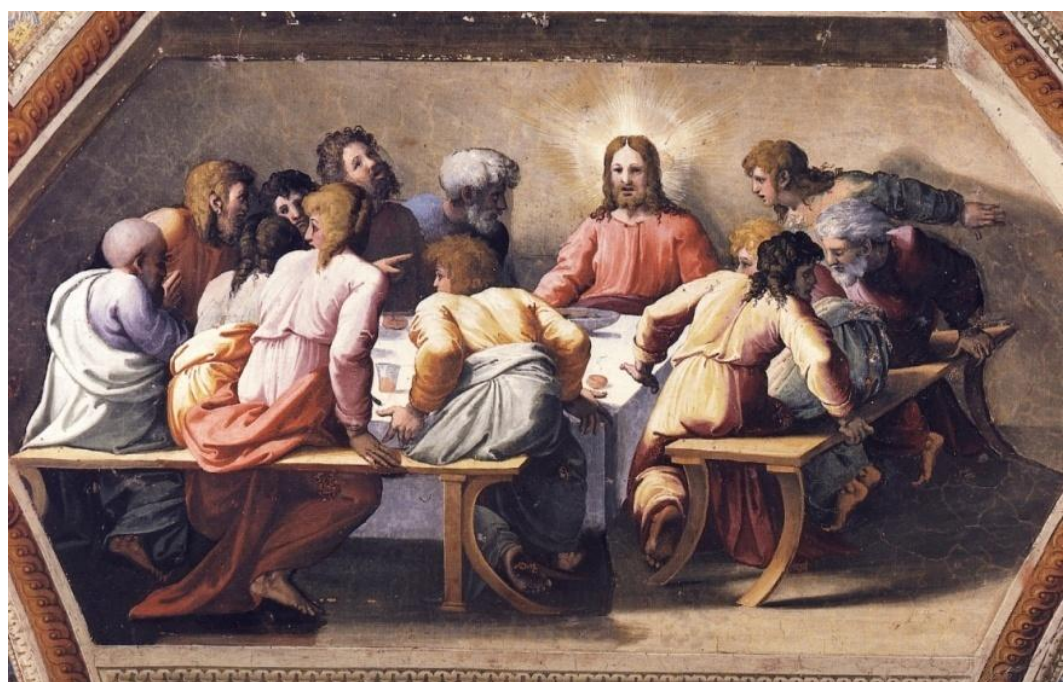

Figure 12. Raphael, Last Supper, 1515, Loggia Vaticana, Palazzi Pontifici, Vatican. Photo credit: www.abc-people.com.

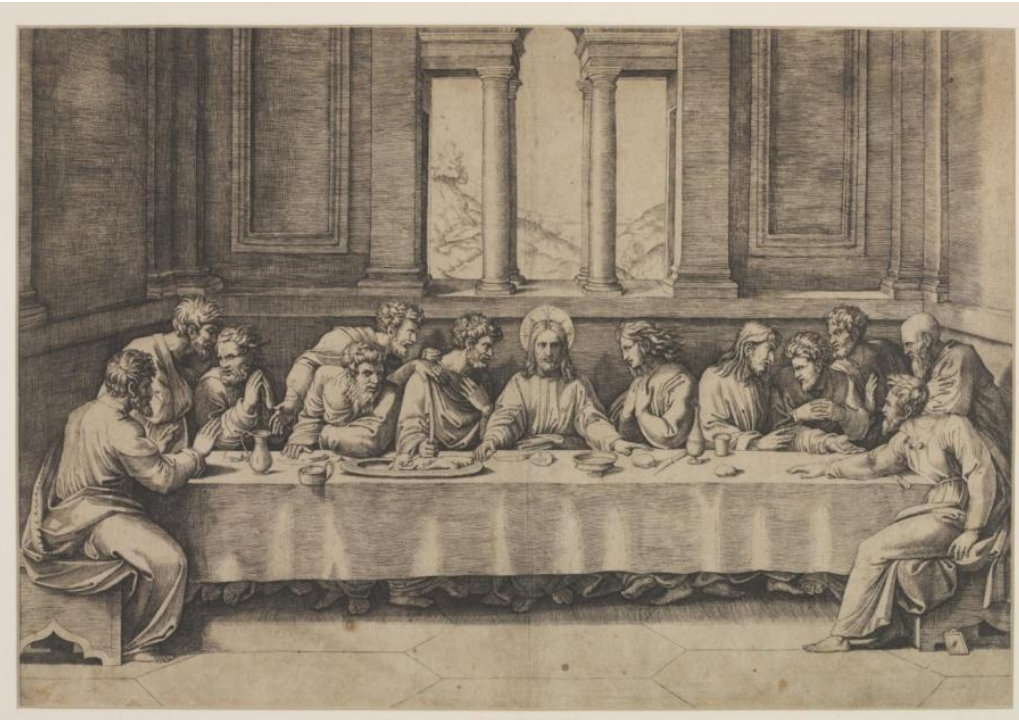

Figure 13. Marcantonio Raimondi after Raphael's Last Supper, 1515-16 engraving. Photo credit: Victoria and Albert Museum, London, Bequeathed by Rev. Alexander Dyce, DYCE.1007. 


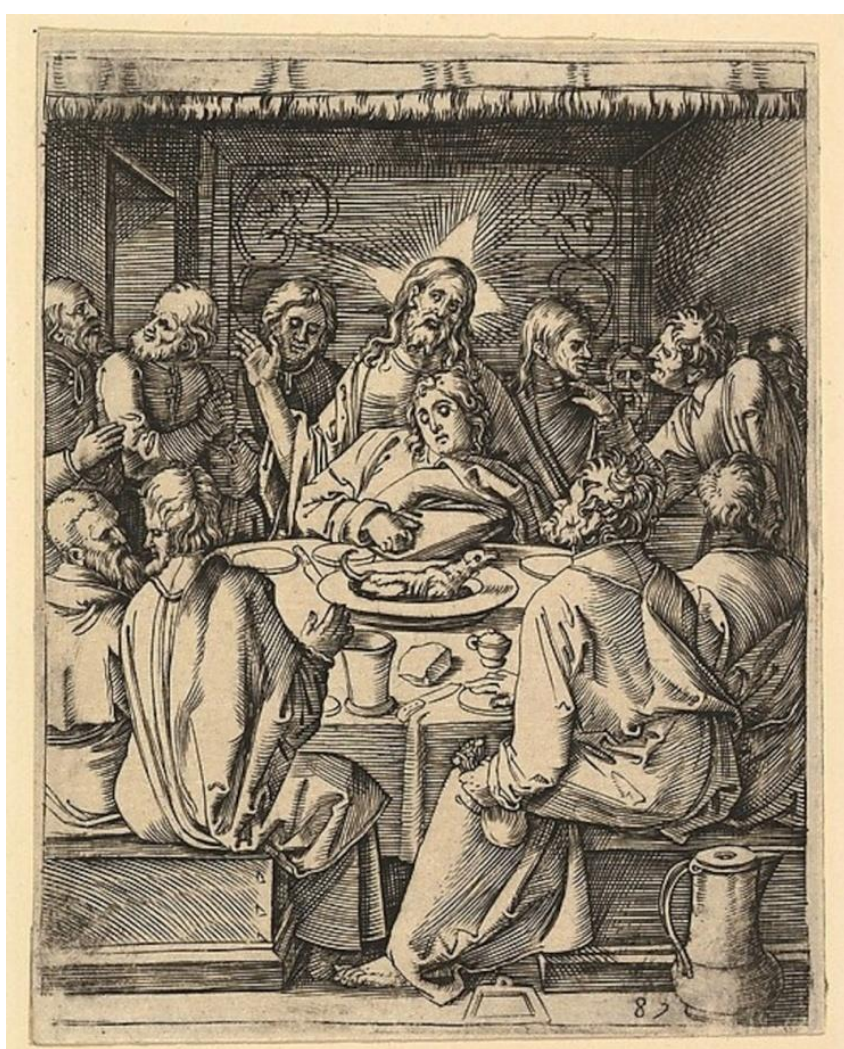

Figure 14. Marcantonio Raimondi after Albrecht Dürer's Last Supper (Passion of Christ), 1512, engraving. Photo credit: Metropolitan Museum of Art, NY. Gift of Henry Walters, 1917. Accession Number 17.37.243.

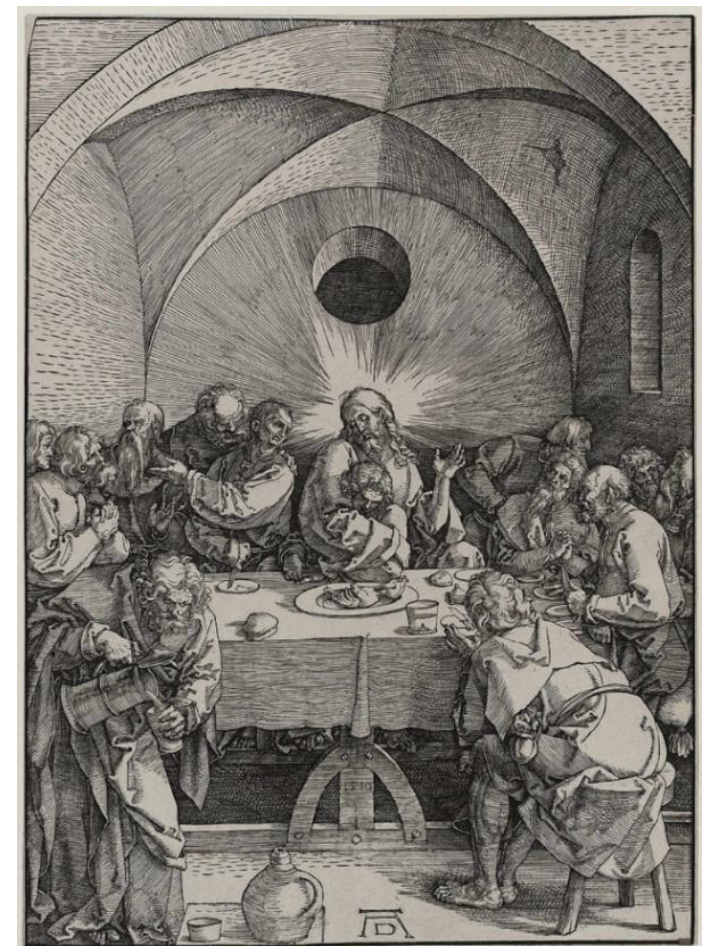

Figure 15. Albrecht Dürer, Last Supper, 1510, Albertina Museum, Vienna, Austria. Photo credit: Public domain. Wikimedia Foundation. 


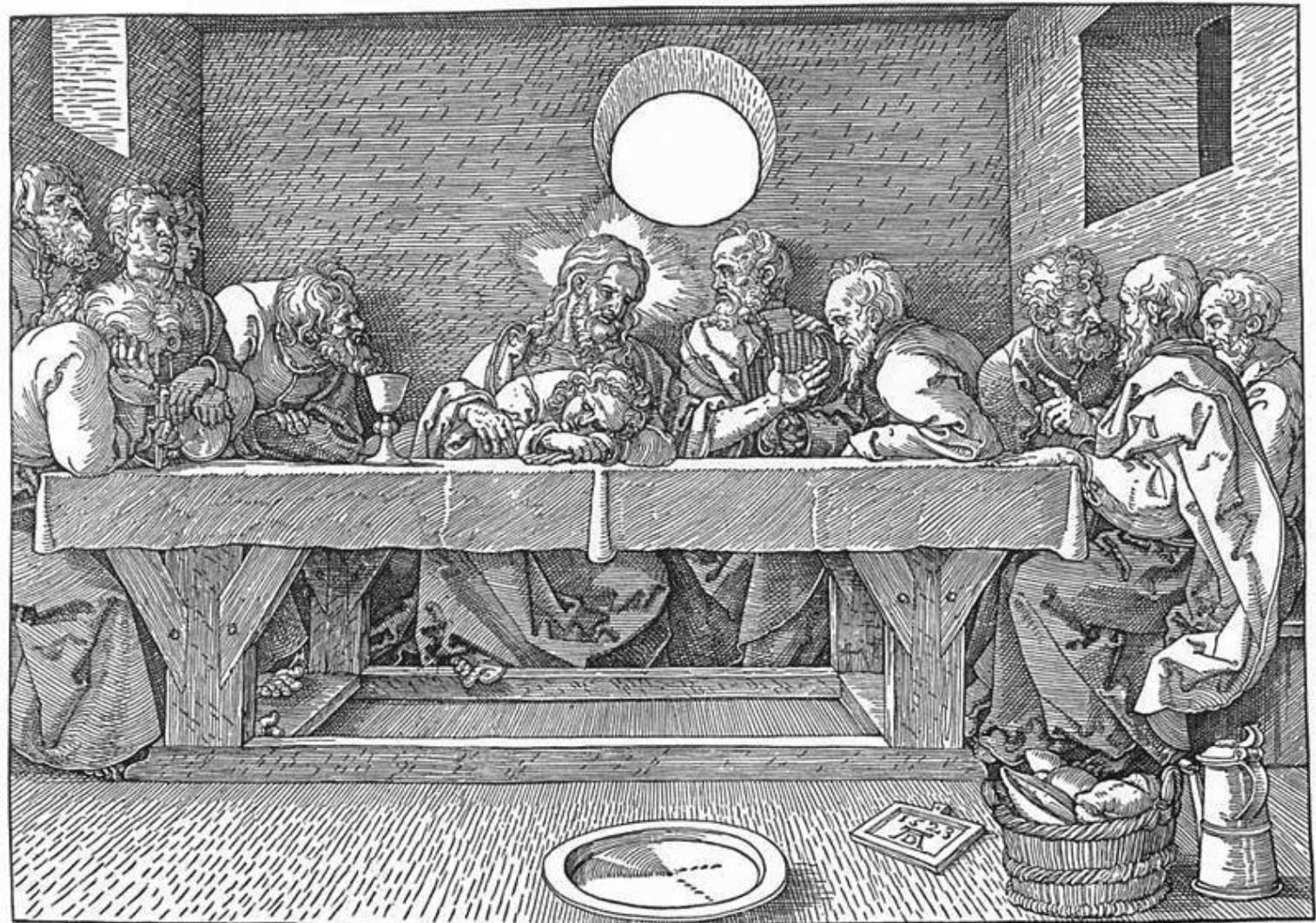

Figure 16. Albrecht Dürer, Last Supper, 1523, Albertina Museum, Vienna, Austria. Photo credit: Public domain. Wikipedia.org.

In contrast to del Sarto, the Florentines Cosimo Rosselli and Biagio d'Antonio Tucci completed a Last Supper in 1481-82 for Pope Sixtus IV (Francesco della Rovere, 1414-84) in the Sistine Chapel at the Vatican. ${ }^{41}$ Their painting focuses solely on the offering of the wine during the holy meal—Christ's covenant of wine and blood (Fig. 17); ${ }^{42}$ a large chalice is the only visible element on the table. Its placement between Christ and Judas, who sits across from Christ and separated from the other apostles, is indicative of the cause of the Passion. Judas's betrayal will result in Christ's Crucifixion. The chalice is not only a symbol of His blood shed during His trial and tortures but moreover is the cup that Christ used when drinking wine and offering blessings to His apostles: "He took a cup, and gave thanks, and gave to them, saying, 'Drink ye all of it; for this is my blood of the covenant, which is poured out for many unto remission of sins"' (Matt. 26:22-24).

\footnotetext{
${ }^{41}$ See Roma Goffen, "Friar Sixtus IV and the Sistine Chapel," Renaissance Quarterly 39, no. 2 (Summer, 1986): 218-262, http://www.jstor.org/stable/2862115.

42 See Pitre, Jesus and the Last Supper, 90-147, on the meaning of the covenant of blood and wine.
} 


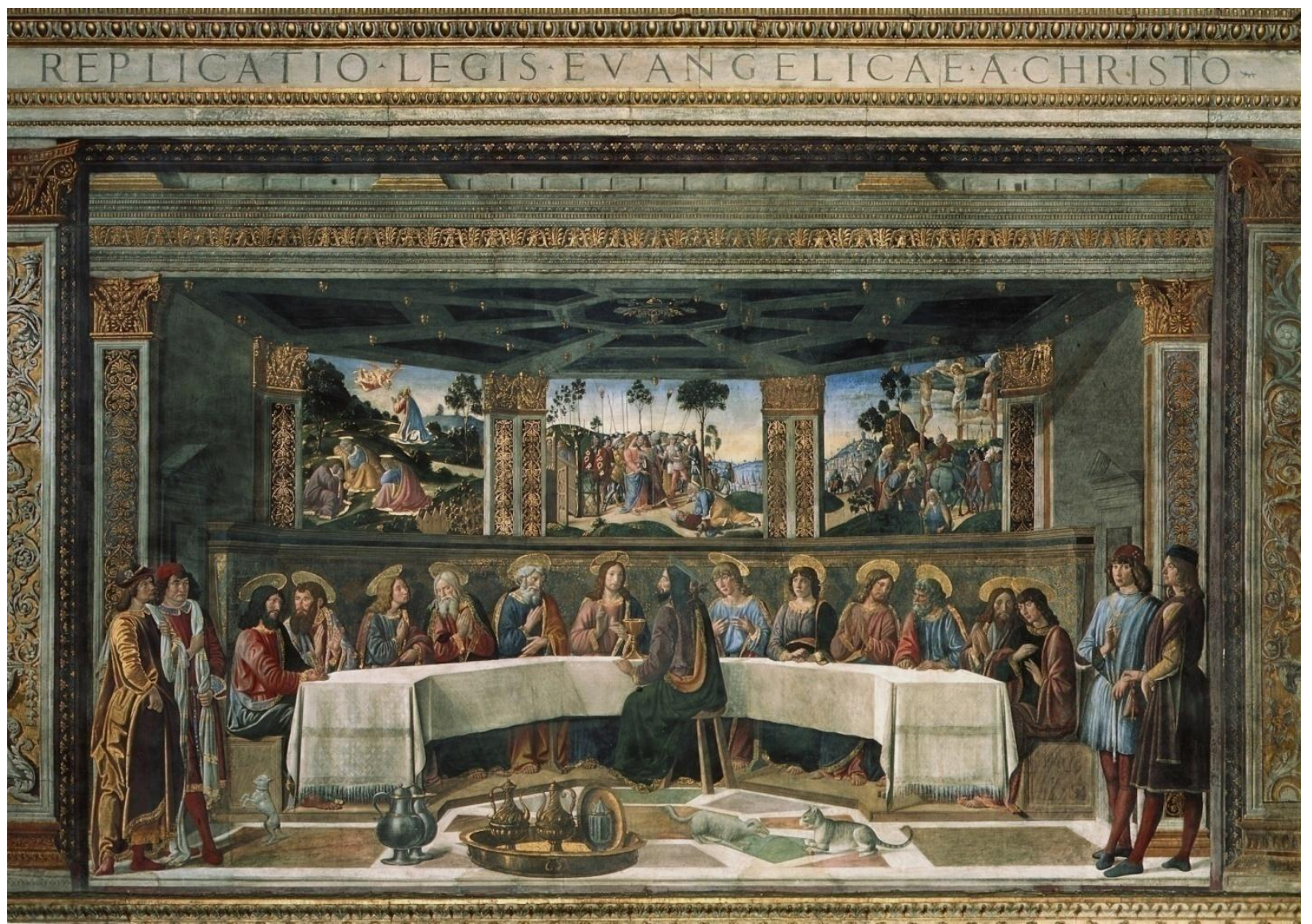

Figure 17. Cosimo Rosselli and Biagio d'Antonio Tucci, Last Supper, 1481-82. Sistine Chapel, Vatican. Photo credit:

Public domain. Web Gallery of Art.

Rosselli's scene is part of the passion cycle. In the background are three narrative scenes: The Agony in the Garden, the Kiss of Judas, and the Crucifixion. In the foreground of the Last Supper, there is a frieze with the inscription Replicatio Legis Evangelicae a Christo [Replication of Christ's Evangelic Law]. The composition of the scene is designed as an apse of a Christian basilica. On the exterior side of the semi-circular shaped table are seated apostles crowned with haloes; their reaction to Christ's betrayal announcement is depicted in a stage manner, with limited movement of their hands and facial expressions. In the interior side of the table, Judas's impassiveness to Christ's words contrasts with the fight of the cat and dog behind him. The conflict between the animals symbolizes Judas's dark and negative nature, which is further shown by his black halo and the devilish creature crawling behind his head. The overall decorative scene detracts from the solemnity of the religious event. Framing the religious scenes are two pairs of dandy spectators, whose stiff stance echoes the vertical support of the decorative piers for the architectural structure of the room; the spectators are clueless about this miraculous event.

In his Vite, Vasari criticized Rosselli, describing him as one of the less gifted among the painters at the Sistine Chapel: "However, his sheer adoption of brilliant colors granted him the appreciation of the pope, who 
apparently, was not considered an art expert." ${ }^{43}$ In contrast, Vasari highly praised del Sarto for the elegant movements of his figures; the vivid colors of purple, orange, salmon, turquoise, and green with iridescent effects as seen in the apostles' garments; and his mastery of design shown in the perspectival composition of the dining hall and the opened three partite alcove. ${ }^{44}$

With these memorable Florentine examples, ${ }^{45}$ Vasari was inspired to compose his own Last Suppers. Vasari's refectories too provide an interesting insight, in general, into the sixteenth-century taste for decorations of dining halls, or cenacoli, and, in particular, into the patronage of monastic orders such as the Benedictines with Le Murate commission in Florence; the Camaldolesi order in Casentino (Arezzo); the Augustinian order in Naples; and the Monteolivetan order with the commissions of the refectories in Bologna and Naples.

\section{Giorgio Vasari's Last Suppers}

There are two sections in this iconographical analysis of Vasari's Last Suppers. The first section considers, albeit briefly, the Last Suppers completed during Vasari's artistic period of 1537 and 1546. The second section focuses only on Le Murate Last Supper of 1546-47.

\section{Early Last Suppers}

In the early Last Suppers, Vasari stylistically followed the maniera treatment of figures, interior space, and overall compositional decoration and also adhered to the iconographical Florentine tradition of representing the theme of the Last Supper, including: a small drawing of the Last Supper for Ottaviano de' Medici of 1537 (now at the Musée du Louvre in Paris, Fig. 18); the Last Supper for the Camaldolese monastery of 1539 (Fig. 19); the refectory for San Michele in Bosco in Bologna of 1539-41; the Suppers for the refectory (now sacristy) of Sant' Anna di Monteoliveto (Sant' Anna del Lombardi) in Naples (1544-45); one of the meal panels for the sacristy of San Giovanni a Carbonara in Naples of 1545 (now in the Musée des Beaux-Arts in Troyes, Fig. 20 ); ${ }^{46}$ and the Supper panels from the Old Testament, including the Last Supper of 1545, for Raffaele Acciaioli (now at the Walters Art Museum in Baltimore, Fig. 21). ${ }^{47}$

\footnotetext{
${ }^{43}$ See Gaston Du C. de Vere, ed. and trans. Giorgio Vasari's Lives of the Most Eminent Painters, Sculptors, and Architects (New York: Harry N. Abrams, Inc., 1979), p. 621; and Arthur R. Blumenthal et al. Cosimo Rosselli: Painter of the Sistine Chapel (Winter Park: Cornell Fine Arts Museum, 2001), Introduction.

${ }^{44}$ See Antonio Natali and Alessandro Cecchi, Andrea del Sarto (Florence: Cantini, 1989), 106; and Sydney Joseph Freedberg, Andrea Del Sarto, 2 vols. (Cambridge, MA: Belknap Press of Harvard University Press, 1963), passim.

45 In the Last Suppers for Santa Maria Novella (ex-refectory) and Santa Maria del Carmine (ex-refectory) of 1584 and 1597 , Alessandro Allori continued to assimilate del Sarto's stylistic and iconographical renditions. Although included in the Cinquecento style, Allori's cenacoli will not be considered because they were painted after the death of Vasari, hence beyond the scope of this study. See E. Pilliod, Pontormo, Bronzino, Allori. A Genealogy of Florentine Art (New Haven and London: Yale University Press, 2001). Also in late 1560s, the Dominican nun Plautilla Nelli (1524-1588) had completed a Last Supper for the monastery of Santa Caterina da Siena (ex-refectory) in Piazza San Marco in Florence. The only signed work by this female painter. This large religious painting of almost 22 feet long in oil-on-canvas is presently being restored and not visible to the public. When the restoration is completed a comparative study between Vasari's Le Murate Last Supper and Nelli's Last Supper-two thanksgiving celebrations for monasteries of nuns-would be insightful. See Bettarini-Barocchi, Vite, IV:404, on Vasari's comments about sister Nelli; and Ann Roberts "Plautilla Nelli's Last Supper and the Tradition of Dominican Refectory Decorations," in Jonathan Nelson, ed., Suor Plautilla Nelli (1523-1588): The First Woman Painter of Florence (Florence: Edizione Cadmo,1999), 72-87.

${ }_{46}$ Vasari later completed a mostly identical Last Supper as a predella panel for the high altar in Santa Croce at Bosco Marengo (Boscomarengo) in 1568. See Beppe Merlano, Vasari a Bosco Marengo: Studi per il restauro delle tavole Vasariane in Santa Croce (Savignone: SAGEP, 2010), 9-11.

${ }^{47}$ Two years later, after the completion of his Le Murate Last Supper, Vasari painted a very large Last Supper for the refectory of the Badia of SS. Flora and Lucilla in Arezzo (1548); a drawing at the Gabinetto dei Disegni e delle Stampe degli Uffizi (no. 392) of a predella for an altar. See Cheney, "Vasari and Naples," 48-126; and Härb, The Drawings of Giorgio Vasari, 284-295.
} 


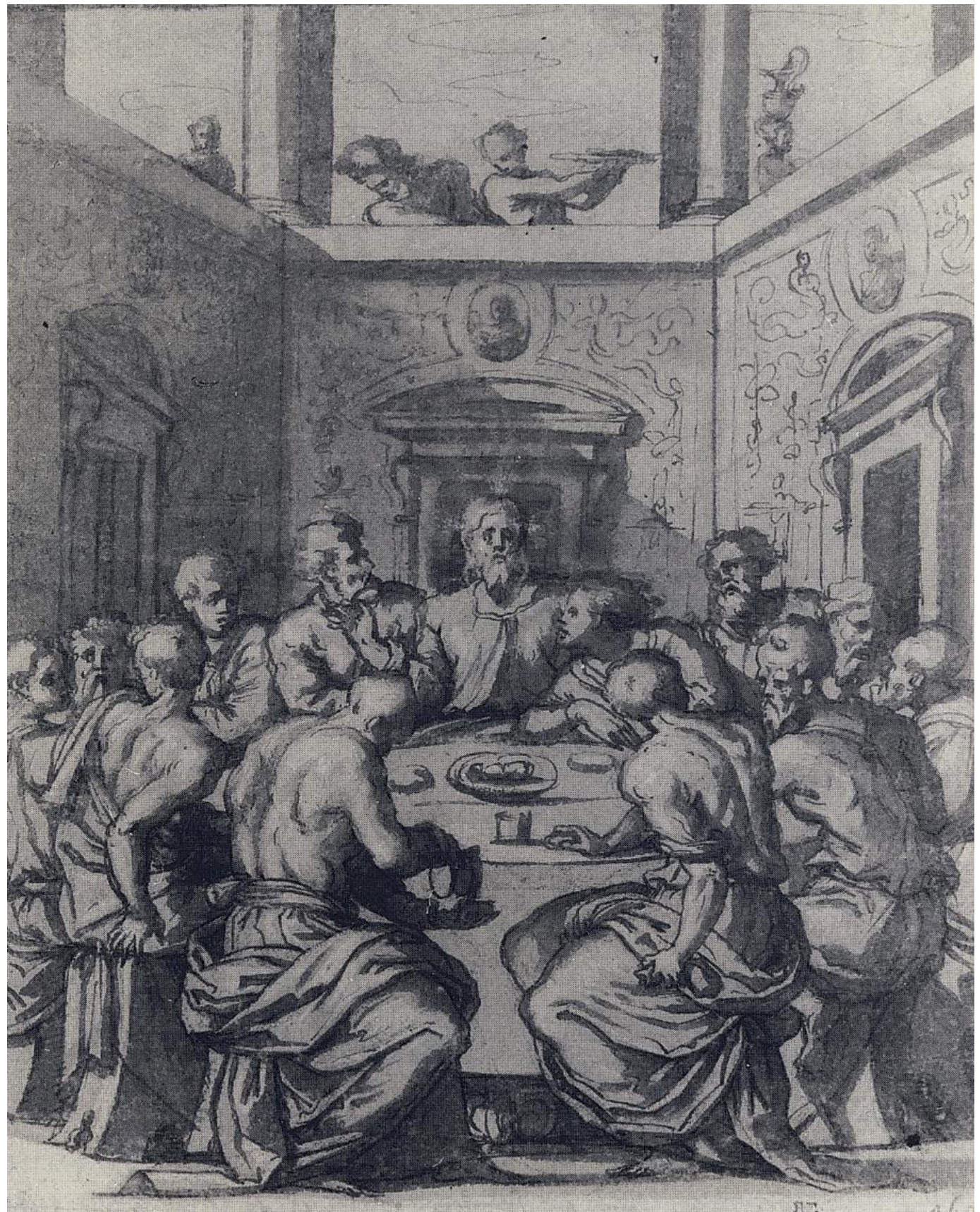

Figure 18. Giorgio Vasari, Last Supper, 1537, Inv. 4287. Musée du Louvre, Paris. Photo credit: Musée du Louvre, Paris. 


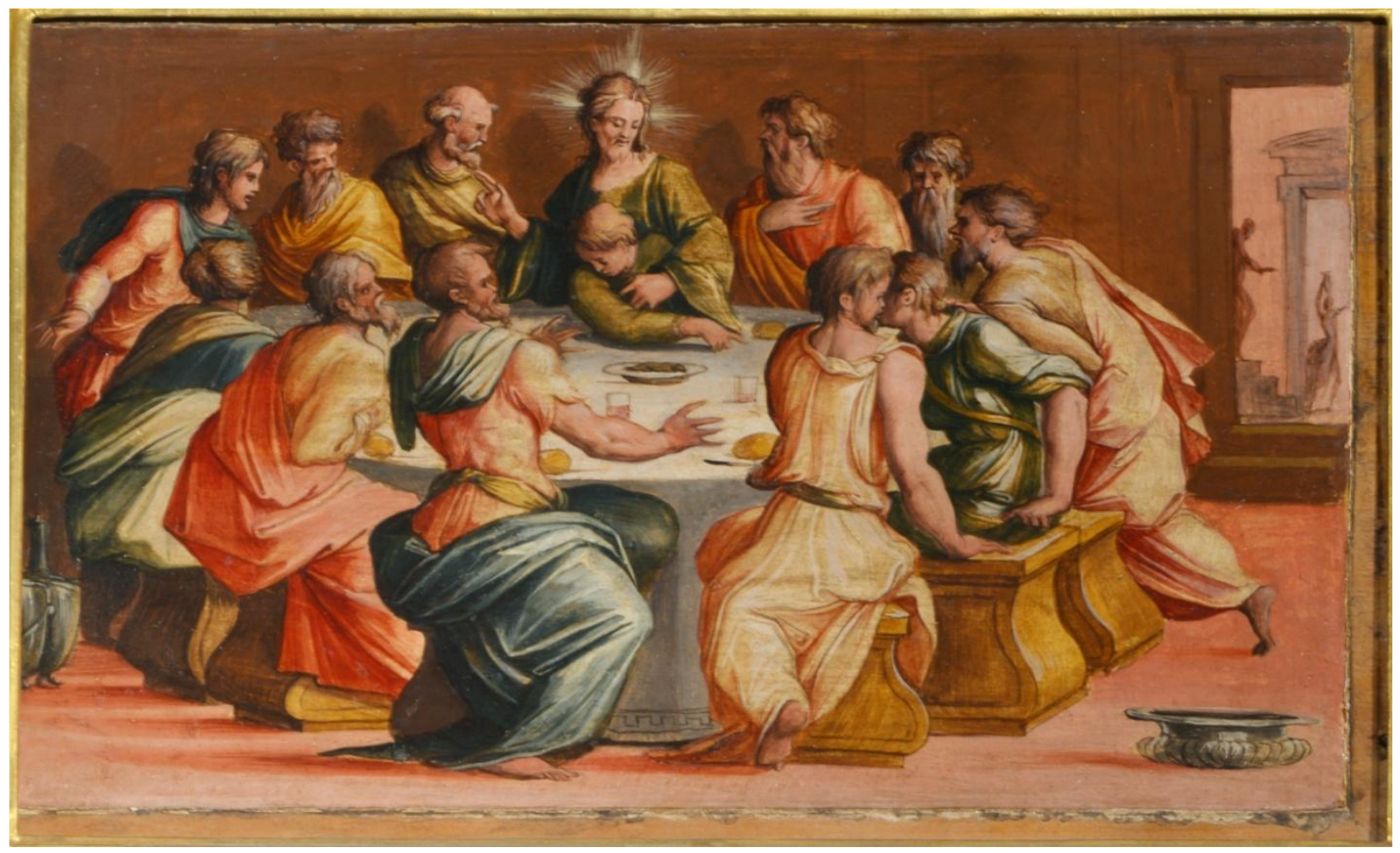

Figure 19. Giorgio Vasari, Las Supper, 1539. Camaldoli Monastery (Arezzo). Photo credit: Foto Tavanti, Arezzo.

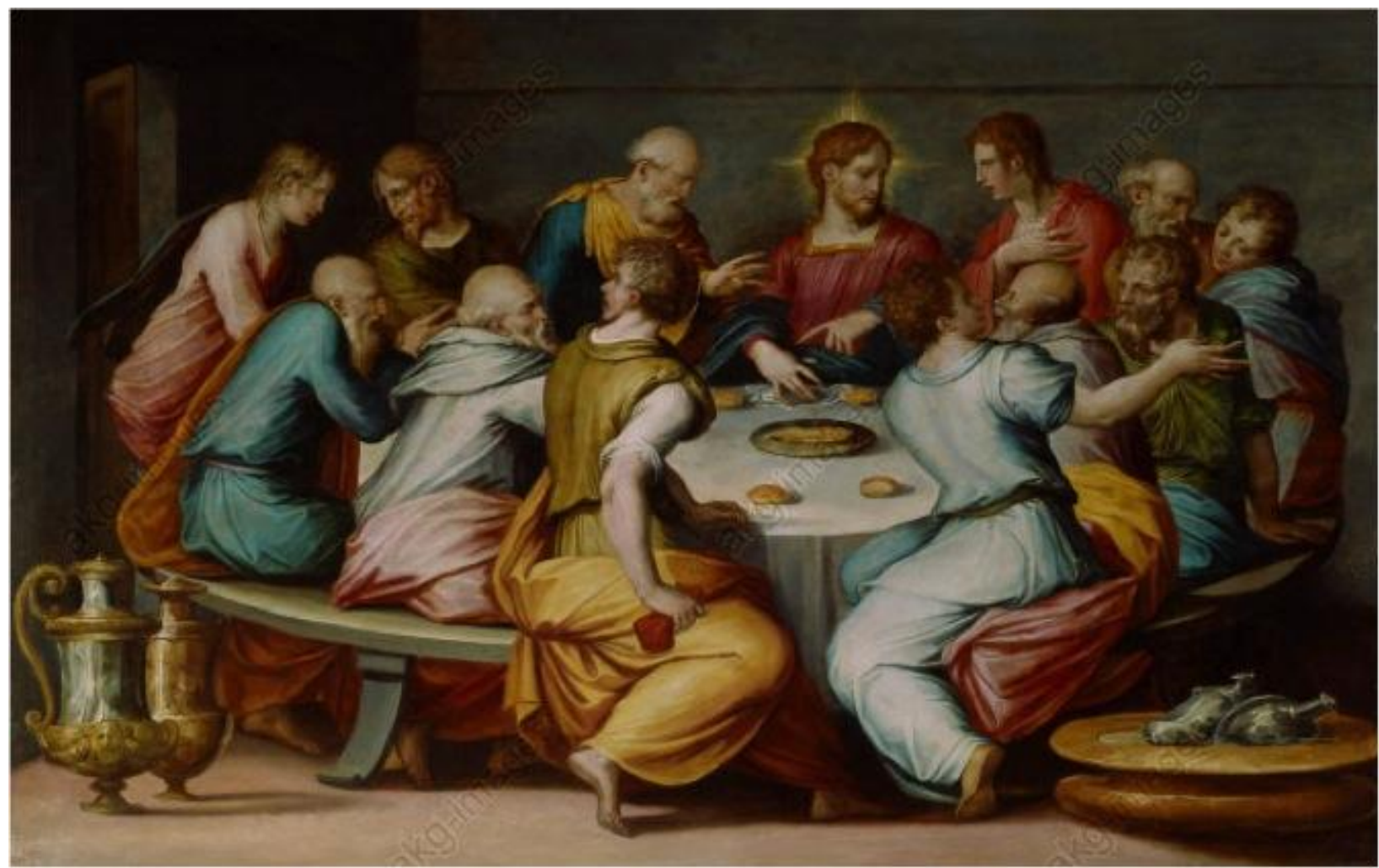

Figure 20. Giorgio Vasari, Last Supper, 1545, Musée des Beaux-Arts, Troyes. Photo credit: Liana De Girolami Cheney. 
Vasari's drawing of the Last Supper for Ottaviano de' Medici (1484-1546), a distinguished member of the Medici family and Florentine political leader (Fig. 18), is documented in a ricordo dated 1 January 1537, where Vasari cited the commission of a small painting of a Last Supper for Ottaviano de' Medici.

Ricordo come a di primo di Gennaio 1537 il magnifico messer Ottavjano de Medici ebbe da me un quadro, dentrovj la storia di X.o quando egli cena con gli apostolj, d'altezza di braccja uno e mezzo et uno e terzo largho, per valuto di docidi [scudi].

[I remember how on the first of January 1537, the honorable Ottaviano de' Medici received from me a painting, inside it [depicting] story of Christ having a meal with his apostles. [The size of $1 \frac{1 / 2}{2}$ braccia in height and $11 / 3$ braccia in length for twelve [scudi].] $]^{48}$

According to Florian Härb, Vasari's painting, presently lost, was part of the Medici's art collection. Catherine Monbeig Goguel identified a drawing for this commission, presently at the Cabinet des Dessins at the Louvre (inv. 4287) (Fig. 18). ${ }^{49}$ The disegno executed in pen and brown ink, with brown wash, heightened in white chalk, over black chalk, is one of Vasari's earliest Last Supper studies. The banquet scene takes place in a private room. The compressed space is divided in two parts. The upper part contains a partial colonnade opening where the servants are bringing the prepared food, while the lower part, which occupies three-quarters of the drawing, is designed with three walls decorated with grotteschi. In the center of each wall there is a Mannerist aedicule, above which hangs a large ovato (oval) portrait. In this disegno, Vasari demonstrated his assimilation of classical architecture (gained during his early Roman sojourn in 1529 and studies of the Pantheon's aedicule of 118-25) and also echoes Michelangelo's aedicule from the ricetto (anteroom) of 1534 in the Laurentian Library in Florence. ${ }^{50}$ No doubt Michelangelo's Medicean commission was on Vasari's mind when he designed the Last Supper for Ottaviano de' Medici. In the drawing, Vasari designed a round table at which the last meal is taking place. Christ is crowned with a radiating cross; John cuddles up to Him during the announcement of the betrayal; Judas, identifiable because he holds a pouch, turns his head away from Christ to speak with another apostle. All the apostles, seated on separate stools, talk excitedly among themselves. Few edible items are visible on the table: some bread, a glass of wine, and a dish with lamb. Although Vasari retained an overall classical composition in the architecture and elegant treatment of the figures, some of whom are semi-clothed, some of the compositional design (round table) and action of the apostles (one in particular pouring himself a glass of wine) suggest the influence of northern Renaissance art, viz., Albrecht Dürer's prints as seen in the engraving of the Last Supper of 1510 from the Passion Cycle at the Albertina Museum in Vienna (compare Figs. 15 and 18). ${ }^{51}$

\footnotetext{
${ }^{48}$ See Karl Frey, Der literarische Nachlass Giorgio Vasaris, 2 vols. (Munich: George Müller, 1923), 2:855, no. 87; and Gaetano Milanesi, Giorgio Vasari, Le vite de più eccellenti pittori, scultori e architettori, 9 vols. (Florence: Sansoni, 1970-1974) (hereafter cited as Milanesi-Vite), 7:657.

49 See Härb, The Drawings of Giorgio Vasari, 170.

50 See Wolfgang Lotz and Deborah Howard, Architecture in Italy-1500-1600 (New Haven: Yale University Press, 1974, rev. 1995), 93-94.

${ }^{51}$ In this print, Dürer's crude treatment of the figures and employment of a harsh line indicate the apostles' poverty and the treatment of sharp lines in the engraving technique. See also Sharon Gregory, Vasari and the Renaissance Print (Burlington, VT: Ashgate, 2012), 164; and Getscher, An Annotated and Illustrated Version of Giorgio Vasari's History of Italian and Northern Prints, 151.
} 
In 1539, for the monastery of the Camaldoli in Casentino, ${ }^{52}$ Vasari completed several paintings to be placed in the recently constructed large rood screen in the main church: Our Lady with SS John the Baptist and Jerome; Nativity of Jesus; The Deposition of Christ; and 10 small paintings of which only eight have survived. ${ }^{53}$ Some of the surviving panels represent Bible stories of meals and sacrifices, including the Old Testament stories of The Sacrifice of Abel, The Sacrifice of Isaac, The Fall of Manna, The Meeting of Abraham and Melchizedek, and The Miracle of the Broken Chalice as well as the New Testament story of the Last Supper. Vasari will repeat these themes in later commissions of predella panels and altarpieces, at times limiting or expanding the narrative of these biblical stories.

Explanations for the configuration of last suppers in the New Testament can be found in Old Testament representations of meals as such as the Passover Seder (Exod. 12:12-14), a festival of the Lord, along with the Sacrifice of Abel, the Fall of Manna, the Sacrifice of Isaac, Abraham and the Three Angels, and the Meeting of Abraham and Melchizedek. ${ }^{54}$ These Old Testament themes are the ante legem or prefiguration of such last-supper themes in the New Testament as Christ in the House of Martha and Mary, Christ in the House of Simon, the Wedding at Cana, and Christ's Last Supper. Iconographical parallels exist between the miracle of the manna in the desert and the bread of life or the bread of heaven (John 6:31-33, 1 Cor. 10:1-4). This connection relates to the early Christian practice of sharing a Messianic meal of bread and wine - called eukharistia, from the Greek word meaning thanksgiving, because the prayer pronounced before eating expressed gratitude to God for the gifts about to be received. Thus the Old Testament's food gathering and blessings prefigure the New Testament's Eucharistic meal.

Vasari's Camaldoli Last Supper takes place in a small room and provides a glimpse into an adjacent room, where the servants are carrying food (Fig. 19). The scene has a simple décor, with emphasis on Italian Renaissance architecture such as the doorway frames and seating furnishings such as the stools. The holy supper takes place around a circular table at which the apostles surround Christ. While He is blessing the meal, a radiant white cross crowns Him and reveals His divinity. Peter is seated on the left side of Christ, while John collapses in front of Christ, and Philip points to himself wondering if he is being considered the betrayer. In the foreground, an unusual episode is unfolding: one of the apostles turns toward another and sees how his adjacent friend is clinging to a pouch. Vasari has identified Judas for the viewer. Judas's face is partially covered by his seated partner who unfortunately has discovered his secret and Christ's betrayer. Some vessels and a large

\footnotetext{
52 The Camaldolesi Order is a hermetical and cenobitical order of the eleventh century that branched out from the Benedictine order. Its founder, Saint Romuald, found a new hermitage in the Diocese of Arezzo, and later the order expanded to Camaldoli. Vasari, a native of Arezzo, was closely associated with the order because his classical tutor and canon Polio Giovanni Lappoli, known as Pollastra (1465-1540), was connected to this order, and Vasari spent time with him in Camaldoli. Vasari benefited from the relationship by receiving a major commission at Camaldoli, which included painting images for the rood screen of the main church, on the biblical theme of the supper. See a letter that Vasari wrote in 1537 from Camaldoli to Pollastra in Arezzo in Frey, Der literarische Nachlass Giorgio Vasaris, I, XXXIII, 89-91. See Milanesi-Vite, 5:164; 6:10-13; 7:6-7, 660; and 8:273-274; J. Kliemann, "Vasari, Pollastra e l'allegoria della 'Concezione," in Corti, Giorgio Vasari. Principi, letterati e artisti nelle carte di Giorgio Vasari, 103-105. In addition, the canon's nephew, Giovanni Antonio Lappoli (1492-1552), was also an Aretine painter who tutored Vasari. See Milanesi-Vite, 3:219-221; and Freedberg, Painting in Italy, 1500-1600, 464.

I want to express my gratitude to Padre Ugo of the Camaldoli Monastery for permitting Rossi Roberto Tavanti of Arezzo to photograph Giorgio Vasari's panels of the Old and New Testament in the convent, in particular the Camaldoli Last Supper here reproduced as Fig. 19.

${ }^{53}$ See Paola Barocchi, Vasari Pittore (Milan: Club del Libro, 1964), 115-116; and Manuela Alotto, "Contributi documentari su Giorgio Vasari a Camaldoli," Arte Cristiana 855 (November/December, 2009): 469-474.

${ }^{54}$ See Pitre, Jesus and the Last Supper, 448-482, for a discussion of the Messianic banquets and early Judaism as well as sharing a meal, eating and drinking with Abraham, Isaac, and Jacob.
} 
silver bowl are displayed for perspectival construction. Compositionally, Vasari incorporated artistic elements from Raphael's Vatican Last Supper, such as the round table; the twisting and turning of the figures in the foreground; and the centrality of Christ focusing on His divinity through the aureole radiant effect (compare Figs. 12 and 19). Vasari also assimilated the vivid colorito of his teachers Giovanni Antonio Lappoli and Rosso Fiorentino. $^{55}$

In this religious meal, Vasari is probably visualizing a familiar Camaldolesi supper, replacing the monks with the apostles, who are seated on separate stools and are reacting to Christ's blessings of the bread. Wine glasses, knives, and bread are placed on the table in front of each apostle, and a large dish in the center of the table contains parts of a lamb, "symbol of Christ in his sacrificial role." 56

While in Naples in 1545, Vasari painted small devotional panels on the theme of the Last Supper. These panels were painted for the Augustinian order to enhance the spirituality in the sacristy in San Giovanni a Carbonara (coal-carriers) in Naples. Today this Last Supper is found at the Musée de Beaux-Arts et d'Archéologie in Troyes (Fig. 20). ${ }^{57}$ Vasari repeated most of the composition from the Camaldolesi painting in this Troyes Last Supper (compare Figs. 19 and 20). He only changed the seating arrangement, switching the door opening from right to left and using a long sitting bench instead of individual stools. On the left of the composition he added large wine vessels; on the right side he placed two wine bottles in a large bowl, although no wine glasses are on the table. The significant changes in the Troyes Last Supper are: the substitution of John next to Christ pointing to his chest, instead of the apostle Philip; and the placement of Judas in full view holding his moneybag. In the Troyes Last Supper, Vasari's colorito is heightened, and his disegno is rendered carefully in his treatment of the figures.

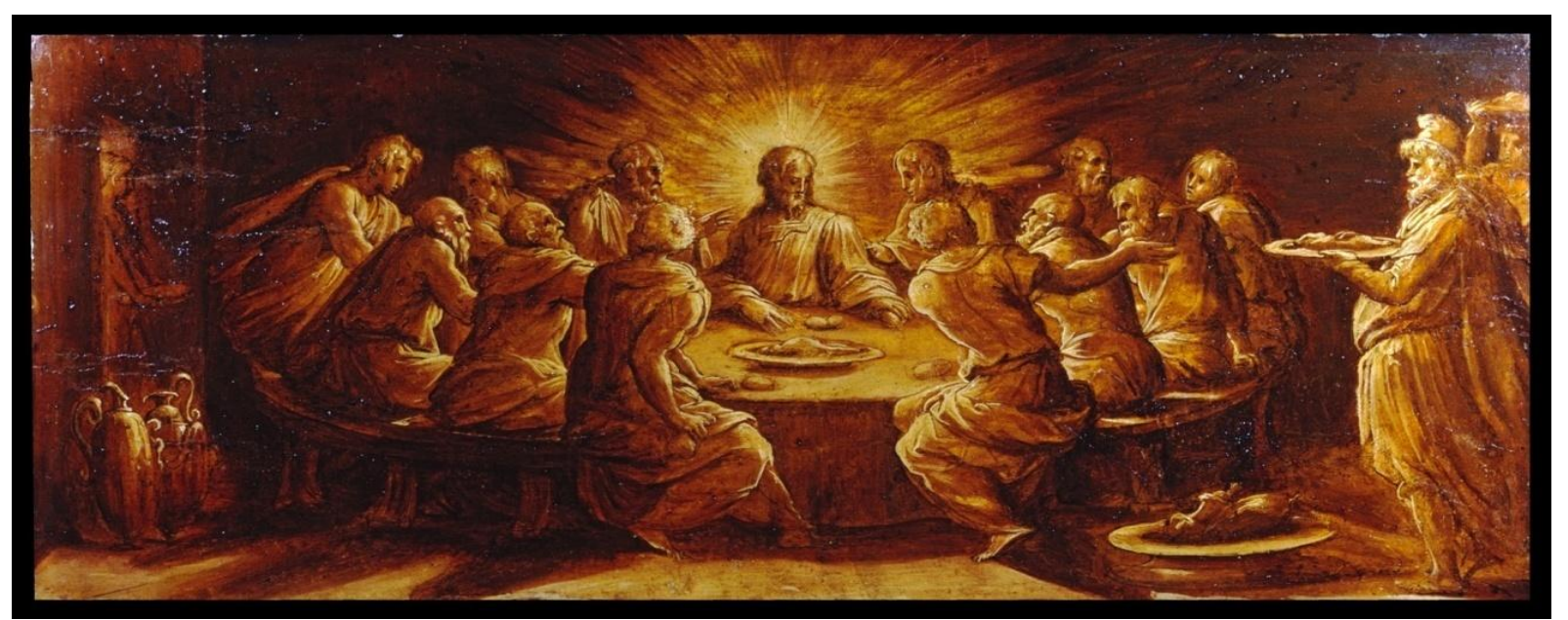

Figure 21. Giorgio Vasari, Last Supper, 1545 for Raffaele Acciaioli. Now Walters Art Gallery, Baltimore, MD. Photo credit: Liana De Girolami Cheney.

\footnotetext{
55 See Barocchi, Vasari Pittore, 18, 31, and 34; and Eugene A. Carroll, "Lappoli, Alfani, Vasari, and Rosso Fiorentino," The Art Bulletin 49 (1967): 297-304; Donatella Fratini, "Un profilo di Arezzo nel '500: Guillaume de Marcillat, Giovann’Antonio Lappoli e Niccolò Soggi nelle 'Vite' del Vasari," in Arezzo e Vasari, ed. Antonino Caleca (Foligno: Cartei \& Bianchi, 2007), 67-83; and Roberto Paolo Ciardi and Alberto Mugnaini, Rosso Fiorentino (Florence: Cantini, 1991), passim.

${ }^{56}$ See Pitre, Jesus and the Last Supper, 406-409, lamb's flesh; 268-470, lamb as sacrifice; and Hall, Dictionary of Subjects and Symbols in Art, 185.

57 See Corti, Vasari, 64, for an explanation of this panel as a political cultural exchange from Naples to France in 1788, obtained by the Troyes Museum in 1876. See Ida Maietta, "I dipinti di Giorgio Vasari per la sagrestia di San Giovanni a Carbonara," in Vasari a Napoli: I Dipinti della sagrestia di San Giovanni a Carbonara: il restauro, gli studi, le indagini, ed. Ida Maietta (Naples: Paparo, 2011), 31-39.
} 
A similar subject matter was commissioned by the Florentine-born Raffaele Acciaioli, a banker and merchant for wheat transport from Florence to Naples who resided in Naples in $1545{ }^{58}$ This small devotional painting is in brown monochrome color, demonstrating Vasari's technique in "pen drawing with retouches of layers of paint with brush and fingers. ${ }^{59}$ Today the painting is at the Walters Art Gallery in Baltimore, MD (Fig. 21). In addition to this Last Supper, Vasari also completed for the Acciaioli several small paintings with a meal subject associated with Old Testament stories similar to those executed for the Camaldoli and Augustinian orders, such as The Fall of Manna, where God provided bread for the starving Israelites in the desert (Exod. 16:15-16), ${ }^{60}$ and The Meeting of Abraham and Melchizedek, where Abraham and his soldiers received a meal of bread and wine from the high priest Melchizedek after their battle at Sodom to save Abraham's nephew Lot and his family (Gen. 14:24; Heb. 7-10). ${ }^{61}$ As mentioned above, these Old Testament meal scenes prefigure the New Testament Last Supper and Eucharist.

For the Acciaioli Last Supper, Vasari composed a complex scene formed in three parts as an early Christian triptych: (1) On the left, through an open door, a servant can be seen coming from the kitchen and carrying a plate of food; in front of the door, large vessels contain wine. (2) On the right are two servants: a young lad carrying the food plate on his head and an older man who holds a plate with piece of lamb. The latter figure might be the patron or the main cook because of his different attire. He is the only person wearing a Phrygian cap. ${ }^{62}$ In front of him on a small table rests a large plate of lamb. (3) And, in the center of the painting, around an oval table decorated with an all'antica sitting bench and classical scrolls for leg support, Vasari placed the apostles around Christ.

Ingeniously, Vasari divided the oval table setting into three parts: Christ is seated in the center, and on each side of Him are seated six apostles. In order to emphasize this holy moment, Vasari designed two special areas: one is the background, crowning Christ with a radiating sun-disk that expands its luminous rays with a rippling effect, hence illuminating the whole semi-dark room. The other is in the foreground, leaving an open and empty space at the table in the center, directly facing Christ. Through this opening we see that the folds of the tablecloth drape in the shape of a cross. In part this open place-setting is an invitation for the viewer to participate in the Eucharistic event. (Vasari will elaborate on this artistic conceit in his Le Murate Last Supper.)

On the table, a large plate with a leg of lamb is placed axially across from the viewer as a special place-setting in front of Christ. The moment Vasari portrays in his thanksgiving is the blessing of the bread; the only other staple in view at the table is a bowl with pieces of lamb. Christ is blessing pieces of bread and distributing them to His apostles, while announcing His betrayal. Christ's temperate and calm action is further

\footnotetext{
58 See Härb, The Drawings of Giorgio Vasari, 285, n. 357, citing Frey, Der literarische Nachlass Giorgio Vasaris, 2:864, n. 159. The Florentine-born Raffaele Acciaioli resided in 1545 in Naples during the same time that Vasari was completing the ceiling decoration for the Refectory of Monteoliveto (now sacristy).

59 See Federico Zeri, Italian Paintings in the Walters Art Gallery with Notes by Elisabeth G. Packard and Ursula E. McCracken (Baltimore: Walters Art Gallery, 1976), Catalogue Entries 216a-d, 333-335.

${ }^{60}$ See Bible, New International Version (NIV, public domain), Exod. 16:15-16: "Moses said, 'It is the bread the LoRD has given you to eat.' This is what the Lord has commanded, 'Everyone is to gather as much as they need. Take an omen [3 pounds] for each person you have in your tent.",

${ }^{61}$ Gen. 14:18-20: "And Melchizedek king of Salem brought out bread and wine; he was priest of God Most High. And he [Melchizedek] blessed him [Abraham] and said, 'Blessed be Abram by God Most High, maker of heaven and earth; and blessed be God Most High, who has delivered your enemies into your hand!'”

62 Perhaps Vasari was denoting an Eastern quality about the place of the meal. See Hall, Dictionary of Subjects and Symbols in Art, 145, on the Phrygian bonnet. In a later commission, The Wedding at Cana of 1564, Vasari will repeat the same figure as one of the servants for the meal. See Härb, The Drawings of Giorgio Vasari, 332, Fig. 175, for a drawing at the Albertina Museum in Vienna (Inv. 506).
} 
implied in the displayed vessels of wine, placed on the left side of the painting, which alludes to the cardinal virtue of Temperance. ${ }^{63}$ Not by accident did Vasari paint a servant carrying a plate with bread, a symbol of Christ's body, just as the wine contained in the vessels is a symbol of Christ's blood. In contrast to Christ's composure, the apostles react in various agitated manners: John, on the left side of Christ, immediately touches Him; Peter, on Christ's right side, abruptly stands up and raises his hand; another apostle awkwardly turns toward a servant to reach for a plate of lamb; while Judas tensely grabs his moneybag and turns his head away from Christ. Judas is seated diagonally opposite to Christ, but next to him there is an open space, making visible on the linen tablecloth the depiction of a cross. Vasari's design inspires the viewer to recall the reason why Judas is holding onto the pouch and withdrawing from Christ: he will be responsible for Christ's capture and crucifixion by Roman soldiers. Judas's gilt will culminate in his committing a sin of wrath, one of the seven deadly sins, a contrast to the virtue of temperance imparted by Christ during the supper, a contrast also visualized in the depiction of the paired vessels. ${ }^{64}$

Further analysis of the depiction of these examples of the Last Supper shows some interesting common changes. For example, the composition in these small devotional panels consists of a simple domestic interior primarily dominated by a circular table around which the apostles and Christ sit in close proximity. Only a few culinary objects (wine jugs and large plates) are displayed in the scene. In these depictions, Vasari intentionally conveys a strong sense of intimacy in the scene and also provides a didactic moral message to the viewer, alluding to the triumph of the virtues of temperance, hope, and love (charity) over the vices of greed, despair, and betrayal.

Also, in the refectories of San Michele in Bosco and Santa Anna dei Lombardi, Vasari challenged the conventional thematic tradition of decorating walls and ceilings of refectories with religious themes based on the Crucifixion and Last Supper. He visualized an iconography predicated on the instructions of the Monteolivetan order. ${ }^{65}$ Vasari rendered tangibly and visually the order's concept of monastic living, that is to say, the "monks seek to be like Christ an icon or an image of God's beauty, and the monastery is that quiet place where the work can be perfected - a kind of atelier of the soul." ${ }^{\prime 66}$ In 1994, I wrote at length on the iconography and iconology of the refectories of these Monteolivetan monasteries; hence I will not examine them in this essay. ${ }^{67}$

The next section of this essay focuses specifically on the commission for Le Murate Last Supper and Vasari's innovations for a successful completion for this remarkable cenacolo.

\footnotetext{
${ }^{63}$ See Hall, Dictionary of Subjects and Symbols in Art, 248.

${ }^{64}$ Prudentius described this type of moral battle between good and evil or virtues over vices in his fifth-century poem Psychomachia. See Prudentius, Psychomachia, ed. Rosemary Burton (Bryn Mawr, PA: Bryn Mawr Commentaries, 1989). For the symbolism of the vessels and pouring as the virtue of Temperance, see Tervarent, Attributs et Symboles dans L'Art Profane, p. 27. ${ }^{65}$ See Franco Strazzullo, "La fondazione di Monteoliveto in Napoli," Napoli nobilissima 3 (1963-1964), 103-111; and Don Modesto Scarpini di Asciano, I Monaci Benedettini di Monte Oliveto (Alessandria: L'Ulivo, 1952), for the history of the Monteolivetan order to the present. Fra Antonio di Guccio da Barga wrote the first book on Monteolivetan history: Chronicon Montis Oliveti (1313-1450). See https://archive.org/stream/chroniconmontis00lugagoog-chroniconmontis00lugagoog_djvu.txt; accessed 2 January 2015.

${ }^{66}$ See T. G. Verdon, Monasticism and the Arts (Syracuse, NY: Syracuse University Press, 1984), 2; G. Ferrari, Early Roman Monasteries (Rome: Pontificio Istituto di Archeologia Cristiana, 1957); and P. Helgot and M. Bullot, Ordini Religiosi, 8 vols. (Lucca: np, 1737-1739), vol. 7 on Naples.

67 See Cheney, "Vasari and Naples," 48-126.
} 


\section{Le Murate Last Supper}

In this arduous religious commission of the Last Supper for the female monastery, the Benedictine Monastery of Le Murate (The Walled nunnery), Vasari eloquently applied artistic inventiveness as well as historical, philosophical, and religious conceits. The painting was commenced in 1546 and completed in 1547 (Figs. 1-3). ${ }^{68}$

In contrast to the previous suppers, Le Murate Last Supper represents a monumental evocation of the event. In a palatial interior, Christ and the apostles are comfortably seated along an oval table, which has been lavishly garnished with an elaborate meal. Vasari's composition assimilated the Florentine Renaissance Last Suppers and the sentiments of the Reformation in Florence. ${ }^{69}$

Upon his return from Rome to Florence, after completing for Cardinal Alexander Farnese the Sala dei Cento Giorni in 1546, Vasari received a commission to paint a cenacolo from a relative of Pope Paul III (Alessandro Farnese, 1458-1549), Faustina di Vitello Vitelli (d. 1584), a nun residing in Le Murate. ${ }^{70}$ The pope paid for the Last Supper because of the poverty vows of the order and their lack of funds. Vasari recounted the commission in ricordo 167, 13 November 1546:

La abessa e monache delle Murate di Firenze mi allogorono un cenacolo di grandezza di braccia 13 di legniame largo, alto braccia tre e mezzo, diviso in cinque pezzi; quale io dovessi farlo in Fiorenza per presso et pagamento di $\Delta$ cento di y sette. Il quale acordo feje [fece] Giovan Maria Benintendi di casa messer Ottaviano de' Medici, et cosi promessi lavorallo a olio et finillo con diligentia fra sei mesi prossimi.

[The abbess and the nuns of Le Murate of Florence commissioned a cenacolo with the measurement of 13 braccia in length and 31/2 in height, divided in five parts; to be painted in Florence for the cost and payment of one hundred and seventeen [scudi]. This agreement was made by Giovan Maria Benintendi from the household of Ottaviano de' Medici. And as such I promised to paint in oil and finish it with diligence within the next six months. $]^{71}$

68 See Härb, The Drawings of Giorgio Vasari, 284-285, for an account of this commission.

69 See Antonio Paolucci, "Opere d'Arte," in Arnaldo d'Addario, ed., La Comunità Cristiana Fiorentina e Toscana nella Dialettica Religiosa nel Cinquecento (Florence: Becocci, 1980), 197-201, for an examination of the function of the Council of Trent, the Tridentine Reform, and the transformation occurring in art regarding the vision of interpreting the religious texts in a manner to be understood by the faithful as well as integrating the devotee into the visual narrative through participation in it.

70 The cloistered nuns, known as Le Monache delle Murate or Le Murate [the walled up], lived in small cells on the old Ponte Rubaconte [Rubaconte Bridge], which was built in 1237. In 1290 numerous wooden structures were built on the bridge, including shops and tabernacles, which later became chapels. One of these chapels was named Santa Maria delle Grazie. When the Rubaconte Bridge was restored, the name was changed to Ponte delle Grazie [Bridge of the Graces], in recognition of the religious chapels on the bridge. Hermitages were also constructed along the bridge and later turned into small cells for Le Murate. The bridge constantly flooded, and in 1320 Le Murate were forced to relocate to drier premises such as the private or public religious buildings on the nearby via Borgo Pinti and via Ghibellina. Le Murate remained in these buildings until the Renaissance. See Sharon T. Strocchia, Nuns and Nunneries in Renaissance Florence (Baltimore: Johns Hopkins University Press, 2010, repr. 2013), for a study on the transformation of Florentine religious convents in the fifteenth century; S. Weddle, "WWomen in Wolves' Mouths': Nuns' Reputations, Enclosure and Architecture at the Convent of Le Murate in Florence," in Architecture and the Politics of Gender in Early Modern Europe, ed. Helen Hills (Aldershot: Ashgate, 2003), 115-129, for a study on the monastery; K. J. P. Lowe, "Female Strategies for Success in a Male-Oriented World: The Benedictine Convent of Le Murate in Florence in the Fifteenth and early Sixteenth Century," Studies in Church History 27 (1990): 209-221, 218, for a study on the convent and its patronage; and Enrica Viviani Della Robbia, "Note e notizie sul Cenacolo del Vasari per il monastero delle Murate di Fiorenza," in Studi Vasariani (Florence: Sansoni, 1952), 220-226, in particular 222, specifically on the nuns' patronage for Vasari's commission. These sources discuss two possible nuns and one of the pope's relatives for the commission. Viviani proposed and documented in 1952 the name of Faustina di Vitello Vitelli. Recently, Lowe advocated for Lelia Orsini or Elena Orsini, whereas Weddle noted the important role of Faustina di Vitello Vitelli in the convent. The name of Gianna di Bernardo Bonsi was suggested as a resident abbess of Le Murate perhaps involved with the commission as well. See n. 75 below.

71 See Frey, Der literarische Nachlass Giorgio Vasaris, 2:865, no. 167; and Härb, The Drawings of Giorgio Vasari, 284-285, for the recent literature on this commission and illustration of the drawings and surviving panels. 
Vasari's Le Murate Last Supper has suffered many vicissitudes since its completion but miraculously has survived. This huge religious painting of $81 / 2$ feet x $221 / 2$ feet was restored in 1593 and again in 1718. It is unclear when the Italian inscriptions in the tablecloth, located in the lower center of the painting, were added and by whom; perhaps the first restorer in 1593 inscribed: "Cavalier Giorgio Vasari Aretino/Dipinse Questa Opera L'Anno/MDXXXXVI-Restaurata L'anno MDLXXXXIII" and the second restorer, continuing on the same lower line of the first inscription, added in 1781 the second inscription: "Di Poi L'anno MDCCXVIII" (Figs. 1a, 1b, and 1c). ${ }^{72}$

Years later, when the convent of Le Murate was suppressed, the painting was moved to the Chapel of the Sacramento in Santa Croce. On 4 November 1966, the Vasarian masterpiece suffered severe, nearly irreparable damage during the Florentine alluvium (flood). From that time until now it has been in the Museo dell'Opera of Santa Croce awaiting restoration. Now, fifty years later, Vasari's Last Supper has been magically restored by a group of masterful technicians, artists, and scientist. ${ }^{73}$

Vasari's commissions to depict Last Suppers in refectories are as numerous as are their thematic interpretations. But the traditional religious theme of the Last Supper in the Refectory of the Monastery of the Murate proclaims Vasari's maniera style and new iconographical conceits. ${ }^{74}$ Although we may expect in this Last Supper a more conventional imagery because of the patronage of a female and poor religious order, ${ }^{75}$ the contrary is true. Vasari composed an extraordinary, monumental, and imposing religious structure for the nuns' dining hall at Le Murate, staging the thanksgiving meal as theatrical scene. As stage curtains are metaphorically drawn, the following is revealed: an interior setting of an elegant, palatial, Renaissance sala da pranzo (dining hall) where the sacred drama is evolving. The unveiled scene presents twelve apostles seated at an oval table framing Christ, who is seated in the place of honor. The center of the scene shows Christ's blessing and the apostles' awareness of their future predicament indicated in the inscription: Hoc facite in mean commemorationen [Do this in remembrance of me].

Vasari completed several drawings for this commission. Recently, Florian Härb attributed a significant sketch for the Last Supper. The study is a design in pen and brown ink, brown wash, over black chalk at the British Museum (inv. Sloane 52.36-134). ${ }^{76}$ This early study for Le Murate Last Supper shows an elegant architectural background similar to those executed in the refectories of San Michele in Bosco (Christ in the House of Martha, 1540) in Bologna and Monteoliveto in Naples (Christ in the House of Simon, 1545). ${ }^{77}$ Niches and small blind windows are framed by descending staircases on each side of the central scene of an

\footnotetext{
${ }_{72}$ My gratitude is extended to Prof. Yael Even of the University of Missouri at Saint Louis for these photographs.

73 Among many newspaper articles, see Deitz, "50 Years After the Flood." In 1588, Ferdinando I de' Medici founded a conservation center for the care of hard stones and other artifacts.

74 The Staaliche Graphische Sammlung in Munich owns a drawing of Vasari's Last Supper (no. 2271) for Le Murate refectory. The drawings help to reconstruct the composition of the original painting, now in segments, to be restored by the Florentine Commission for Restoration.See Viviani Della Robbia, "Note e notizie sul Cenacolo del Vasari per il monastero delle Murate di Fiorenza," 220-226. See also Frey, Der literarische Nachlass Giorgio Vasaris, 2:865, Ricordo no. 167 dated 13. XI.1546 (with a notation by nun Sor Giustina Niccolini of 1597). The ricordo states that in 1546 Sister Faustina di Vitello Vitelli, in order to enter the monastery, donated to the convent a Last Supper, which today hangs in the refectory, executed by the excellent painter "Maestro Giorgino Aretino [Vasari], one of the most renowned and famous masters from that city." The ricordo continues to describe how the painting was praised for its originality and beauty, thus creating a moving devotional image. It also highlights Vasari's charitable action of charging only 117 scudi for his services in this respect instead of the customary 300.

75 See Strocchia, Nuns and Nunneries in Renaissance Florence, passim; and Douglas N. Dow, Apostolic Iconography and Florentine Confraternities in the Age of Reform (Burlington, VT: Ashgate, 1988).

76 See Härb, The Drawings of Giorgio Vasari, 284, Fig. 132.

77 See Cheney, "Vasari and Naples," 52-53; and Härb, The Drawings of Giorgio Vasari, 174-175.
} 
oval table with the protagonists of the Last Supper. Judas is placed in the tradition of the early Florentine Last Suppers, opposite and on the right side of Christ, while John faints in the arms of Christ on the left side as well. It is interesting to observe that Vasari included thirteen apostles at the table along with Christ. Perhaps he was vacillating about where to place Judas at the event, designing two possible situations, one sitting across from Christ and the other on the same side of Christ. The table is covered with a tablecloth but lacks place-settings and culinary ingredients. No visible preparations for the supper are seen, except for two sketched vases located on the floor and adjacent to Judas.

The second study for Le Murate Last Supper is a beautiful drawing, pen and brown ink, brown wash, over black chalk squared in black chalk (9 $1 / 4$ feet x 18 1/4 feet) at the Staaliche Graphische Sammlung in Munich. ${ }^{78}$ Vasari demonstrated his virtuosity as a designer and visualized what he meant by the importance of disegno [drawing] as the first artistic conception in the realization of a painting. This disegno provides an understanding of the unity of the composition, movement, and expression expressed in the original painting when it was delivered to Le Murate. After natural mutable traumas and restorations, we today can see evidence that the painting was done in five sections, following the commission's instruction that it be "diviso in cinque pezzi" [divided into five parts]. The contract for the commission required that the painting be composed outside of the convent because of the nunnery rules that no males could enter the convent's premises; hence, because of the great size of the painting, Vasari had to partition it. His disegno demonstrates his artistic maturity and conception of the maniera style, where the fusion of the artist's visualization (idea) revealed in a physical construct (disegno) manifests a beautiful conceit (a work of art).

Le Murate Last Supper is a religious visual poem whose words and images express a thanksgiving celebration and invite the viewer and the artist to the table to participate in this miraculous feast. ${ }^{79}$ Unlike the previously discussed Florentine Renaissance Last Suppers, Vasari, for the first time, provided an obvious place-setting for an anonymous devotee to interact with the apostles and, hence, directly benefit from Christ's blessing. This is an allegorical place-setting for the nuns of the convent, who, attending an actual daily meal in the refectory, are visually and spiritually invited to partake of Christ's thanksgiving gift. Large vessels or vases and jugs of wine are depicted in front of the table in lieu of an apostle's setting adjacent to the viewer. The association of Vasari's name, vasaio [vase or vessel], with vases is not the only indication of his participation. Excluding the obvious point, that Vasari painted this religious scene, in the Munich drawing, it is possible to see his signature in the right hand corner. ${ }^{80}$ Vasari also inserted an additional place-setting for himself. As a Christian participant in this solemn event, in the drawing as well as in painting, Vasari too, as a devotee, wanted to partake of the apostles' blessings. As an artist and creator of art, he saw himself an imitator of God's creation; ${ }^{81}$

78 See Härb, The Drawings of Giorgio Vasari, 2-19, on the theory and practice of Vasari's drawings; and Liana De Girolami Cheney, "Giorgio Vasari's Fine Arts from the Vite of 1550: The Splendor of Creativity and Design," Journal of Literature and Art Studies 7, no. 2 (February, 2017): 1-40.

79 See Pitre, Jesus and the Last Supper, 450-452, for an allusion to a heavenly or eternal banquet.

${ }^{80}$ The present signature, Giorgio Vasari, and date 1546, plus the notation of the further restorations in 1583 and 1718 , are later additions to the painting.

${ }^{81}$ See Cheney, "Giorgio Vasari's Fine Arts from the Vite of 1550," 1-40. Vasari's concept of creativity originates in God, to whom Vasari refers as "Divine Architect of Time and of Nature" in the First Preface of the Vite (Bettarini-Barocchi, Preface One, 2:4):

Cosi, dunque, il primo modello onde uscì la prima imagine dell'uomo fu una massa di terra; e non senza cagione, perciò che il divino Architetto del tempo e della natura, come perfettissimo, volle mostrare nella imperfezzione della materia la via del levare e dell'aggiungere, nel medesimo modo che sogliono fare i buoni scultori e pittori, i quali, ne' lor modelli, aggiungendo e levando riducono le imperfette bozze a quelle fine e perfezzione che vogliono. 
and as a Christian, he wished to receive Christ's thanksgiving and partake of the Christian salvation.

The construction of the overall design of the drawing and painting is complex, with an interlocking concave and convex movement or combination of two semicircular shapes. ${ }^{82}$ The concave movement is a combination of a semicircular recession, a Christian basilica apse in the background. The convex movement is constructed by an inverted semicircular recession - a projection - into the space of the viewer in the foreground. When unified, these semicircular movements form the illusion of a Roman amphitheater, the Vespasian Coliseum of $70 \mathrm{CE}$. In between these two semicircular formations hangs a rectangular form: a horizontal tapestry where the narrative unfolds. Another architectural metaphor is the analogy between the arena of a Roman amphitheater, where Christians were slaughtered, and Vasari's compositional setting for Christ to become a sacrificial lamb.

Rome was a special city for Vasari, and not just because of its classical past and architectural beauties, which he recounts in his vita (autobiography) and in the vita of his Florentine friend Francesco de' Rossi Salviati (1510-63) where he describes how they spent hours drawing everything they saw in the eternal city as well as the works of Raphael and Michelangelo. ${ }^{83}$ Rome had also provided for Vasari an intellectual connection with the papacy as well as important artistic commissions. Upon returning from Rome in 1546 after working for the Farnese family, Vasari undertook Le Murate Last Supper commission in Florence.

The design of the painting is further divided into three parts horizontally: background with an elaborate architecture; middle ground with the meal scene; and foreground with the empty space, the edge of the painting, and the Latin inscription, visible in the drawing but not in the painting. The architectural background in the shape of semicircle is also composed of three parts. At the middle level, a large wall in a square u-shape supporting a classical column contains in the center a large attic and a Latin inscription: Hoc facite in mean commemorationen [Do this in remembrance of me] - a powerful proclamation of an everlasting covenant between Christ and His apostles and God and the faithful. ${ }^{84}$ On each side of the wall are also large scrolls, whose inscriptions are not legible. In the back of this wall, two openings form a curved balustrade, where figures are standing and carrying plates. Probably these are the servants waiting to serve or attend to the needs of the guests. Through the openings of the balustrade, the vision of a sky with a setting sun suggests early evening, the time of the supper. The overall architectural display recalls the curvilinear steps and balustrade in the virtuoso Michelangelo's ricetto (anteroom) of 1524 for the Laurentian Library in Florence; and Vasari's own architectural constructions in the

[Now the material in which God worked to fashion the first man was a lump of clay, and this was not without reason; for the Divine Architect of time and of nature, being wholly perfect, wanted to show how to create by a process of removing from, and adding to, material that was imperfect in the same way that good sculptors and painters do when, by adding and taking away, they bring their rough models and sketches to the final perfection for which they are striving].

${ }^{82}$ Vasari will repeat this type of complex architectural design in the drawings and paintings for The Wedding of Esther and Ahasuerus of 1548 for the Badia di SS Flora e Lucilla in Arezzo, now in the Museo Statale d'Arte Medievale e Moderna in Arezzo. See Corti, Vasari, 54, for the image; and Härb, The Drawings of Giorgio Vasari, 284-295, for three drawings of The Wedding at Cana of 1564-1566, commissioned for the refectory of the Benedictine Monastery of San Pietro in Perugia. See Härb, The Drawings of Giorgio Vasari, 331-334, and 511, for the four known drawings and the painting of 1566 in Budapest Museum of Fine Arts, Budapest, Hungary. See also Leon Satkowski, Giorgio Vasari: Architect and Courtier (Princeton: Princeton University Press, 1993), 47-52, 94-96, and 106-112, for a study on ancient architecture and topography in Vasari's architecture.

${ }^{83}$ See Bettarini-Barocchi, Vite, 5:512 and 515, on Vasari's Salviati vita.

${ }^{84}$ See Pitre, Jesus and the Last Supper, 90-100. 
paintings of the Sala dei Cento Giorni of 1546 in the Palazzo della Cancelleria in Rome. ${ }^{85}$

In the center of the composition where the meal is taking place, the apostles are seated around an oval table. Vasari, under the influence of Leonardo, arranges the apostles reacting to Christ's words about betrayal into groups around the table but with the formation of reversed triangles. A possible composition of groups of three would form five inverted triangles. The first three figures on the left side of the table form the first triangle. An apostle pulling on Peter's toga for attention, Peter holding a knife, and Judas hiding a moneybag compose the second triangle. Christ's blessing gesture with His hand performs a dual action of blessing and stopping Peter's bellicose action, while with His right arm He embraces John, who has fainted in the Lord's arms. The third member of this group is the viewer, who occupies the open place in front of Christ, forming the third triangle. The next geometrical composition of the fourth triangle is composed of Thomas pointing at Christ while turning to another apostle and including the metaphorical personification of Vasari through the collection of vessels located across the table from the two apostles. The last triangle is comprised of three apostles located at the right end of the table. Therefore, Vasari's configuration and geometric construction figuratively follows the requirement of the contract that the composition be designed in five parts.

Another possible composition would be the creation of three clusters of five groups. Two clusters formed by a group of five apostles, located at the end of each side of the table, framing ardent Peter, ponderous Christ, and fainted John at the center of the table. The viewer partaking of the empty place-setting in front of Christ and Vasari's metaphorical placement at the table completes a third group of five people. But Vasari's imaginary presence could also be affiliated with the apostles at the right-hand end of the table.

When comparing the Munich drawing with the painting, there are two significant changes: one is related to the style; the other to the content. The stylistic change is seen in the grouping of the apostles on the left side of the table, where the apostle pulling Peter's garment is an elderly man and the young apostle, on the extreme left of the group, tenderly embraces his fellow companions. Hence more gestures of affection are revealed in the drawing than in the painting. The other difference is associated with differences in the Latin inscriptions, addressed earlier in this essay. ${ }^{86}$

In both his drawings for Le Murate Last Supper and in the painting itself, Vasari continued the Florentine tradition of depicting the apostle John fainting at the table on the right side of Christ and the apostle Judas seated opposite and on Christ's left side. Interestingly, Judas is painted turning his head away from Christ and toward the viewer, who notices Judas reaching for his moneybag with his left hand and his uncertainty of what to grasp with his right hand - the bread, the wineglass, or the long knife? In the Munich drawing, there are no visible knives placed on the table; this was Vasari's maniera conceit for the painting.

In the composition of Le Murate Last Supper, Vasari revealed the Florentine dilemma of the Reformation and the Tridentine sentiment. Antonio Paolucci, in the introductory essay on the Florentine Religious Reformation in L'Opere d'Arte, clearly noted that the Cinquecento Florentine Reformation was an integration of the Lutheran Reform with Tridentine Christianity for the purpose of "restoring the seriousness and awareness of the Scriptures and Christian teachings, which seemed to have been lost or at least obfuscated, to the faithful." 87

\footnotetext{
85 See Freedberg, Painting in Italy, 1500-1600, 309; and Claudia Conforti, Giorgio Vasari architetto (Milan: Electa, 1993), 7-38, on Vasari's architectural construction.

86 See nn. 4 and 5.

87 See Paolucci, "Le Opere d'Arte," 200: "[Riforma]si e trattato del recupero di una serità e di un consapevolezza che sembravano se non perdute almeno offuscate, di uno sforzo vasto e diffuso per ritrovare nella Scrittura e nel Magistero, ma anche nei sentimenti e nelle attese dei credenti le ragioni per fare arta sacra." See also Simon Ditchfield, Liturgy, Sanctity and the History of the Tridentine in
} 
Hence the Church's quest to reform and explain the importance of commissioning and supporting the creation of sacred art. But the Tridentine movement for Paolucci, lacked manifesti and aesthetic rules, thereby allowing for artistic license. ${ }^{88}$ The religious communities and private devotees in collaboration with artists and the Christian Church were able to come to an agreement about the Christian reforms. ${ }^{89}$ This type of partnership granted the artists freedom in their creativity, as seen in Vasari's Le Murate Last Supper, where he combined Tridentine and the Reformation notions about representations of the Last Supper. The Tridentine tradition kept Latin inscriptions in the imagery; included bread, wine, and half-eaten lamb on the table; and focused on Christ's thanksgiving as well as His being a sacrificial lamb (Crucifixion). The Reformation (Lutheran) tradition stressed the important of Christ's Resurrection, discouraging the placement of food on the table as seen in Albrecht Dürer's late woodcuts of the Last Supper, which Vasari knew through prints. ${ }^{90}$

Several aspects in Le Murate Last Supper allude to Christ's Crucifixion as well. The central vertical movement interlocks with a strong horizontal movement, thereby symbolizing the upper part of a Latin cross or a crossing in a Christian church. Judas's betrayal announced at the messianic banquet, his action of hiding his moneybag, and the knife next to his place-setting pointing at Christ forecasts doom-Christ's Crucifixion. The symbolism connected with the placement of the knife next to Judas refers to his origin as a Zealot and belligerent rebel known as a sicarius, a dagger-man. ${ }^{91}$

With the composition of the table and its ingredients, Vasari continued the Christian tradition of the symbolism of the bread, wine, and lamb as offerings of thanksgiving. But what is unusual among the edible substances at the table is the addition of salt. Bread and salt were ancient offerings of hospitality and a covenant of fidelity. There are numerous references in the Bible to the significance of salt in a meal. The Old Testament Mosaic Law required that all offerings contain salt, since salt was used to flavor and preserve food (Lev. 2:14). In the New Testament, Christ mentioned the word salt when referring to His apostles as the "salt of the earth"

Italy (Cambridge: Cambridge University Press, 1995); Keith P. Luria, “Popular Catholicism' and the Catholic Reformation," in Early Modern Catholicism: Essays in Honor of John W. O'Malley, S.J., ed. Kathleen M. Comerford and Hilmar M. Pabel (Toronto: The University of Toronto Press, 2001), 114-116; Salvatore Caponetto, The Protestant Reformation in Sixteenth-Century Italy (Kirksville, MO: Truman State University Press, 1999); and Lynette M.F. Bosch, “Orthodoxy and Heterodoxy in Agnolo Bronzino's Painting of Bartolomeo and Lucrezia Panciatichi," in Agnolo Bronzino: Florentine Muse, ed. Liana De Girolami Cheney (Washington, DC: New Academia, 2014), 35-134, for a careful study on the impact of the Reformation on Florentine patronage, including an examination of Bartolomeo and Lucrezia Panciatichi's patronage of the painter Agnolo Bronzino (1503-1572), Vasari's contemporary. The Panciatichi were sympathizers of Luther's Reformation reflected in the writings of the monk Benedetto di Mantova's Beneficio di Cristo (Venice: Andrea Arrivabene, 1543). His successful and popularized publication emphasized the doctrine of justification through faith, the complete dependency on Christ for an individual's salvation.

88 See Paolucci, "Le Opere d'Arte," 200.

89 See Paolucci, "Le Opere d'Arte," 220. During the post-Tridentine movement in Florence at the time of the episcopate of Alessandro Ottaviano de' Medici (1535-1605), female religious organizations continued to prosper. See Strocchia, Nuns and Nunneries in Renaissance Florence, 194.

90 Dürer's prints were also a source of inspiration for Vasari's artistic teachers such as Leonardo, Raphael, Rosso, and Pontormo. See Kristina Hermann-Fiore, "Sui rapporti tra l'opera artistica del Vasari e del Dürer," in Atti del Convegno Il Vasari Storiografo e Artista (Florence: Istituto nazionale di studi sul Rinascimento, 1976), 701-715; Craig Härbison, "Dürer and the Reformation: The Problem of the Re-dating of the St. Philip Engraving," Art Bulletin 58, no. 3 (September 1976): 368, on Dürer and Martin Luther; and Erwin Panofsky, The Life and Art of Albrecht Dürer (Princeton: Princeton University Press, 1952), 218, for a discussion on the Last Supper's woodcut and Dürer's plan to compose an oblong composition for the Passion series. Panofsky noted the influence of Leonardo's Last Supper as well as Raimondi's engraving after Raphael's Last Supper from Dürer's composition. See David Price, “Albrecht Dürer's 'Last Supper' (1523) and the 'Septembertestament,"” in Zeitschrift für Kunstgeschichte 9. Bd., H. 4 (1996): 578-584; and Gregory, Vasari and the Renaissance Print, 163-164, on Leonardo and Dürer; 170-171, on Raphael, Raimondi, and Dürer; 183-185, on Rosso, Pontormo and Dürer; and 197, on Vasari and Dürer.

91 See J. C. J. Metford, A Dictionary of Christian Lore and Legend (London: Thames and Hudson, 1983), 149. 
(Matt. 5:13). This statement has two meanings. Metaphorically, Christ is making a "covenant of salt" with the apostles according to Mosaic notions of fidelity, hospitality, and resilience (Lev. 2:13; 2 Chron. 13:5). Hence the apostles are making a covenant with God that, if broken, would bring perilous consequences (Mark 9:50). Similar to the analogy of salt, if food is not prepared with salt, it not only loses its flavor but also can easily become contaminated and corrosive (Matt. 15:13-14), just as Judas, who lacked in God's faith, therefore floundered and betrayed Christ. The other signification refers to the use of salt for purification at sacrificial offerings and as prevention against evil (Ez. 16:4). ${ }^{92}$ In his Le Murate Last Supper, Vasari depicted two containers of salt along with the other edibles, emphasizing Christ's ministry "a covenant of salt" with His apostles; however, although one of them is next to Judas's place-setting of bread and wine, a knife rests between the break and the salt, alluding to Judas's breaking the pact with God, becoming impure, and violating the laws of divine hospitality (Matt. 5:13; Mark 9:5). ${ }^{93}$

The placement of these edibles on the table, which is covered with a linen cloth, augments the symbolism of sacrifice. The table was an ancient symbol of an altar that in Christianity becomes an altar upon which the ritual sacrifice of the mass will be enacted with sacramental bread and wine. The white linen tablecloth is an Old Testament prefiguration of Christ's burial cloth or sudarium, in which Joseph of Arimathea wrapped Christ's body before placing it in His tomb after the Crucifixion (Luke 23:53; John 19:38-40; Matt. 27:59-60; and Mark 15:46). ${ }^{94}$ Thus, in the painting, Vasari composed a preamble and analogy to Christ's Crucifixion. However, Vasari's depiction of the viewer/faithful's participation in the Eucharistic meal, even if metaphorical, suggests his confirmation and resolution in combining the two religious approaches - the Protestant view of the Last Supper as the Resurrection of Christ or restoration of life, and the Tridentine view of Christ's Last Supper, which is profoundly intertwined with Christ's death, as a symbol of salvation and thanksgiving. This religious conceit is a combined Passover meal and Eucharistic meal foreshadowing Christ's own approaching death. ${ }^{95}$ His death will bring salvation to the believers. ${ }^{96}$ Vasari emphasized Christ's vow at the Last Supper: Hoc facite in mean commemorationen [Do this in remembrance of me].

When the hour came, Jesus and his apostles reclined at the table. And he said to them, "I have eagerly desired to eat this Passover with you before I suffer. For I tell you, I will not eat it again until it finds fulfillment in the kingdom of God." After taking the cup, he gave thanks and said, "Take this and divide it among you. For I tell you I will not drink again from the fruit of the vine until the kingdom of God comes." And He took bread, gave thanks and broke it, and gave it to them, saying, "This is my body given for you; do this in remembrance of me." In the same way, after the supper He took the cup, saying, "This cup is the new covenant in my blood, which is shed for you" (Luke 22:14-20). ${ }^{97}$

\footnotetext{
92 The biblical tradition required children to have their umbilical cord cut at birth and cleaned with salt to prevent infections. In Christian baptism, a child is blessed with salt, recalling the birth's protection against contamination (Ezek. 16:4).

93 See Metford, A Dictionary of Christian Lore and Legend, 218. During the early Christian period, adults receiving baptism in the catacombs were provided with piece of salted bread before the ceremony as a sign of welcome into the house of God.

94 See Bible, New International Version (NIV, public domain), Luke 23:53: "Then he [Joseph of Arimathea] took it down, wrapped it in linen cloth and placed it in a tomb cut in the rock, one in which no one had yet been laid." See also Pitre, Jesus and the Last Supper, 358.

95 See Pitre, Jesus and the Last Supper, 483-488, on Christ's vow at the last banquet and the connection between the Passover and the Crucifixion.

96 See Pitre, Jesus and the Last Supper, 170 and 240-241, for salvation through Christ's death.

97 See Bible, New International Version (NIV, public domain).
} 


\section{Coda}

Two years after the completion of Le Murate Last Supper, Vasari painted the most lavish representation of a biblical feast, The Marriage of Esther and Ahasuerus (signed and dated Georgius Vasarius Aretinus Faciebat A.D. MDXLIX), ${ }^{98}$ for the refectory of the Badia SS. Flora e Lucilla in 1548-49 in Arezzo. It was executed on site because of its impressive physical size ( 9.2 feet $\times 24$ feet, Fig. 22). This majestic painting was also moved several times from the original refectory and at present is located in the Museo Statale d'Arte Medievale e Moderna in Arezzo. Vasari completed numerous drawings for this painting, which can be found at the Städelsches Kunstinstitut in Frankfurt and the Gabinetto dei Disegni e delle Stampe at the Uffizi (numbers 719E, 647F, and 649F). ${ }^{99}$ The banquet scene takes place in a luxurious interior where magnificently dressed figures participate in the wedding celebration. For the architectural setting, grouping of figures, figure types, maniera treatment of the figures, and display of ornamental objects (vases), Vasari quotes and borrows from his previous paintings on this theme, such as: Christ in the House of Martha and Mary (1539-41); ${ }^{100}$ The Feast of St. Gregory (1539-40); ${ }^{101}$ Abraham and The Angels (1540) painted for the refectory of San Michele in Bosco in Bologna (now Istituto Ortopedico Rizzoli); ${ }^{102}$ The Fall of the Manna (1544) ${ }^{103}$ and Christ in the House of Simon (1544), both painted for the refectory of Sant'Anna di Monteoliveto (or Sant'Anna dei Lombardi) in Naples; ${ }^{104}$ and The Wedding at Cana (1545-50). ${ }^{105}$ In The Marriage of Esther and Ahasuerus in Arezzo,

\footnotetext{
98 Frey, Der literarische Nachlass Giorgio Vasaris, 2:867, Ricordo 182; Corti, Vasari, 76; Leone de Castris, "Napoli 1544: Vasari e Monteolivelo," in Bolletino d'Arte 66 (1981): 59-88, especially 63; and Barocchi, Vasari Pittore, 120 and 131. Vasari illustrates the biblical passage from the book of Esther 4 and 5, and also the Apocryphal book of Esther, 15.

99 See E. Parma Armani, "Fonti per il 'Convito per le nozze di Ester e Assuero' di Giorgio Vasari in Arezzo," Studi di storia delle arti 3 (1980): 61-75. See Härb, The Drawings of Giorgio Vasari, 68, Fig. 58, for the drawing at Städelsches Kunstinstitut, Frankfurt (No. 141); 294-296, for the recent literature on this commission and illustration of the drawings.

100 See Milanesi-Vite, 7:664. "Being employed in 1539 to do three panels in oils, with a frieze, and twenty subjects of the Apocalypse in small figures, with grotesques and festoons for the monks of Monteoliveto, in their monastery of San Michele in Bosco, outside Bologna, at the end of a refectory." See Archivio di Stato di Bologna, Libri delle Fabbriche: Olivetani in San Michele in Bosco, Book 4; Carte 5:38; 5:39; and Härb, The Drawings of Giorgio Vasari, 174-175, for the recent literature on this commission and illustration of the drawing and painting.

101 Throughout the Renaissance, a plethora of Gregorian legends circulated about the various miracles of the Host and the Mass of Saint Gregory, in which Christ appears as the Eucharistic Man of Sorrows, because Saint Gregory had played a significant role in the development of the Roman doctrine of the Mass and liturgy. See Schiller, Iconography of Christian Art, 2:32 and 226; and Härb, The Drawings of Giorgio Vasari, 178, for the recent literature on this commission and illustration of the drawing and painting.

102 See Härb, The Drawings of Giorgio Vasari, 176-177, for the recent literature on this commission and illustration of the drawings. A painting on the same subject done in 1550 is in the cenacolo of San Salvi. See Corti, Vasari, 88.

${ }^{103}$ See Härb, The Drawings of Giorgio Vasari, 258-259, for the recent literature on this commission and illustration of the drawings and surviving panels.

104 See Milanesi-Vite, 7:674-675:
}

When I arrived I felt inclined to refuse the work, as the building is Gothic, low and dark, so that I feared the work could bring me little credit ... Considering it hopeless without a great profusion of ornament, as numerous figures would confuse the spectator, I decided to cover the vaulting with stucco, and get rid of the old-fashioned awkward sections by making rich compartments in the modern style ... I was able to carve my squares, ovals and octagons ... This stucco-work was divided into three parts: one for Faith, the second for Religion and the third for Eternity. Each of these is accompanied by eight Virtues, to show the monks eating there what is required of them. I enriched the spaces of the vaulting with grotesques, forming a framework for the forty-eight celestial images.

See also Alessandro del Vita, II Libro delle Ricordanze di Giorgio Vasari (Arezzo: Fratelli Zelli, 1938), 41-61; Archivio di Stato di Napoli, "Monasterio di Monteoliveto," vols. 5504, 5529, 5532, 6033, and 6035; and de Castris, "Napoli 1544: Vasari e Monteoliveto," 59-88. See Härb, The Drawings of Giorgio Vasari, 260-261, for the recent literature on this commission and illustration of the drawings and surviving panels.

105 Vasari completed the Marriage at Cana in 1566 for the San Pietro Benedictine Monastery in Perugia, now at the Szépmúvészeti Múzeum in Budapest. See Barocchi, Vasari Pittore, 139, for a discussion and comparison on two drawings on the 
Vasari culminated his quest for the creation of a supper theme with maniera conceits and style, while with his monumental masterpiece of Le Murate Last Supper, he captured the religious fervor and piety of Christianity in the Cinquecento.

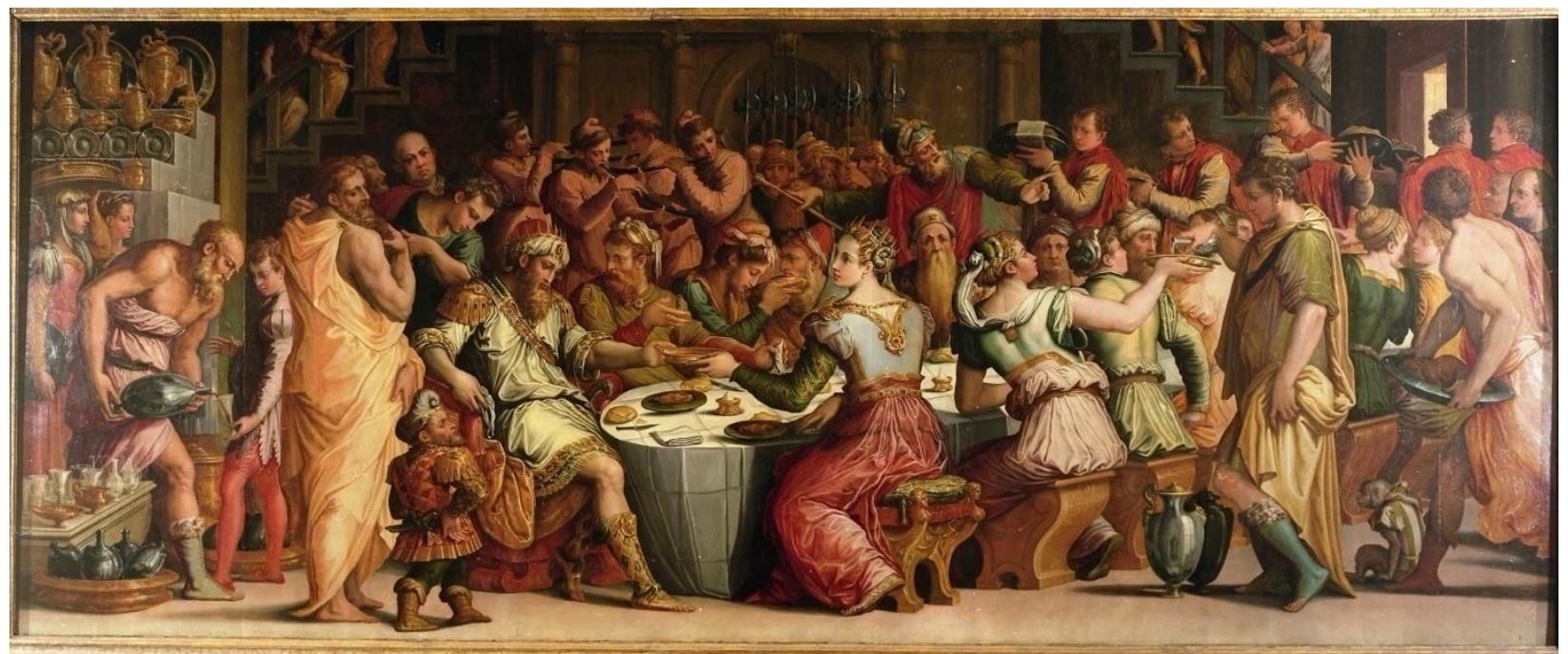

Figure 22. Giorgio Vasari, The Marriage of Esther and Ahasuerus (signed and dated Georgius Vasarius Aretinus

Faciebat A. D. MDXLIX. Museo d'Arte Medievale e Moderna, Arezzo. Photo credit: Foto Tavanti, Arezzo.

Vasari continued to be fascinated with this religious theme of the Last Supper during 1567 and 1569, when he completed two other small devotional paintings on the subject. One was part of the art collection at his Florentine residence, and the other was a predella panel for the altarpiece in Santa Croce at Boscomarengo (Bosco Marengo). As noted in Serena Nocentini's essay on "Vasari's Last Supper of 1567-69" (now in the refectory of the Franciscan Oblate nuns at Figline and referenced henceforth as the Figline Last Supper; see Fig. 23), Vasari's painting originally was part of his art collection at Borgo Santa Croce. ${ }^{106}$ Vasari's inventory of assets included in his last will of 1574 notes: "Nella sala di sopra: [un] 1 quadro di braccia, entro un Cenacolo di mano del Signor Cavaliere [In the upper room: [there is one] 1 painting of one braccia, depicting a Last Supper done by the Honorable [Vasari]). ${ }^{, 107}$ In the event of lack of family heirs, Vasari's patrimony was to go to the Fratenita dei Laici. This Dominican order was very special for him. He had enrolled his sisters in the order and had supported their efforts and assistance to the infirm and people in need. ${ }^{108}$

subject at the Farnesina in Rome (no. 130642) and the other at the Albertina Museum in Vienna (no. 175). See also Härb, The Drawings of Giorgio Vasari, 29, 331-333, for recent literature on a commission and drawings of a Marriage at Cana at the Uffizi, Florence (inv. 7459F); and in a private collection. These drawings are in the shape of a lunette, unlike other drawings on the same subject in a rectangular shape at the British Museum, London (no. 132); Albertina Museum in Vienna (inv. 506); and a copy in Stockholm.

106 See Serena Nocentini, "Giorgio Vasari, Ultima Cena," entry in Arte a Figline: Da Paolo Uccello a Vasari, ed. Nicoletta Pons (Florence: Edifir, 2013), 140-142, for a discussion on the location of the commission. For further references on the painting, see Alessandro Cecchi, "Giorgio Vasari's Collection of Paintings: Its Provenance and Its Fate," in Vasari's Florence: Artists and Literati and the Medicean Court, ed. Philip Jacks (Cambridge: Cambridge University Press, 1998), 155; A. Conti, "La fabbrica, la chiesa, l'appartamento dei Signori," in Lo Spedale Serristori di Figline-Documenti e arredi, exh. cat. (Florence: Opus Libri, 1982), 77; Pons, Arte a Figline; and Corti, Vasari, 128.

107 See Vasari's Inventory (ARS.cod LVI.), printed in Frey, Der literarische Nachlass Giorgio Vasaris, 2:896.

108 See Bettarini-Barocchi, Vite, on Vasari's vita, 6:380. 


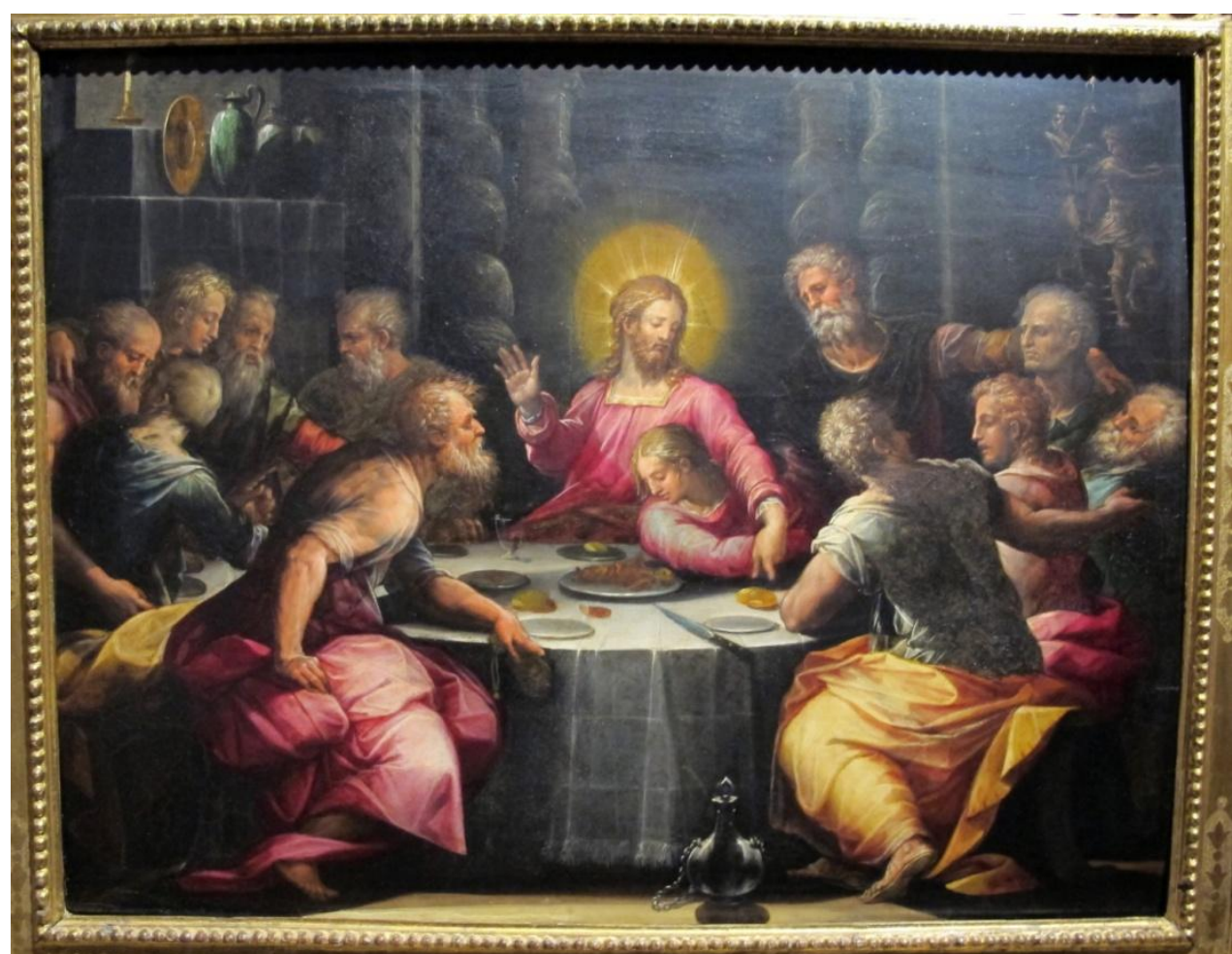

Figure 23. Giorgio Vasari, Last Supper, 1567-69. Refectory of SS Annunziata Hospital Serristori, Figline, Florence. Photo credit: Public domain. Wikimedia.org. Photographer: Sailko.

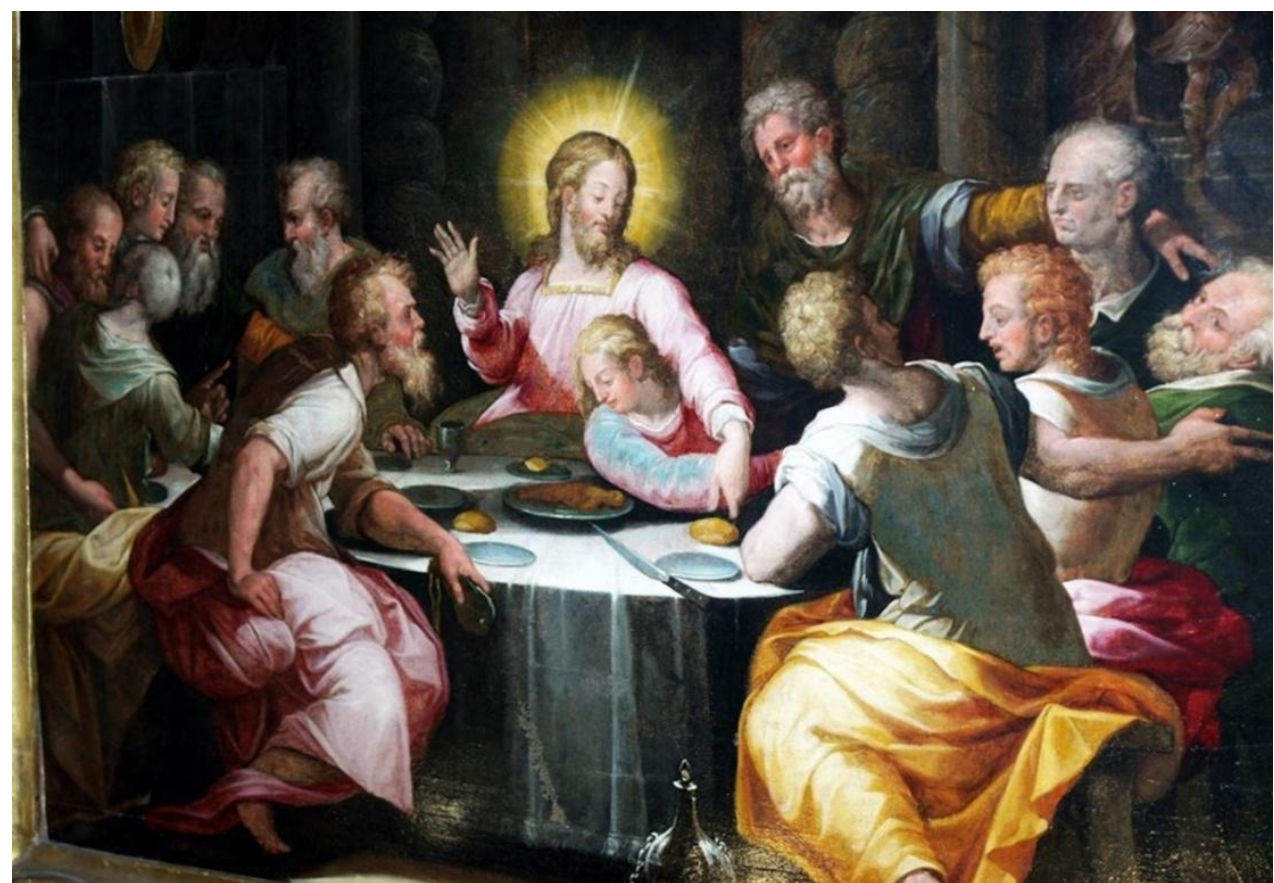

Figure 24. Giorgio Vasari, Last Supper, 1569. Museo of Santa Croce. Bosco Marengo (Alessandria) Piedmont. Photo credit: Museo di Santa Croce, Bosco Marengo, (Alessandria) Piedmont. 
It is unclear by whom and why the painting was sold for 30 lire on 25 November 1692 to the Hospital Serristori in Figline Valdarno. ${ }^{109}$ The hospital was founded in 1399 by Ser Ristoro di Jacopo Serristoro, a Florentine prior, to provide a site for the healing and recovery of pilgrims. In the fifteenth century, an apothecary was built in connection to the hospital area. The medical ingredients and herbal spices were placed in majolica containers made from the ceramists of Figline Valdarno. ${ }^{110}$ Vasari's painting was located in the refectory of the nunnery of the hospital dedicated to SS. Annunziata. He probably started working on this painting after his return from Rome in 1546, where he had completed the Sala dei Centro Giorni for Alessandro Farnese. ${ }^{111}$ In this Figline Last Supper, Vasari composed a scene that takes place during the evening within an elegant Roman interior. ${ }^{112}$ The background of the painting shows an apse with twisted Solomonic columns similar to those represented in several of his previous drawings and paintings: Christ in the House of Martha of 1539-40, for the refectory of San Michele in Bosco in Bologna; the drawing of Christ in the House of Simon of 1545, for the refectory of Monteoliveto in Naples; and Paul III Awarding Benefices on the Creation of Cardinals of 1546, in the Sala dei Cento Giorni, west wall, bay two, at the Palazzo della Cancelleria in Rome.

The apostles in the Figline Last Supper are seated around a circular table while experiencing Christ's thanksgiving blessing and the announcement of His betrayal. Judas is differentiated from the group by being represented with a voluminous toga wrapped around him and discretely hiding his moneybag below his plate. Only the viewer is able to see this action. Judas looks intensely at Christ, who ignores his gaze while focusing on His beloved John, who has collapsed on the table after hearing Christ's negative news. In the midst of the dark room, the scene is illuminated by Christ's radiant aureole forming a solar disk, a symbol of divinity and hope. ${ }^{113}$ Vasari constructed this lighting effect in two ways: physically to illuminate the dark room and shed light on the culinary objects and vases toward the left of the room, the arrival of servants with the food from the right opening of the room, and the reaction of the apostles. And spiritually, the light as a natural and divine source alludes to the glorious moment of thanksgiving and forgiveness of Christ as He raises His hand in blessing. The effect of light also points out a large wine vessel located on the floor in an axial direction to the table. The table contains the traditional edibles of the meal: bread, glasses with wine, and a dish with lamb. What is unusual on the table among the meal objects displayed is a very large knife, which is placed so that it points to Christ, as seen earlier in Vasari's Le Murate Last Supper. No other knife is visible except this instrument of betrayal and sacrifice, which alludes to the first betrayal and killing in the Old Testament, when

\footnotetext{
109 See Nocentini, “Giorgio Vasari's Ultima Cena," 19, citing the Archivio Storico dell'Ospedale Serristori Figline, no. 136, Registro Entrata e Uscita, giornale e quaderno di casa dello spedalingo, Giuseppe di Lorenzo Gigliozzi, 5/5/1688-1/4/1692. c. 183 r.

110 Figline had important associations for Vasari. It was the birthplace of the Renaissance Neoplatonic philosopher Marsilio Ficino (1433-1499), who was a significant influence not only for the Italian Renaissance culture but also for Vasari's own philosophical and symbolic ideas. It was a center for glass and pottery-making for the pharmacy of the hospital. The biccherai or glassmakers of Figline exported their glassware to Venice. Vasari's family was known for their pottery-making, hence his last name Vasari from vasaio (pottery-maker). And the hospital had a new loggia. The open gallery of the Figline's hospital was constructed in the sixteenth century based on five drawings by an unknown architect. This commission was paid by Romualdo da Settignano. However, initial construction did not occur until 2 December 1604. Perhaps Vasari had something to do with this architectural project, since the open archway is similar to the Brunelleschi's Hospital of the Innocents of 1401-1420 in Florence and Vasari's own logge. See Liana De Girolami Cheney, "Giorgio Vasari and Mannerist Architecture: A Marriage of Beauty and Function in Urban Spaces," Journal of Literature and Art Studies 6, no. 10 (October 2016): 1150-1171.

111 See Liana De Girolami Cheney, "Giorgio Vasari's Sala dei Cento Giorni: A Farnese Celebration," Exploration in Renaissance Culture 21 (1995): 121-151. Reissued for the 40th Anniversary of ERC Publication (Spring 2015).

112 See Cheney, "Vasari and Naples," 48-126.

113 See Hall, Dictionary of Subjects and Symbols in Art, 144.
} 
Cain killed his brother Abel, a prefiguration of the New Testament Crucifixion of Christ. ${ }^{114}$ Judas's behavior of evil sacrifice for his own pursuits is also prefigured in Cain's actions of mistrust, anger, and eventually killing. In this Last Supper, the physical depiction of the environment with the elegant setting, interior decoration, fancy tablecloth, and well-dressed apostles contrasts vividly with the spiritual implication of a brutal sacrifice and death, which will follow after the meal.

For Pope Pius V (Antonio Ghislieri, 1504-72), Vasari composed a large altarpiece (grande macchina d'altare) for the Church of Santa Croce at Boscomarengo (Bosco Marengo) between 1567 and $1569 .{ }^{115}$ The main theme is the Last Judgment, including numerous small paintings associated with biblical themes of meals that he had painted in previous years, such as The Sacrifice of Abel and Cain; The Fall of Manna; The Meeting of Abraham and Melchizedek; and Passover, including Christ's Last Supper. The Boscomarengo Last Supper is a variant of the Figline Last Supper, with a simpler compositional design, a less elaborate architectural interior, and a vibrant colorito (compare Figs. 23 and 24). ${ }^{116}$ In both of these small panels, Vasari returned to his earlier Last Supper's composition for Ottaviano de' Medici but emphasized the mystical moment of the religious event. $\mathrm{He}$ also dramatically incorporated the viewer's invitation to the table that he had so carefully depicted in the $L e$ Murate Last Supper, where between Judas and another apostle there is an open place-setting at the table, including a large knife pointed toward Christ and a jug of wine on the floor. In line with Reformation sentiments, Vasari is inviting faithful Christians such as himself to ponder on Christ's words.

\section{Conclusion}

In Le Murate Last Supper, Vasari captured the most pregnant moment of Christianity: the thanksgiving meal where Christ, in honoring His Father's wishes for humanity, sacrifices Himself but also will resurrect in celebration of eternal bliss, providing hope, love, and salvation for believers.

The incised Latin inscription in Vasari's Le Murate Last Supper announced Christ's message about the holy event, to be viewed by the participant nuns in the refectory at Le Murate convent. This inscription-Hoc facite in mean commemorationen [Do this in remembrance of me] - is a directive to and instruction for the Christian believer. Christ during the thanksgiving celebration instituted eternal bonds: He established a communion between His apostles and Christians; proclaimed His love toward humanity; and granted spiritual gifts of charity, faith, and hope for human's redemption through His Crucifixion (betrayal and death) and Resurrection. ${ }^{117}$

The Church's early focus on the Messianic or eukharistia meal or the offering of bread and wine was continued in the Florentine Renaissance. The eukharistia meaning of the Christian Last Supper emphasized Christ's divine role of granting spiritual benefits imparted through theological virtues (charity, faith, and hope), which combined with the natural virtues or the cardinal virtues (prudence, temperance, justice, and fortitude) to

\footnotetext{
114 "Cain hastened and rose up, and took the iron part of his ploughing instrument, with which he suddenly smote his brother and he slew him [Abel]" (Jasher 1:25). Hence a large knife is a symbol of slaughtering a victim offered in sacrifice (Gen. 22:6; Ezra 1:9). A general knife, in contrast, alludes to the instrument used to cut a child's umbilical cord at birth and to circumcise a male child (Josh. 5:2; Ezek. 16:4).

115 See Merlano, Vasari a Bosco Marengo, 9-11; and Härb, The Drawings of Giorgio Vasari, 285 n. 357, for illustration and literary references to these commissions.

116 See Cheney, "Vasari and Naples," 48-126; Merlano, Vasari a Bosco Marengo, 9-11; and Härb, The Drawings of Giorgio Vasari, 285 n. 357, for illustration and literary references to these commissions.

117 See C. S. Lewis, Mere Christianity (New York: HarperCollins, 1952), 51-52; and Gary Habermas, The Case for the Resurrection of Jesus (Grand Rapids, MI: Kregel, 2004), on the meaning of Christ's Resurrection. Special gratitude to my brother, Daniele De Girolami, MD, for providing these sources.
} 
provide guidance and the basis for a Christian life. In this context, Vasari was visually abiding by the Roman Christian metaphorical concept of the Transubstantiation. Whether or not he was fully aware of the complex doctrinal concepts and debates on Christ's nature (divine or human or both) and the presence of the Holy Spirit in the transformation of the physical and spiritual substance in the offering of the bread and wine during the performance of the Mass (disputed during the Council of Trent in 1547), no doubt he did not ignore them, since he visualized the mystery of the Eucharistic thanksgiving in his painting. ${ }^{118}$

From the sixth century until the end of the sixteenth, there was in the Roman Christian rite only one Eucharistic prayer, known as the Canon of the Mass, where an epiclesis (Greek term for invocation) of the Holy Spirit was recited before and after consecration of the host, symbolically the body of Christ. This invocation or petition asked the Father to send the Holy Spirit upon the bread and wine to transform them into the body and blood of Christ, ${ }^{119}$ as noted in Thomas Aquinas's Eucharistic hymn Pange lingua gloriosi corporis mysterium [Sing, my tongue on the mystery of the glorious Body]. ${ }^{120}$ The invitation to the Holy Spirit to partake of the presence of the thanksgiving blessings was noted already in the writings of Saint Paul (1 Cor. 3:16; 6:17; and Gal. 5:22). ${ }^{121}$ The Holy Spirit occupied a central place in Christian life because through its granting of spiritual

118 See Bosch, "Orthodoxy and Heterodoxy in Agnolo Bronzino's Painting of Bartolomeo and Lucrezia Panciatichi," 68-81, on the references on the Transubstantiation. See Reverend H. J. Schroeder, trans., The Canons and Decrees of the Council of Trent (Charlotte, NC: Tan, 1911), 72-75, on the Church's position on Transubstantiation. This doctrine maintains that at the consecration of the Mass, a conversion of the substance occurs from the Eucharistic elements of bread and wine into the body and blood of Christ, leaving only the appearance of bread and wine. In contrast, the Reformation believed in the precept of consubstantiation, which maintains that Christ's body and blood coexist with the bread and the wine. See also David Pietrusza, ed., Sursum Corda: Documents and Readings on the Traditional Latin Mass From the Council of Trent to Benedict XVI's Motu Propio (USA: Createspace, 2008), 5-59, on the Council of Trent's ruling on the Eucharist and Transubstantiation, especially 39-44, for the teaching on Transubstantiation. See also Bernard McGinn, John Meyendoff, and Jean Leclercq, Christian Spirituality, 2 vols. (New York: Crossroad, 1988), 1:240-251, on Christ and the Holy Spirit in the eukharistia (Christ's thanksgiving) and on Christ's nature; and 2:282, on Luther's position on the Last Supper and the offering of the bread and wine and the denial of the Transubstantiation.

119 See McGinn, Meyendoff, and Leclercq, Christian Spirituality, 1:245: "that by the priest's invocation, by the coming of the Most Holy Spirit, the body and blood of Christ are mystically and invisible made present ... not because body ceased to be a body, but because it remains so and is preserved as body." For the Lutheran antithetical position, see 282. See also M.C. Howatson, ed., The Oxford Companion to Classical Literature (Oxford: Oxford University Press, 1989), 463 and 478, for the history and theological significance of the epiclesis, a highly controversial Christian issue.

${ }^{120}$ See n. 5; and Härb, The Drawings of Giorgio Vasari, 284-285, for recent literature on the Vasari's Last Supper.

121 After his reading of Plato and Aristotle, Cicero identified the natural virtues (Prudence, Justice, Temperance and Fortitude) in De natura decorum, III.xv, and in De officiis, I.xliiif. The word virtue derives from the Latin word virtus (manliness), and the Greek word areté [excellence] is an ethical signification of the value of the soul and actions of the individual. During ancient times, these virtues were four in number (Wisdom, Courage, Temperance, and Justice). Socrates began the discussion by identifying virtue with knowledge and holding that one could not know the good without first willing it. Plato restated Socrates' notions (Republic, IV, 427-435) and contributed an extensive analysis on the four virtues. Aristotle (Nicomachean Ethics, VI.5; V.1; III.7 and 10) distinguished between intellectual and moral virtues, relating Plato's four virtues to the theoretical (spiritual) life and practical (natural) life. During the early Christian period and the Middle Ages, the four natural virtues were thoroughly studied by the Church Fathers and Scholastics; for example, by Saint Ambrose (De officiis ministrorum), who introduced the term cardinal virtues after reading Cicero's writings on Plato's classification; by Saint Augustine (De natura e gratia), who maintained that love and the cardinal virtues of Plato were fundamental sources for the Christian life; and by Saint Thomas Aquinas (Summa theologica, II, II), who studied their relationships to each other and to the concept of grace. On this topic, see John A. Oesterle, St. Thomas Aquinas: Treatise on the Virtues (Notre Dame, IN: University of Notre Dame Press, 1966), 108-118, on the cardinal virtues; and 118-124, on the theological virtues. See also the excellent study by O'Reilly, Studies in The Iconography of The Virtues and Vices in the Middle Ages; Mary Daly, "Faith, Hope and Charity," in Dictionary of the History of Ideas, ed. Phillip P. Wiener, 5 vols. (New York: Scribner, 1973), 4:209-212, for a discussion on the interrelationship between the concepts of the theological virtues from Plato to the writings of the Church Fathers; and Helen F. North, "The Iconography of the Cardinal Virtues," in Dictionary of the History of Ideas, 4:371-378, for a historical study on the four natural virtues. 
fruits and gifts, the faithful could achieve moral purity and holiness. ${ }^{122}$

When the nuns of Le Murate entered their refectory and saw the majestic image of Christ's Last Supper, they saw their invitation to Christ's supper table. Therefore they re-enacted Christ's thanksgiving blessing with the Eucharistic prayer by saying grace before their meal: "Bless us, O Lord, and these, Thy gifts, which we are about to receive from Thy bounty through Christ, our Lord. Amen." 233 Thereby they partook of Christ's eternal blessings at every meal in their refectory at Le Murate.

\section{References}

Alciato, A. (1531). Emblematun liber [Book on Emblems]. Augsburg: Heinrich Steyner.

Alotto, M. (2009). Contributi documentari su Giorgio Vasari a Camaldoli [Documentaries' contributions on Giorgio Vasari at Camldoli]. Arte Cristiana, 855, 469-474.

Archivio di Stato di Bologna, Libri delle Fabbriche: Olivetani in San Michele in Bosco [Bologna's State Archives, Books on structures: Olivetan of San Michael in Bosco] Book 4; Carte 5:38; 5:39.

Archivio di Stato di Napoli. "Monasterio di Monteoliveto" [Naples' State Archives "The Monastery of Monteoliveto"] vols. 5504, 5529, 5532, 6033, and 6035.

Barocchi, P. (1964). Vasari Pittore. Milan: Club del Libro.

Bauscher, D. (2013). The original Aramaic new testament in plain English with psalms \& proverbs (8th ed. with notes). Lulu.com: Glenn David Bauscher.

Bellucci, R. M. C., \& Cecilia, F. (forthcoming). Dall'alluvione alla rinascita: il restauro dell'Ultima Cena di Giorgio Vasari. Florence: Edifir.

Bettarini, R., \& Paola, B. (Eds.). (1996-1998). Giorgio Vasari, Le vite de più eccellenti pittori, scultori e architettori: nelle redazioni del 1550 e 1568 (6 vols.). Florence: Sansoni.

Bible American Standard Version (ASV) (public domain).

Blumenthal, A. R. et al. (2001). Cosimo Rosselli: Painter of the Sistine Chapel. Winter Park: Cornell Fine Arts Museum.

Bosch, Lynette M. F. (2014). Orthodoxy and Heterodoxy in Agnolo Bronzino's painting of Bartolomeo and Lucrezia Panciatichi. In Liana De Girolami Cheney (Ed.), Agnolo Bronzino: Florentine Muse (pp. 35-134). Washington, DC: New Academia.

Bullinger, E. W. (2011). Numbers in scripture: Its supernatural design and spiritual significance. Grand Rapids, MI: Kregel.

Burton, R. (Ed.). (1989). Prudentius, Psychomachia. Bryn Mawr, PA: Bryn Mawr Commentaries.

Caponetto, S. (1999). The protestant reformation in Sixteenth-Century Italy. Kirksville, MO: Truman State University Press.

Carroll, E. A. (1967). Lappoli, Alfani, Vasari, and Rosso Fiorentino. The Art Bulletin, 49, 297-304.

Cecchi, A. (1998). Giorgio Vasari's collection of paintings: Its provenance and its fate. In P. Jacks (Ed.), Vasari's Florence: Artists and literati and the medicean court. Cambridge: Cambridge University Press.

Cheney, Liana De Girolami. (1994). Vasari and Naples: The Monteoliveto order. Papers in Art History, 5, 48-126.

Cheney, Liana De Girolami. (1995). Giorgio Vasari's Sala dei Cento Giorni: A Farnese celebration. Exploration in Renaissance Culture, 21, 121-151. Reissued for the 40th Anniversary of ERC Publication (Spring 2015).

Cheney, Liana De Girolami. (2016). Giorgio Vasari and mannerist architecture: A marriage of beauty and function in urban spaces. Journal of Literature and Art Studies, 6(10), 1150-1171.

Cheney, Liana De Girolami. (2017). Giorgio Vasari's fine arts from the Vite of 1550: The splendor of creativity and design. Journal of Literature and Art Studies, 7(2), 1-40.

Ciardi, R. P., \& Alberto, M. (1991). Rosso Fiorentino. Florence: Cantini.

Colds, C. (1974). Queries on Last Suppers and their Refectories. In Trinkaus (Ed.), The pursuit of holiness in late medieval and renaissance religion (pp. 403-407). Leiden: Brill.

122 The Holy Spirit's gifts are the virtues of Benignity or Mercy, Chastity, Continence or Poverty, Faith, Goodness, Joy or Abundance, Longanimity or Patience, Love or Charity, Meekness or Obedience Modesty or Pudicity, Peace or Concord, and Temperance. See Saint Thomas Aquinas, Summa theologica, II, I, q. 70, a. 3.

123 The nuns of Le Murate probably recited a similar prayer of saving grace before each meal. In some convents, silence was observed during the meal while a literate nun read aloud religious passages from the Bible and psalter. See Strocchia, Nuns and Nunneries in Renaissance Florence, 204, n. 75. See also Catherine E. King, Renaissance Women Patrons, Wives and Widows in Italy, 1300-1550 (Manchester: Manchester University Press, 1998), 201, on laywomen saying grace at their meal as well. 
Colonelli, L., \& Michael, S. (2015). The table of the Lord: The Last Supper. What did Jesus and the Apostles eat and what have painters over the centuries given them to eat. Pictures, recipes, heaven and hell. Florence: Edition Clichy.

Conforti, C. (1993). Giorgio Vasari architetto. Milan: Electa.

Conti, A. (1982). La fabbrica, la chiesa, l'appartamento dei Signori. In Lo Spedale Serristori di Figline-Documenti e arredi, exh. cat. [The building, the church, the apartment of the Nobles in the Documents of the Hospital of Serristori of Figline]. Florence: Opus Libri.

Daly, M. (1973). Faith, hope and charity. In Phillip P. Wiener (Ed.), Dictionary of the history of ideas (5 vols.) (pp. 209-212). New York: Scribner

de Castris, Leon. (1981). Napoli 1544: Vasari e Monteolivelo. Bolletino d'Arte, 66, 59-88.

de Tervarent, G. (1977). Attributs et Symboles dans L'Art Profane [Attributes and Symbols in Profane Art]. Geneva: Droz.

Deitz, P. (2016). 50 years after the flood. The New York Times, 6, 18-21.

del Vita, A. (1938). II Libro delle Ricordanze di Giorgio Vasari. Arezzo: Fratelli Zelli.

Ditchfield, S. (1995). Liturgy, sanctity and the history of the Tridentine in Italy. Cambridge: Cambridge University Press.

Dow, D. N. (1988). Apostolic iconography and Florentine confraternities in the age of reform. Burlington, VT: Ashgate.

Dunlop, A. (2015). Andrea del Castagno and the limits of painting. New York: Harvey Miller.

Fehl, P. (1961). Veronese and inquisition: A study on the subject matter of the so-called Feast in the House of Levi, files. Gazette des Beaux-Arts, 6(158), 348-354.

Fehl, P. (1981). Veronese's Decorum: Notes on The Marriage at Cana. In Mosche Barash et al. (Eds.), Art the ape of nature (pp. 341-365). New York: Harry H. Abrams.

Ferguson, G. (1961). Signs and symbols in Christian art. London: Oxford University Press.

Ferrari, G. (1957). Early Roman monasteries. Rome: Pontificio Istituto di Archeologia Cristiana.

Fratini, D. (2007). Un profilo di Arezzo nel ‘500: Guillaume de Marcillat, Giovann’ Antonio Lappoli e Niccolò Soggi nelle "Vite” del Vasari. In Arezzo e Vasari (Ed.), Antonino Caleca (pp. 67-83). [An Aretine Profile in the "500: Guillaume de Marcillat, Giovann" Antonio Lappoli and Niccolo Sogni in the Lives of Vasari]. Foligno: Cartei \& Bianchi.

Freedberg, S. J. (1963). Andrea Del Sarto (2 vols.). Cambridge, MA: Belknap Press of Harvard University Press.

Freedberg, S. J. (1993). Painting in Italy, 1500-1600, Pelican history of art. New Haven: Yale University Press.

Frey, K. ( 1923). Der literarische Nachlass Giorgio Vasaris (2 vols.). Munich: George Müller.

Getscher, R. H. (2003). An annotated and illustrated version of Giorgio Vasari's history of Italian and Northern prints from his lives of the artists (1550 and 1568). New York: Mellen.

Gilbert, G. (1974). Last Suppers and their refectories. In C. Trinkaus (Ed.), The pursuit of holiness in Late Medieval and renaissance religion (pp. 371-402). Leiden: Brill.

Goffen, R. (1986). Friar Sixtus IV and the Sistine Chapel. Renaissance Quarterly, 39(2), 218-262.

Grabar, A. (1954). Thrônes épiscopaux du XI et XIIe siècle en Italie méridionale. [Episcopal thrones of XI and XII centuries in southern Italay]. Wallraf-Richartz Jahrbuch, 16, 8-10.

Gregory, S. (2012). Vasari and the renaissance print. Burlington, VT: Ashgate.

Habermas, G. (2004). The case for the resurrection of Jesus. Grand Rapids, MI: Kregel.

Hall, J. (1974). Dictionary of subjects and symbols in art. New York: Harper and Row.

Härb, F. (2015). The drawings of Giorgio Vasari (1511-1574). Rome: Ugo Bozzi.

Härbison, C. (1976). Dürer and the reformation: The problem of the re-dating of the St. Philip engraving. Art Bulletin, $58(3)$, 368.

Harpraph, R. (1977). Italianische Zeichnungen des 16. Jahrhunderdts aus eigenem Besitz (pp. 159-160). Munich: Staatliche Graphische Sammlung.

Harpraph, R. (1981). L’Ultima Cena. In Laura Corti et al (Ed.), Giorgio Vasari. Principi, letterati e artisti nelle carte di Giorgio Vasari. Pittura vasariana dal 1532 al 1554 (pp. 63-64). Florence: Edam.

Helgot, P., \& Bullot, M. (1773-39). Ordini Religiosi [Religious Orders] 8 vols. Lucca: np, vol. 7 on Naples.

Hermann-Fiore, K. (1976). Sui rapporti tra l'opera artistica del Vasari e del Dürer. In Atti del Convegno Il Vasari Storiografo e Artista [On the relation between the art of Vasari and Dürer. In the Conference's Proceedings on Vasari's Historian and Artist] (Florence: Istituto nazionale di studi sul Rinascimento, 701-715).

Howatson, M. C. (Ed.) (1989). The Oxford Companion to Classical Literature. Oxford: Oxford University Press.

Johnston, R. D. (1999). Numbers in the Bible: God's unique design in biblical numbers. Grand Rapids, MI: Kregel.

King, C. E. (1998). Renaissance women patrons, wives and widows in Italy, 1300-1550. Manchester: Manchester University Press. 
Kliemann, J. (1981). Vasari, Pollastra e l'allegoria della "Concezione" [Vasari, Pollastra and the Allegory of the Conception] in Corti, Giorgio Vasari. Principi, letterati e artisti nelle carte di Giorgio Vasari [Giorgio Vasari, Princes, letterari, and artists in the letters of Giorgio Vasari] Florence: Edam, 103-105.

Ladis, A. (1983). Taddeo Gaddi: Critical Reappraisal and Catalogue Raisonne. Saint Louis: University of Missouri Press.

Lehman, H. (2006). The language of God in prophecy. Elmwood Park, IL: Pillar of Enoch Ministry.

Lewis, C. S. (1952). Mere Christianity. New York: Harper Collins.

Lotz, W., \& Deborah, H. (1974/1995). Architecture in Italy-1500-1600. New Haven: Yale University Press.

Lowe, K. J. P. (1990). Female strategies for success in a male-oriented world: The Benedictine Convent of Le Murate in Florence in the fifteenth and early sixteenth century. Studies in Church History, 27, 209-221, 218.

Luria, K. P. (2001). "Popular Catholicism" and the Catholic reformation. In Kathleen M. Comerford and Hilmar M. Pabel (Eds.), Early Modern Catholicism: Essays in Honor of John W. O'Malley (pp. 114-116). Toronto: The University of Toronto Press.

Maietta, I. (2011). Vasari a Napoli: I Dipinti della sagrestia di San Giovanni a Carbonara: il restauro, gli studi, le indagini [Vasari and Naples: The painting in the sacresty of San Giovanni a Carbonara: Restoration, studies and investigations]. Naples: Paparo.

McGinn, B., Meyendoff, J., \& Leclercq, J. (1988). Christian Spirituality, 2 vols. New York: Crossroad.

Merlano, B. (2010). Vasari a Bosco Marengo: Studi per il restauro delle tavole Vasariane in Santa Croce [Vasari at Bosco Marengo: Studies on the restoration of Vasari's panels in Santa Croce]. Savignone: SAGEP.

Metford, J. C. J. (1983). A Dictionary of Christian Lore and Legend. London: Thames and Hudson.

Michael H. (May 2012). The Significance of Numbers in Scripture. http://www.agapebiblestudy.com/documents/the\%20significance\%20of\%20numbers\%20in\%20scripture.htm I

Milanesi, G. (Ed.). (1970-1974). Giorgio Vasari, Le vite de più eccellenti pittori, scultori e architettori [Giorgio Vasari's lives of the most excellent painters, sculptors and architects] (9 vols.). Florence: Sansoni.

Natali, A., \& Cecchi, A. (1989). Andrea del Sarto. Florence: Cantini.

Nelson, J. (Ed.). (1999). Suor Plautilla Nelli (1523-1588): The First Woman Painter of Florence. Florence: Edizione Cadmo.

Nocentini, S. (2013). Giorgio Vasari, Ultima Cena, entry in Arte a Figline: Da Paolo Uccello a Vasari (pp. 140-142). Nicoletta Pons (Ed.) [Giorgio Vassri's Last Supper, entry in Art at Figline: From Paolo Uccello to Vasari]. Florence: Edifir.

North, H. F. (1973). The iconography of the Cardinal virtues. In Phillip P. Wiener (Ed.), Dictionary of the history of ideas (5 vols.) (pp. 371-378). New York: Scribner.

O'Reilly, J. (1988). Studies in the iconography of the virtues and vices in the middle ages. New York: Garland.

Oesterle, J. (1966). St. Thomas Aquinas: Treatise on the virtues. Notre Dame, IN: University of Notre Dame Press.

Panofsky, E. (1952). The life and art of Albrecht Dürer. Princeton: Princeton University Press.

Paolucci, A. (1980). Le Opere d'Arte [The Art Works]. In Arnaldo d'Addario (Ed.), La Comunità Cristiana Fliorentina e Toscana nella Dialettica Religiosa nel Cinquecento (pp. 197-204). Florence: Becocci.

Parma Armani, E. (1980). Fonti per il 'Convito per le nozze di Ester e Assuero' di Giorgio Vasari in Arezzo [Documents for the Feast of the Esther and Ahasuerus of Giorgio Vasari in Arezzo]. Studi di storia delle arti, 3, 61-75.

Pietrusza, D. (Ed.). (2008). Sursum Corda: Documents and readings on the traditional Latin mass from the council of Trent to Benedict XVI's Motu Propio. USA: Createspace.

Pilliod, E. (2001). Pontormo, Bronzino, Allori. A genealogy of Florentine art. New Haven and London: Yale University Press.

Pitre, B. (2015). Jesus and the Last Supper. Grand Rapids, MI: William B. Eerdmans.

Price, D. (1996). Albrecht Dürer's "Last Supper" (1523) and the "Septembertestament”. In Zeitschrift für Kunstgeschichte 9. Bd., H. 4, 578-584.

Scarpini di Asciano, Modersto. (1952). I Monaci Benedettini di Monte Oliveto [The Benedictine Monks of Monte Oliveto]. Alessandria: L'Ulivo.

Schiller, G. (1971). Iconography of Christian art (2 vols.). Greenwich, CT: New York Graphic Society.

Schroeder, H. J. (Trans.). (1911). The canons and decrees of the council of Trent. Charlotte, NC: Tan.

Shawn, T. (2015). The virtues and vices in the arts: A sourcebook. Eugene, OR: Cascade.

Steinberg, L. (2001). Leonardo's Incessant Last Supper. New York: Zone. Originally printed in The Art Quarterly, 36(4), 297-410.

Strazzullo, F. (1963-1964). La fondazione di Monteoliveto in Napoli. Napoli nobilissima, 3, 103-111.

Strocchia, S. T. (2010). Nuns and nunneries in renaissance Florence. Baltimore: Johns Hopkins University Press.

Tartuferi, A., \& D'Arelli, F. (2014). L'Arte di Francesco: Capolavori d'arte italiana e terre d'Asia, dal XIII al XV secolo [The art 
of Francesco works of Italian art and Asian lands]. Milan: Giunti.

Verdon, T. G. (1984). Monasticism and the arts. Syracuse, NY: Syracuse University Press.

Vertova, L. ( 1965). I Cenacoli Fiorentini [The Florentine Last Suppers]. Turin: Edizione Radiotelevisione Italiana.

Vinassa De Regny, P. (1988). Dante e il simbolismo pitagorico [Dante and Pythagoras' Symbolism]. Genoa: Fratelli Melita.

Viviani Della Robbia, E. (1952). Note e notizie sul Cenacolo del Vasari per il monastero delle Murate di Fiorenza. In Studi

Vasariani (pp. 220-226) [Notes and News on Vasari's Last Supper for the Monastery of Le Murate in Florence]. Florence: Sansoni.

Weddle, S. (2003). "Women in Wolves" Mouths': Nuns' reputations, enclosure and architecture at the Convent of Le Murate in

Florence. In H. Hills (Ed.), Architecture and the politics of gender in early modern Europe (pp. 115-129). Aldershot: Ashgate.

Weiss, R. (1961). A note on the so-called "Fides Simulacrum". Journal of the Warburg and Courtauld Institutes, $24,128$.

Wharton, E. (1983). The date and significance of the Cathedral of Canosa in Apulia, South Italy. Dumbarton Oaks Papers, 37, 79-90.

Wilson, R. F. (2006). Early Christian symbols in the Catacombs.

Retrieved from http://www.jesuswalk.com/christian-symbols/early-christian-symbols.htm

Zeri, F. (1976). Italian paintings in the Walters Art Gallery with Notes by Elisabeth G. Packard and Ursula E. McCracken. Baltimore: Walters Art Gallery.

Zeri, F. (1998). Ultima Cena of Leonardo da Vinci. Milan: Rizzoli. 